\title{
An Analysis of Stream Culvert Fish Passage on the Navy Railroad Line between Bremerton and Shelton, Washington
}

C.W. May

M.C. Miller

J.A. Southard

Battelle Marine Sciences Laboratory

Sequim, Washington

September 2004

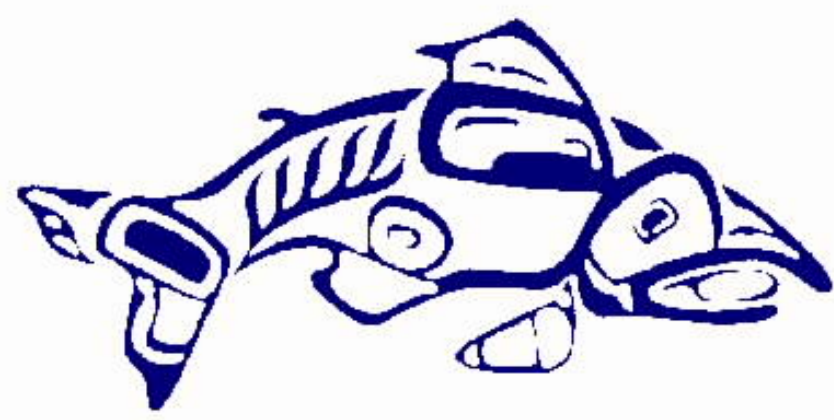

Prepared for:

Puget Sound Naval Shipyard and Intermediate Maintenance Facility

under a Related Services Agreement with the U.S. Department of Energy under Contract DE-AC06-76RLO 1830 


\title{
DISCLAIMER
}

This report was prepared as an account of work sponsored by an agency of the United States Government. Neither the United States Government nor any agency thereof, nor Battelle Memorial Institute, nor any of their employees, makes any warranty, express or implied, or assumes any legal liability or responsibility for the accuracy, completeness, or usefulness of any information, apparatus, product, or process disclosed, or represents that its use would not infringe privately owned rights. Reference herein to any specific commercial product, process, or service by trade name, trademark, manufacturer, or otherwise does not necessarily constitute or imply its endorsement, recommendation, or favoring by the United States Government or any agency thereof, or Battelle Memorial Institute. The views and opinions of authors expressed herein do not necessarily state or reflect those of the United States Government or any agency thereof.

\author{
PACIFIC NORTHWEST NATIONAL LABORATORY \\ operated by \\ BATTELLE \\ for the \\ UNITED STATES DEPARTMENT OF ENERGY \\ under Contract DE-AC06-76RL01830 \\ Printed in the United States of America \\ Available to DOE and DOE contractors from the \\ Office of Scientific and Technical Information, \\ P.O. Box 62, Oak Ridge, TN 37831-0062; \\ ph: (865) 576-8401 \\ fax: (865) 576-5728 \\ email: reports@adonis.osti.gov
}

\author{
Available to the public from the National Technical Information Service, \\ U.S. Department of Commerce, 5285 Port Royal Rd., Springfield, VA 22161 \\ ph: (800) 553-6847$$
\text { fax: (703) 605-6900 }
$$ \\ email: orders@ntis.fedworld.gov \\ online ordering: http://www.ntis.gov/ordering.htm
}




\section{An Analysis of Stream Culvert Fish Passage on the Navy Railroad Line between Bremerton and Shelton, Washington}

Christopher W. May

Martin C. Miller

John A. Southard

Battelle Marine Sciences Laboratory

Sequim, Washington

February 2004

Prepared for

Puget Sound Naval Shipyard and

Intermediate Maintenance Facility

under a Related Services Agreement

with the U.S. Department of Energy

Contract DE-AC06-76RL0 1830

Pacific Northwest National Laboratory

Richland, Washington 


\section{EXECUTIVE SUMMARY}

This report describes and assesses salmonid habitat along the Navy railroad service line running between Shelton and Bremerton. This report does not assess salmonid habitat along the railroad service line running from Bremerton to Silverdale. The Navy railroad was constructed in the 1940's and is used by the Navy to transfer freight to its facilities. It is also used by commercial clients to ship service items and bulk cargo for municipalities along portions of the route. Culverts of various sizes and configurations convey streams and stormwater runoff under the railroad line. These allow transfer of water and, in some cases allow for passage of juvenile and adult salmon into waters upstream of the culverts.

Salmonid Habitat Limiting Factors Reports for Water Resource Inventory Areas (WRIA) 14 (KennedyGoldsborough Basin) and 15 (Kitsap County) identified a total of eleven culverts along the railroad as unknown or known fish-passage barriers. The Navy contracted Battelle Marine Sciences Laboratory to locate and describe known and potential fish-passage barrier culverts, assess the fish passage ability of each culvert, and prepare a technical report of the findings with recommendations for corrections including priority index scores.

As part of this project, the 11 culverts identified by WRIA 14 and WRIA 15 were assessed, and an additional 10 culverts along a 34-mile reach (Shelton to Bremerton) of the railroad were surveyed to evaluate their function and ability to allow salmon to utilize the streams. The culverts and attached watersheds were evaluated using criteria developed by the Washington Department of Fish and Wildlife to assign a Priority Index (PI) to barriers present on each fish-bearing stream. The PI is a relative numeric rating indicator, assigned using consistent criteria related to the degree of potential habitat gained by removing barriers and improving the function of the watershed.

Of the 21 culverts evaluated, seven (7) were found to be fish-passage barriers and twelve (12) were assessed as passable based on WDFW criteria. PI scores were obtained for all barrier culverts and several of the passable culvertsCorrective action will be taken based on any PI scores and structural engineering factors related to RR operations. Several of the streams and culverts had previously been evaluated for structural integrity and function and have been scheduled for repair. A narrative indicating the condition of the culverts has been prepared as well as a table indicating the PI scores and a summary of recommendations for action for each culvert. 


\section{ACRONYMS}

$\begin{array}{ll}\text { CMP } & \text { corrugated metal piping } \\ \text { CMZ } & \text { channel migration zone } \\ \text { GIS } & \text { geographical information system } \\ \text { GPS } & \text { global positioning system } \\ \text { HCSEG } & \text { Hood Canal Salmon Enhancement Group } \\ \text { LFA } & \text { Limiting Factors Assessment } \\ \text { LWD } & \text { large woody debris } \\ \text { MP } & \text { milepost } \\ \text { PI } & \text { Priority Index } \\ \text { PNNL } & \text { Pacific Northwest National Laboratory } \\ \text { PSNS \& IMF } & \text { Puget Sound Naval Shipyard and Intermediate Maintenance Facility } \\ \text { SPSSEG } & \text { South Puget Sound Salmon Enhancement Group } \\ \text { WAC } & \text { Washington Administrative Code } \\ \text { WA-DNR } & \text { Washington Department of Natural Resources } \\ \text { WCC } & \text { Washington Conservation Commission } \\ \text { WDFW } & \text { Washington Department of Fish and Wildlife } \\ \text { WRIA } & \text { Water Resources Inventory Areas } \\ \text { WSDOT } & \text { Washington State Department of Transportation }\end{array}$




\section{CONTENTS}

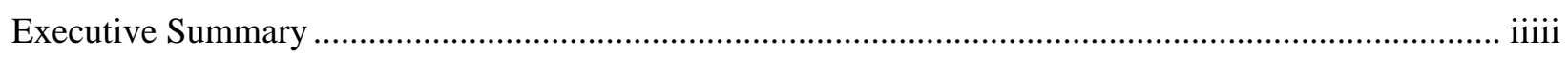

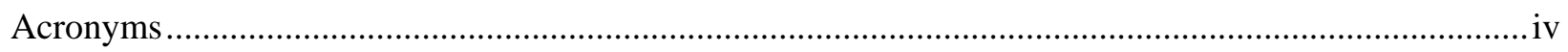

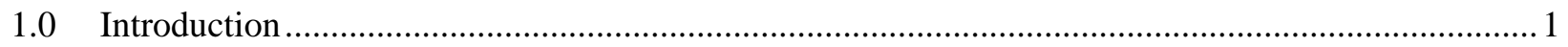

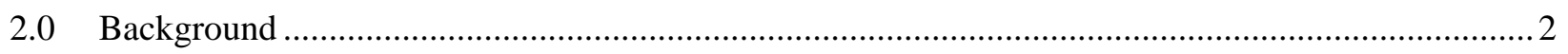

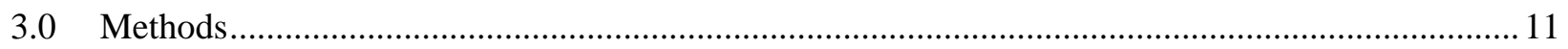

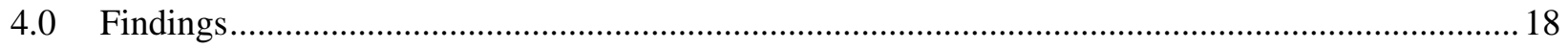

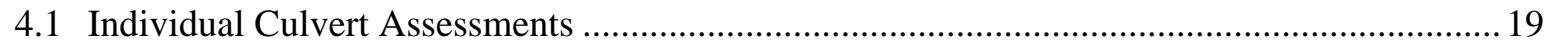

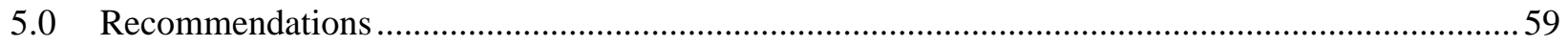

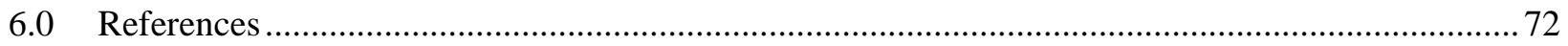

\section{FIGURES}

1. Typical problems at culvert exit that can cause fish passage barriers................................................ 4

2. Typical problems with culverts that can cause fish passage barriers................................................ 5

3. Typical problems with culverts that can cause fish passage barriers ............................................... 6

4. Typical alignment problems with culverts that can cause fish passage barriers ............................... 7

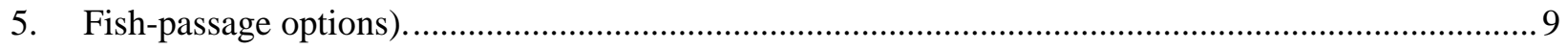

6. Overview of Fish-Passage Barrier Assessment Process. ...................................................................12

7. Overview of Level-A Fish-Passage Barrier Assessment Process....................................................... 13

8. Overview of Level B Fish-Passage Barrier Assessment Process. ...................................................... 16

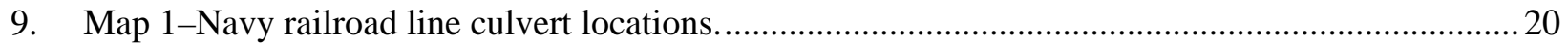

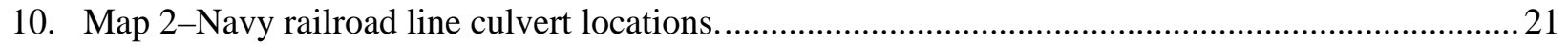

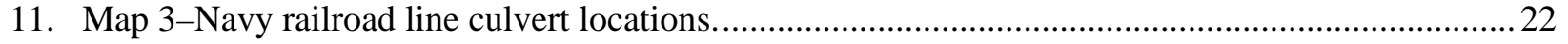

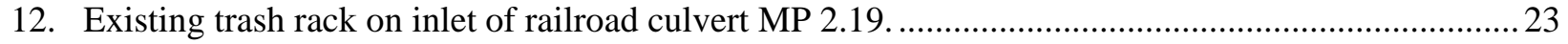

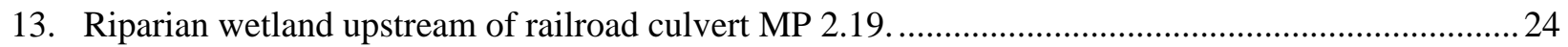

14. Johns Creek box culvert and fishway, railroad MP 3.79............................................................... 25

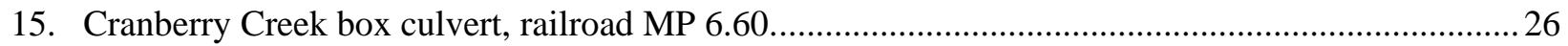

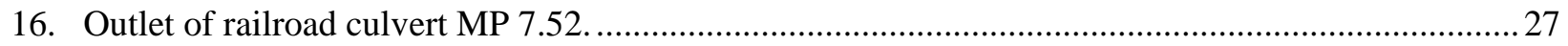

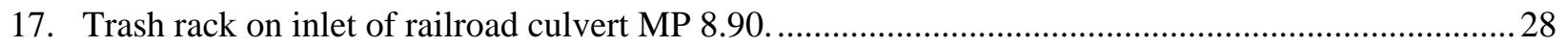

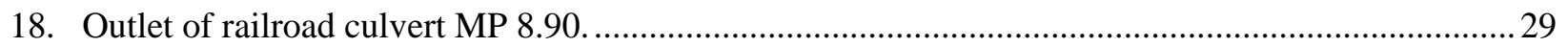

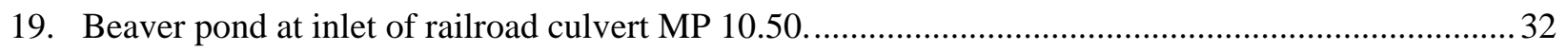

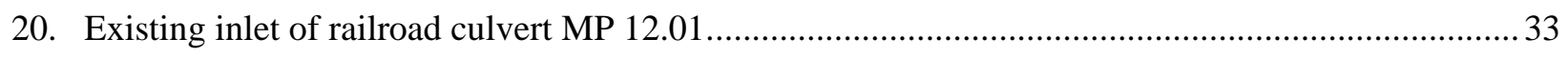

Railroad Culvert Report $\quad$ v

Puget Sound Naval Shipyard and Intermediate Maintenance Facility 


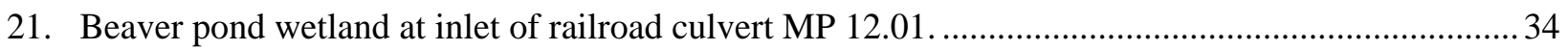

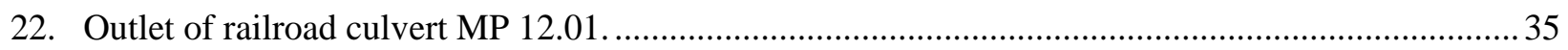

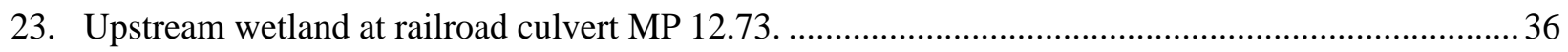

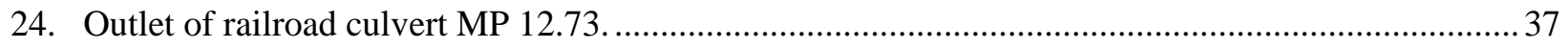

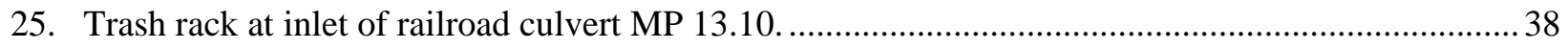

26. Upstream abandoned beaver pond at railroad culvert MP 13.10 .................................................. 39

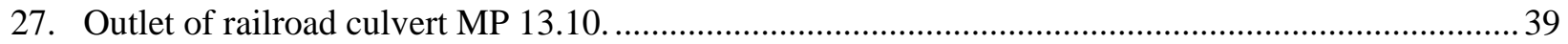

28. Beaver pond wetland at inlet of railroad culvert MP 14.89 ........................................................... 40

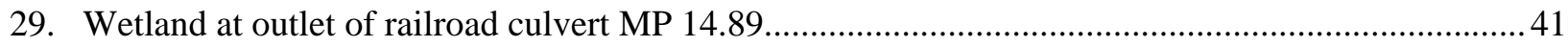

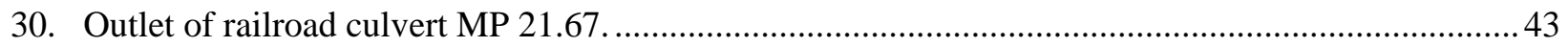

31. Falls just downstream of outlet of railroad culvert MP 21.67......................................................... 44

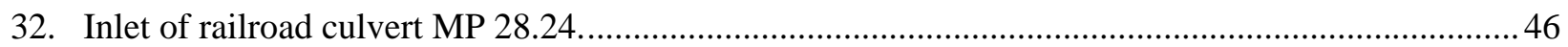

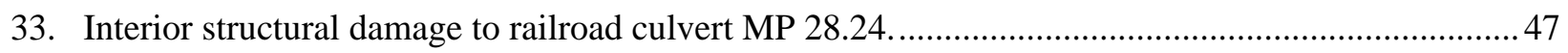

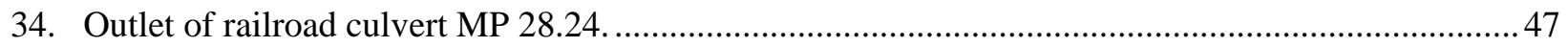

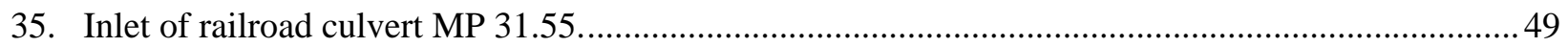

36. Instream habitat upstream of railroad culvert MP 31.55 ................................................................... 50

37. Instream habitat downstream of railroad culvert MP 32.09 ............................................................51

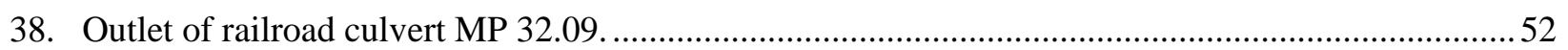

39. Instream habitat just upstream of railroad culvert MP 32.09.......................................................5

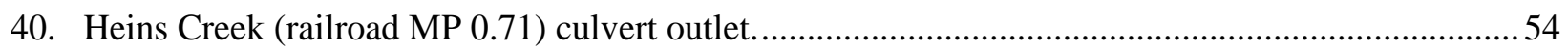

41. Upstream extension on Jarstad Creek (railroad MP 1.04) culvert. ...................................................5

42. Upstream extension on Jarstad Creek (railroad MP 1.04) culvert. ..................................................56

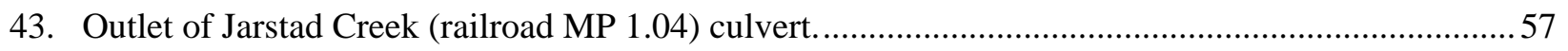

44. Instream habitat downstream of Jarstad Creek (railroad MP 1.04) culvert. ......................................58

45. Bremerton culvert downstream of Jarstad Creek (railroad MP 1.04) culvert. ...................................5 58

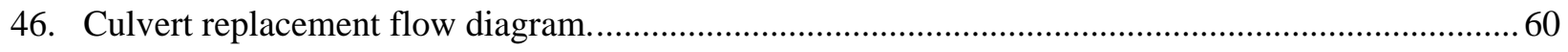

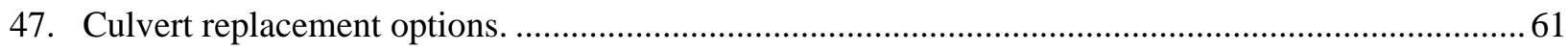

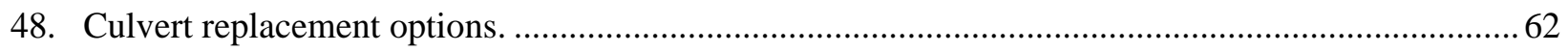

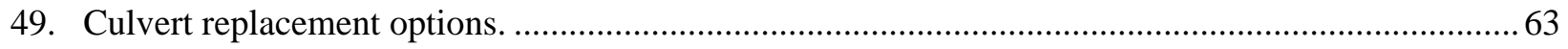

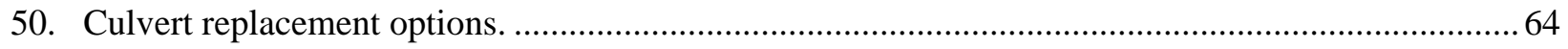

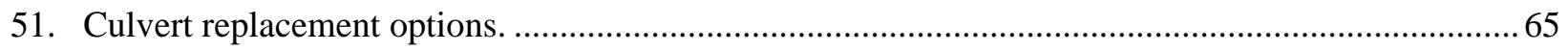

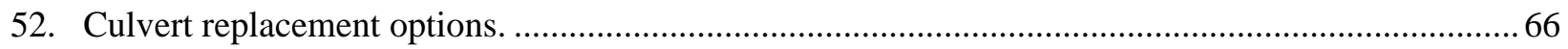

Railroad Culvert Report vi

Puget Sound Naval Shipyard and Intermediate Maintenance Facility 


\section{TABLES}

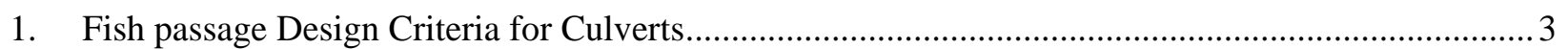

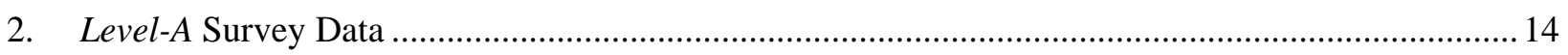

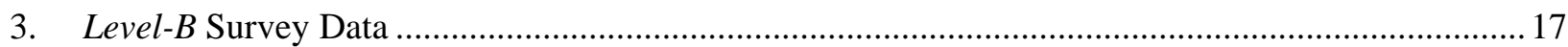

4. Summary of Navy Railroad Culvert General Information.............................................................18

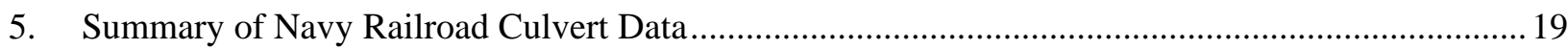

6. Navy Railroad Culvert Corrective Action Summary ........................................................................ 70 


\subsection{INTRODUCTION}

In general, culverts serve two main purposes: 1) they provide a conveyance for surface water and stormwater under a roadbed or railroad grade, and 2) they allow fish and wildlife passage under the transportation route. If designed and installed properly, a culvert can perform both purposes concurrently, under a full range of flow conditions. The culvert must be sized and sited correctly to allow downstream passage of not only water, but also stream bed-load material and large woody debris (LWD). Fish passage through culverts includes upstream migration of anadromous and resident adult salmonids during the spawning season, as well as movement (upstream or downstream) of juveniles or resident adults at various times of the year (Kahler and Quinn 1998).

There are many culverts along the Navy railroad between Shelton, Bremerton, and Silverdale. This project was initiated to evaluate the 21 culverts along the Shelton to Bremerton reach of the railroad that were identified as partial or complete fish-passage barriers in the salmonid habitat Limiting Factors Assessment (LFA) for Water Resources Inventory Areas (WRIA) 14 (WCC 2002) and 15 (WCC 2000). The culverts along the study reach were evaluated for fish passage in accordance with criteria established by the Washington Department of Fish and Wildlife (WDFW). Data collected during field surveys were used to develop priority index (PI) scores for the barriers in accordance with procedures developed and published by WDFW (2000). The PI score is a relative numeric indicator that allows a prioritization of potential corrective action to the barrier for fish passage. The PI score incorporates many factors that affect the corrective action's feasibility, including a very basic cost-benefit analysis. The higher the PI score, the greater the benefit to salmon and the higher the priority for corrective action.

The objectives of this study include:

1. Locate and describe known and potential fish passage barrier culverts along the Navy railroad (the study reach)

2. Assess the fish passage ability of each culvert using WDFW (2000) guidelines and compare observed culvert data with that of Washington Administrative Code (WAC 220-110-070) for fish passage through over-water structures

3. Prepare a technical report of the above observations and provide a PI listing of culverts, along with recommendations for the correction of fish-passage barriers.

The U.S. Navy owns approximately 48 miles of railroad line, beginning at Shelton and running to the Puget Sound Naval Shipyard and Intermediate Maintenance Facility (PSNS \& IMF) in Bremerton and to the Bangor Submarine Base in Silverdale. The railroad was built in the 1940's and is currently operated and maintained under contract with Puget Sound and Pacific Railroad. The property line varies between 25 feet to over 200 feet from the track centerline, depending on location. Administration of the railroad from Shelton to Bremerton Junction (32 miles) and from Bremerton Junction to the shipyard (4 miles) is with PSNS \& IMF, and from Bremerton Junction to the Submarine Base Bangor in Silverdale (11 miles) is with the submarine base.

In addition to serving the naval facilities, the railroad hauls freight for several commercial clients. Cargo includes utility poles at Bayshore, propane at Belfair and Chico, and solid waste at Belfair. Any construction proposed for the railroad must take into account the potential effect on the railroad customers, including the Navy and commercial clients. This effect could vary, depending on the location of the proposed construction (i.e., any work proposed on the Bremerton Branch would only effect PSNS \& IMF). As an example, in 2002, two culverts near Allyn were replaced with a bridge over Sherwood Creek. The railroad track was scheduled to be out of service for 7 days, and all customers were prepared for the gap in rail service. Contingency plans in case the track could not be placed back in service within 
7 days assigned a penalty cost of $\$ 10,000$ per day just to accommodate the solid waste needs. Therefore, any work between Milepost (MP) 0 and 29 must take into account potential delay costs to customers. All construction that might delay trains also requires advance approval by the pertinent Navy commands.

\subsection{BACKGROUND}

In fish-bearing watersheds, culverts may pose a significant obstacle to migration into preferred seasonal habitat areas. A culvert could be a complete barrier to all species of fish, adult and juvenile, under all flow conditions; a partial barrier to adult or juvenile fish; and/or a temporal barrier to adult or juvenile fish under specific flow conditions. Most culverts that are fish-passage barriers have been improperly designed, installed, and/or maintained. In addition, upstream development subsequent to culvert installation can create flows (water, debris, and bed load) far in excess of the capacity of the originally designed conveyance structure that could result in a blockage of fish passage.

A barrier to fish passage is defined as any physical instream feature that causes excessive delay in migration or abnormal expenditure of energy during any life-stage movements (Evans and Johnston 1980). Barriers can be natural or artificial. The most common manmade fish-passage barriers found in the Pacific Northwest are road culverts. In 1999, the WDFW estimated that over 2000 culverts in Washington State were significant barriers to salmonids and that over 3000 miles of habitat have been lost as a result of these problem culverts. Restoring the habitat function of these culverts is a high priority in Washington.

For a fish on an upstream migration to successfully negotiate a culvert, it must be able to enter the culvert barrel, traverse the length of the barrel, exit at the upstream end, and proceed to the first resting area. Fish entrance to the culvert may be restricted by obstructions at the entrance, excessive outlet velocity, or perch height. Passage through the culvert barrel may be restricted by excessive barrel velocity or inadequate water depth. Successful exit of the culvert may also be restricted by excessive inlet velocity. Excessive water velocity in culverts can also have a significant impact on the stream channel downstream of the culvert. High flows can cause streambank erosion and channel incision, resulting in a vertical barrier at the downstream end of the culvert.

Excessive water velocity is a common factor in many situations (Table 1). Water velocity within a culvert is a function of the cross-sectional area, slope, and roughness of the culvert, as well as stream discharge. Culvert roughness is the most readily manipulated factor that influences velocity. A variety of methods for increasing culvert roughness have been investigated, including baffles, corrugations, and the placement of bed-load material. Each of these methods has the common objective of producing a region (boundary layer) of lower flow velocity within the culvert that fish are able to utilize while the velocity in the remainder of the culvert exceeds the fishes' swimming ability. 
Table 1. Fish passage Design Criteria for Culverts (WDFW, 2000)

\begin{tabular}{|l|c|c|c|}
\hline Criteria & $\begin{array}{c}\text { Adult Trout } \\
>\text { 6 in. (150mm) }\end{array}$ & $\begin{array}{c}\text { Adult Pink, } \\
\text { Chum Salmon }\end{array}$ & $\begin{array}{c}\text { Adult Chinook, Coho, } \\
\text { Sockeye, Steelhead }\end{array}$ \\
\hline 1. Culvert Length (ft) & Velocity, Maximum (fps) & & \\
\hline a. $10-60$ & 4.0 & 5.0 & 6.0 \\
\hline b. $60-100$ & 4.0 & 4.0 & 5.0 \\
\hline c. $100-200$ & 3.0 & 3.0 & 4.0 \\
\hline d. $>$ 200 & 2.0 & 2.0 & 3.0 \\
\hline 2. Flow Depth Minimum (ft) & 0.8 & 0.8 & 1.0 \\
\hline 3. Hydraulic Drop, Maximum (ft) & 0.8 & 0.8 & 1.0 \\
\hline
\end{tabular}

Note: the average maximum velocity for juvenile fish passage is $1.0 \mathrm{fps}$

Typical fish-passage problems associated with culverts include the following (Figures 1, 2, 3 \& 4 provide examples):

- A lack of hydraulic roughness within the culvert

- Water velocity in culvert beyond swimming capability of fish

- An excessive drop at the culvert outlet ("perched" culverts)

- A culvert inlet velocity too high (fish unable to exit)

- Culvert inlet channel constriction, resulting in a "hydraulic jump"

- Depth and/or velocity problems within the culvert during flow extremes

- Debris accumulation and blockage at the culvert inlet

- Misaligned culvert with respect to the channel path

- A culvert that is too long (beyond the endurance of fish)

- A culvert installed at too steep a gradient (beyond capability of fish)

- Culverts with no resting pools at inlet or outlet ends

- Streambank erosion, scour, and deposition as a result of poor culvert-road fill

- Culverts that pass adults, but not juvenile fish

- Culverts not designed for all native species.

For the construction and design of road crossings that are passable to adult anadromous salmonids, as well as resident adult salmonids and juveniles of all species, it is important to first determine whether passage by those fish is necessary. The conclusion of a recent literature review (Kahler and Quinn 1998) is that resident and anadromous juveniles, as well as resident adult salmonids, are often highly mobile. Upstream movement was observed in nearly all studies that were designed to detect it. There are variations in the movement patterns of fish populations both between and within watersheds. Consequently, a prudent assumption is that if salmonids are present within the system of interest, they will likely move upstream, but the timing and extent of that movement may vary on a stream-by-stream basis and among species. 

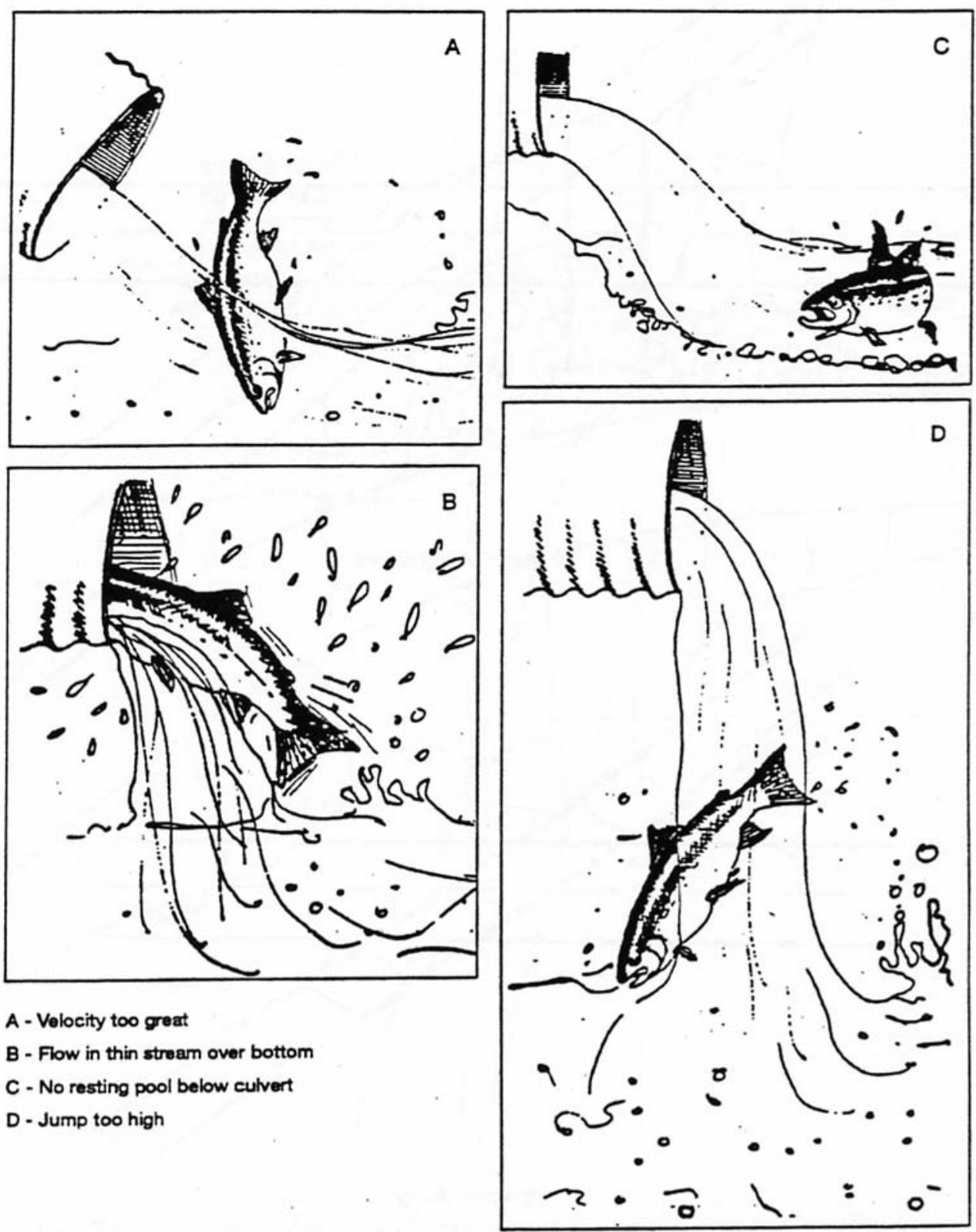

Figure 1. Typical problems at culvert exit that can cause fish passage barriers (Evans and Johnson 1980). 

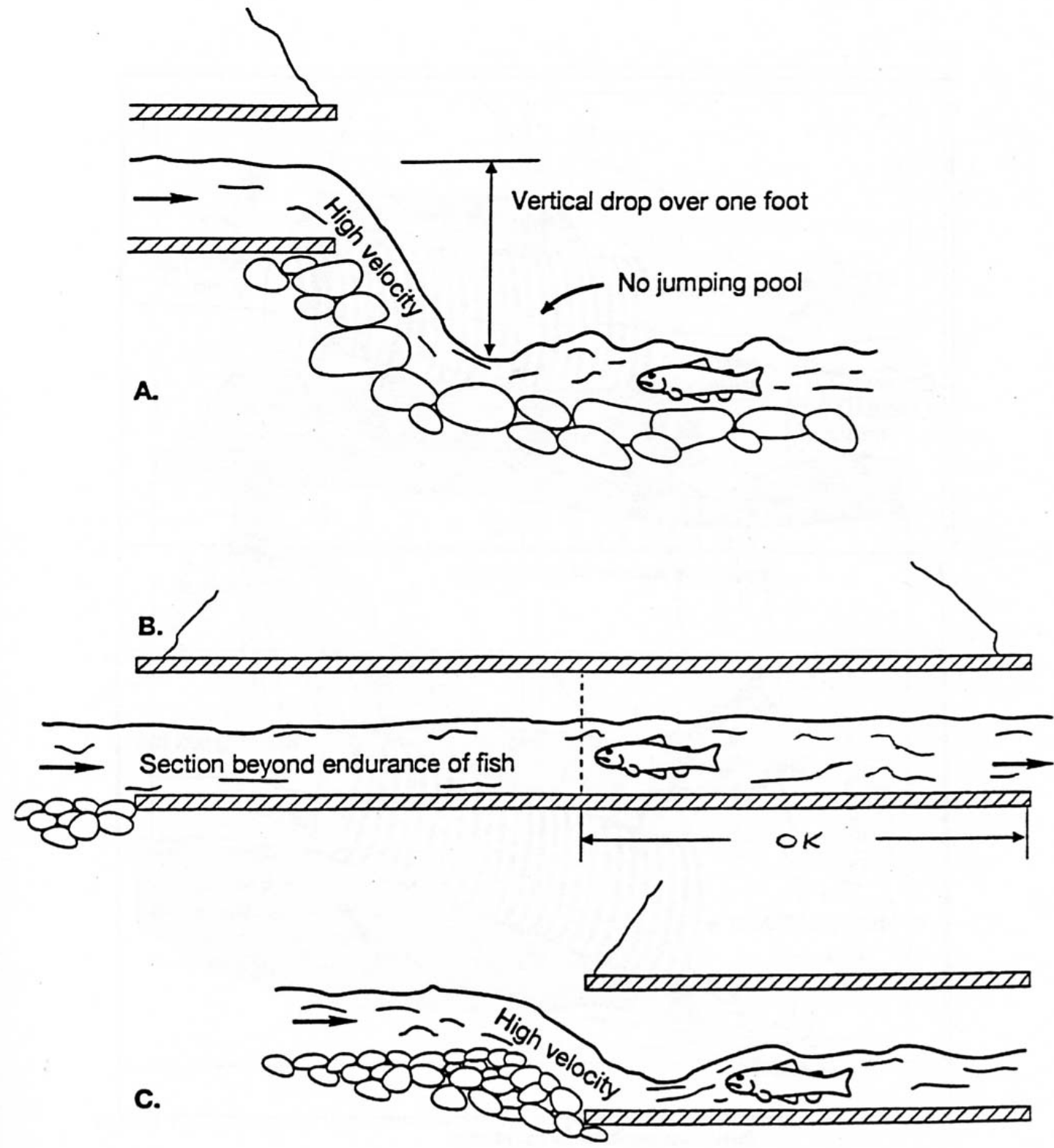

Figure 2. Typical problems with culverts that can cause fish passage barriers (Evans and Johnson 1980). 


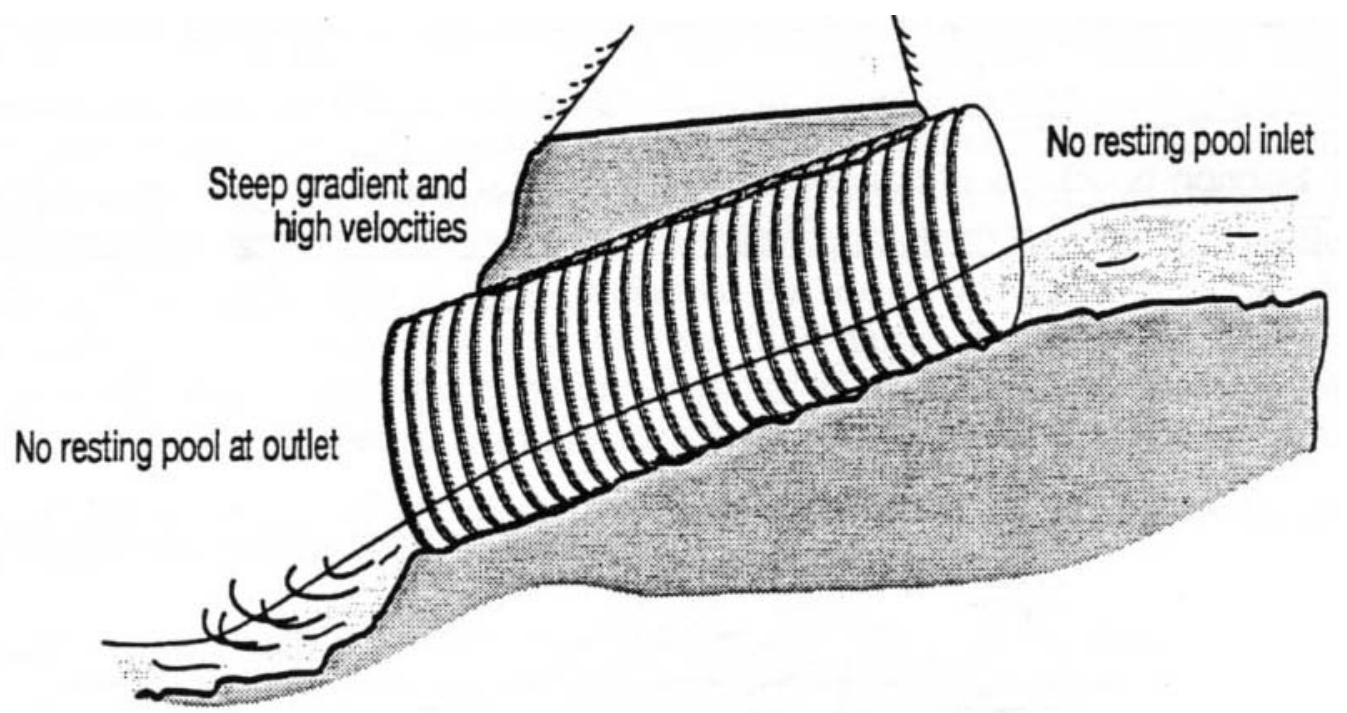

Figure 3. Typical problems with culverts that can cause fish passage barriers (Evans and Johnson, 1980). 


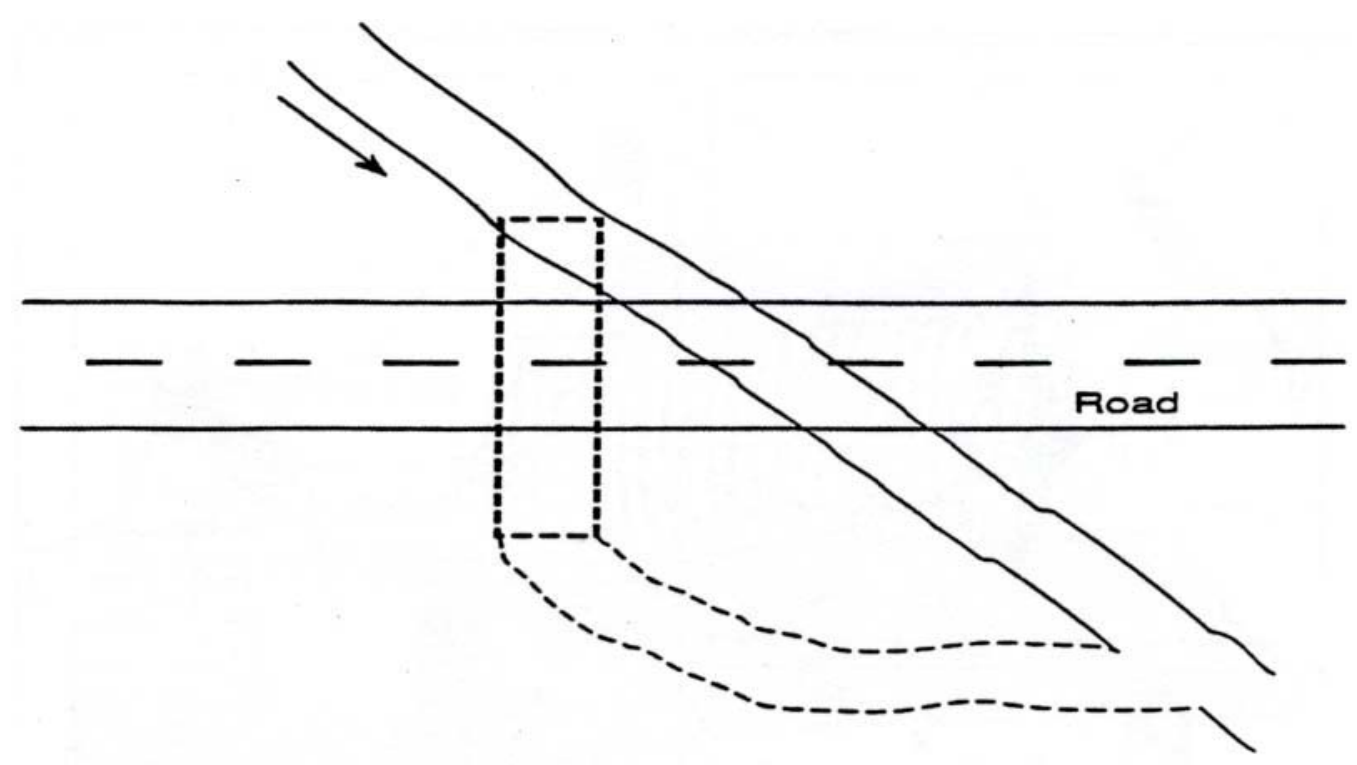

Bad Alignment

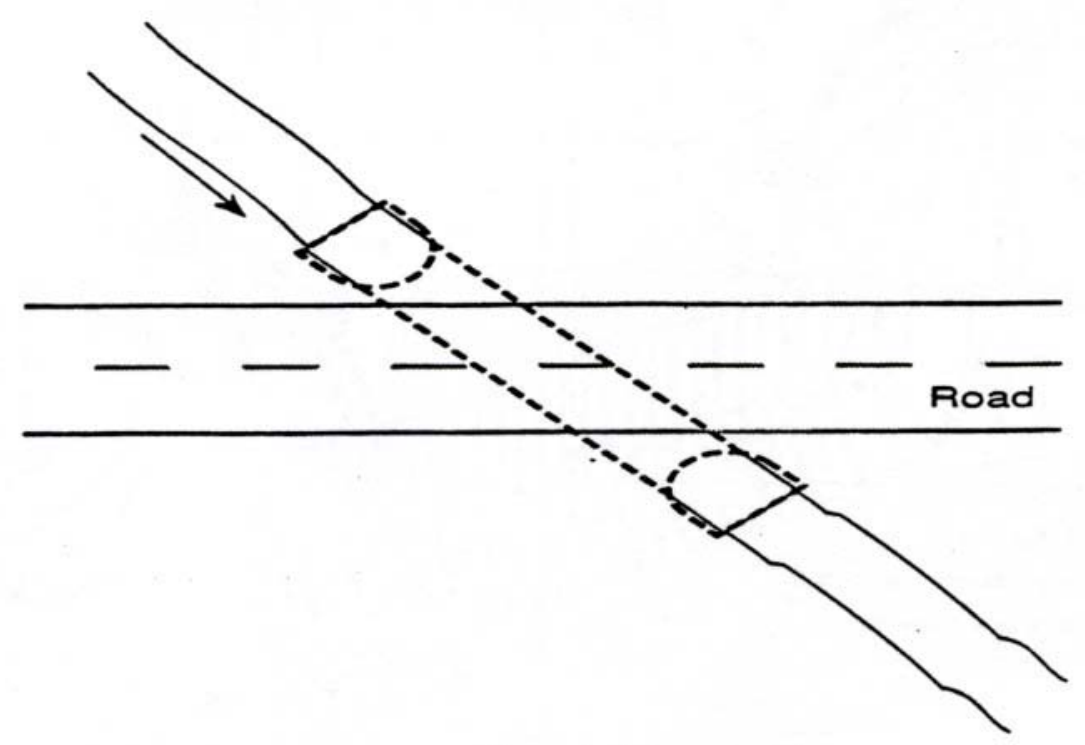

Good Alignment

Figure 4. Typical alignment problems with culverts that can cause fish passage barriers (Evans and Johnson 1980). 
A single survey is inadequate to determine the species and age-class composition within a stream. Kahler and Quinn (1998) found that it is common for fish to use different parts of a stream or watershed at different times of the year. The presence of juveniles in tributaries that support no spawning adults, as well as non-natal tributaries, shows that spawning surveys alone may not indicate juvenile usage. Additionally, the timing of spawning runs may vary within the same watershed. Multiple surveys are necessary to determine the species and age-class composition in a stream, as well as the timing of spawning migrations. Surveys that are targeted to determining the extent and seasonal distribution of juveniles in a watershed are a must.

Ideally, a fish-passage structure or culvert installation should not significantly change the stream conditions that existed prior to the installation. This means that the cross-sectional area of the stream channel should not be restricted by the culvert or bridge structure, the streambed slope should not change, and the streambed roughness characteristics (substrata size distribution) should remain unchanged (Baker and Votapka 1990). In general, culverts must meet both the fish passage criteria and the hydraulic capacity requirements of the drainage. In addition, WDFW recommends that the design of fish passage structures take in consideration the sediment transport capacity of the stream channel and the functional need for large woody debris (LWD) to be able to move through the stream system. This consideration is based on providing natural ecological functions within the stream ecosystem and not just focusing on fish passage alone. Natural processes such as sediment transport, flow regime, and LWD recruitment are critical to instream fish habitat formation and maintenance. It is also widely recognized that when these natural habitat-forming processes are incorporated into fish passage design, operational and maintenance (O\&M) activities on fish passage structures will generally be reduced.

Based on experience and research (Baker and Votapka 1990), the following structures should be considered to provide adequate streamflow capacity and fish passage, in order of preference based on long-term effectiveness (Figures 5, 6, 7, \& 8):

- A bridge with no encroachment into the stream channel and 100-year floodplain

- A bridge that spans the stream channel (bank-full width), but may constrain floodplain or channel migration zone (CMZ) functions

- A culvert sized to provide unrestricted flow at bank-full flow conditions, with a natural streambed bottom: This can be accomplished using a bottomless arched culvert, an embedded culvert design, or some other "stream simulation" approach. Stream simulation refers to a condition in which the substrata and flow within the culvert mimic the natural streambed and flow conditions upstream and downstream of the culvert.

- A "zero-slope" $(<0.5 \%)$ non-embedded culvert, properly sized for streamflow conditions: This approach may require multiple culverts to provide conveyance during all flow conditions.

- A baffled culvert, culvert with grade-control structures (weirs), or a culvert with a fishway or "fish ladder" attached. 


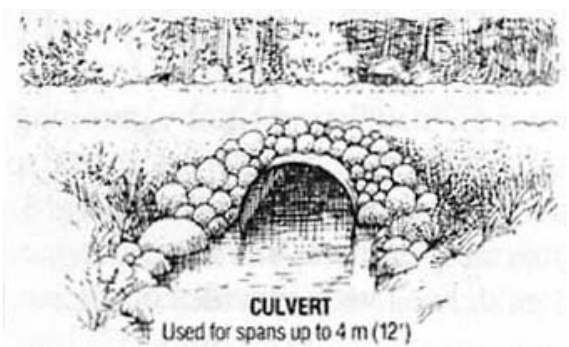

Figure 5. Standard culvert fish-passage option (Evans and Johnson, 1980).

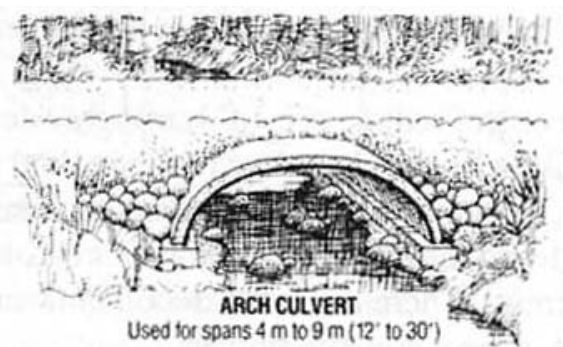

Figure 6. Arched culvert fish-passage option (Evans and Johnson, 1980).

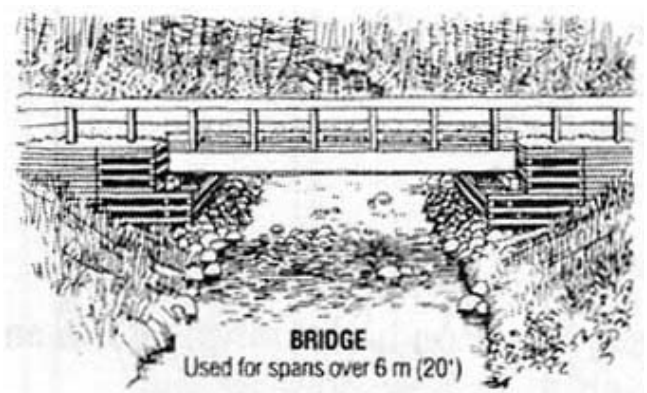

Figure 7. Bridge fish-passage option (Evans and Johnson, 1980). 


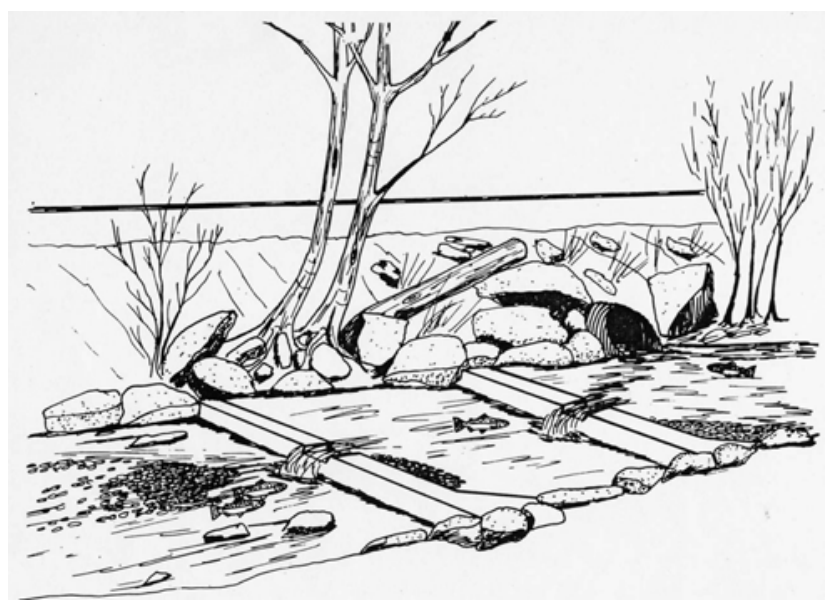

Figure 8. Grade-control weirs (Evans and Johnson, 1980). 


\subsection{METHODS}

The assessment protocols described in the Fish Passage Barrier and Surface Water Diversion Screening, Assessment, and Prioritization Manual (WDFW 2000) were used to evaluate the fish-passage potential of the culverts under the Navy railroad between Silverdale and Shelton for this project. The fish-passage barrier assessment process is described in detail in the manual. An overview of the process is shown in Figure 9.

The initial listing of potential fish-passage barriers along the study reach was provided by PSNS \& IMF, based on an earlier screening-level survey conducted with technicians from the South Puget Sound Salmon Enhancement Group (SPSSEG) as part of the LFA process. This list was checked against the master Navy railroad list of culverts. In addition, the Washington Department of Natural Resources (WADNR) hydrologic map and geographical information system (GIS) databases were used to check for any intersections with the railroad line that might be the site of potential culverts or fish-passage barriers. Information was also solicited from Hood Canal Salmon Enhancement Group (HCSEG) and Native American Tribes (Squaxin, Suquamish, and Skokomish) with jurisdiction in the area. Based on this presurvey investigation, a list of railroad culverts was compiled for which field surveys would be conducted. A number of these culverts had already been identified as barriers or potential barriers during the WRIA14 and 15 LFA process (WCC 2001; 2002) by tribal fisheries departments, WDFW personnel, and salmon restoration groups (e.g., SPSSEG and HCSEG). Field surveys were then conducted to evaluate these known and potential fish-passage barrier culverts on the Navy railroad line. Interns from the Northwest Indian College, who were trained by WDFW culvert-survey technicians and supervised by Pacific Northwest National Laboratory (PNNL) field biologists, conducted the field surveys during the summer of 2003.

For each culvert evaluated, the location was determined using the global positioning system (GPS). A determination was made as to whether the streams should be considered fish-bearing or not. A detailed fish survey using traps or electro-fishing methods was beyond the scope of this project. Instead, standard WDFW criteria were used to determine the fish-bearing status of each stream segment.

To be considered as a fish-bearing stream, at least one of the following criteria had to apply to each stream segment surveyed:

- having a mean bank-full width greater than $0.6 \mathrm{~m}$ and an average stream gradient less than $20 \%$

- identified as fish-bearing in the WDFW Priority Habitats and Species database.

- $\quad$ identified as WA-DNR Type 1, 2, 3, or 4

- listed in the WDFW Catalog of Washington Streams and Salmon Utilization, or "Stream Catalog,” as fish-bearing

- listed as fish-bearing on the Stream-Net web site (http://www.streamnet.org/) or in LFA reports

- having documented salmonid use, as determined by visual observation, electro-fishing, or verification by local biologists.

PNNL scientists conducted an initial survey of all railroad line culverts identified as known or potential fish-passage barriers on 17 April 2003. If a stream was determined to be non-fish bearing, only limited information (culvert diameter, length, and type) was collected on the culvert. For fish-bearing streams, additional surveys were scheduled to collect detailed data on the culvert and instream physical habitat conditions, both upstream and downstream of the culvert. The level of detail collected on the culvert depended on whether barrier status was determined by the WDFW Level-A analysis (Figure 10; Table 2) 


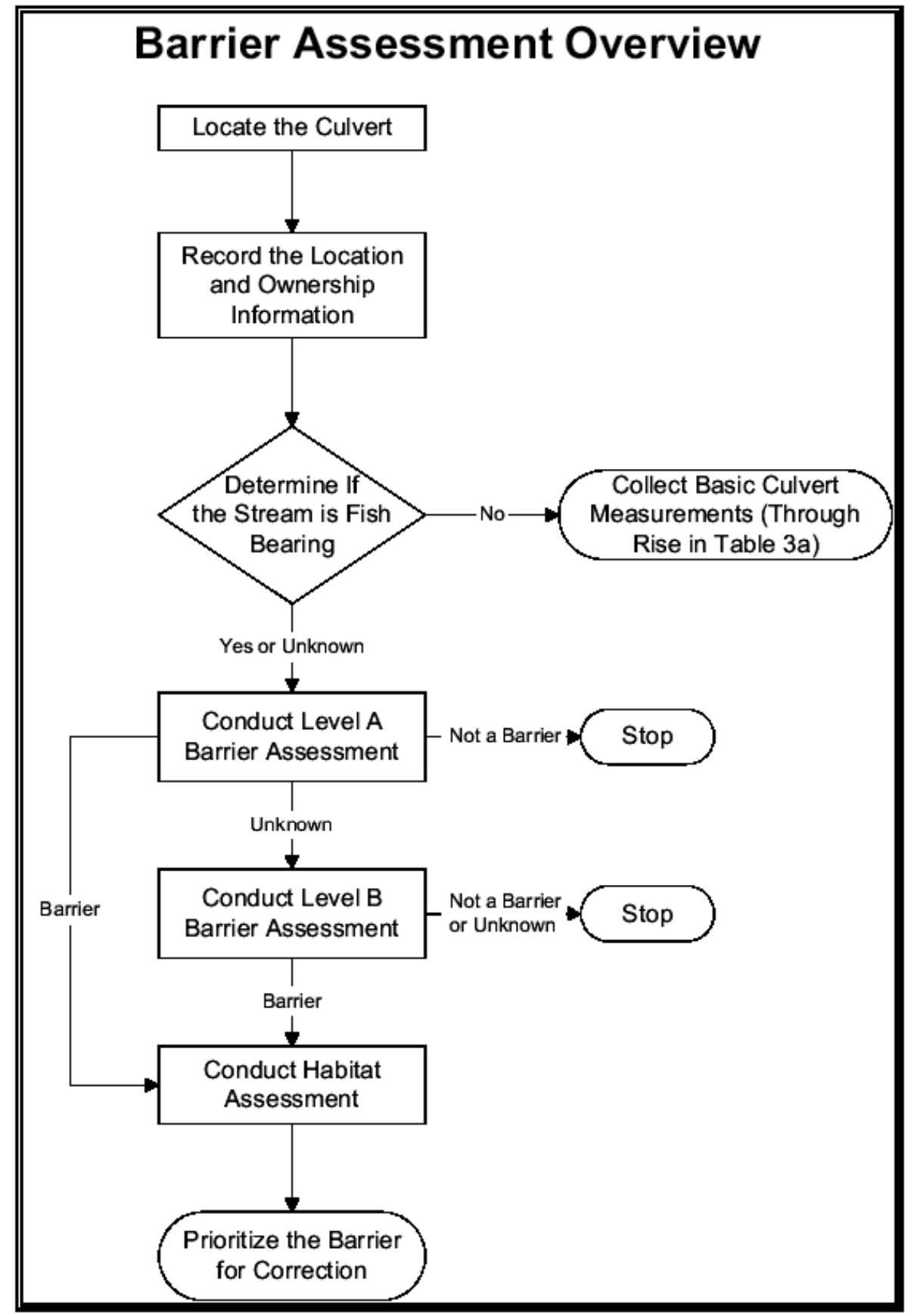

Figure 9. Overview of Fish-Passage Barrier Assessment Process (WDFW 2000). 


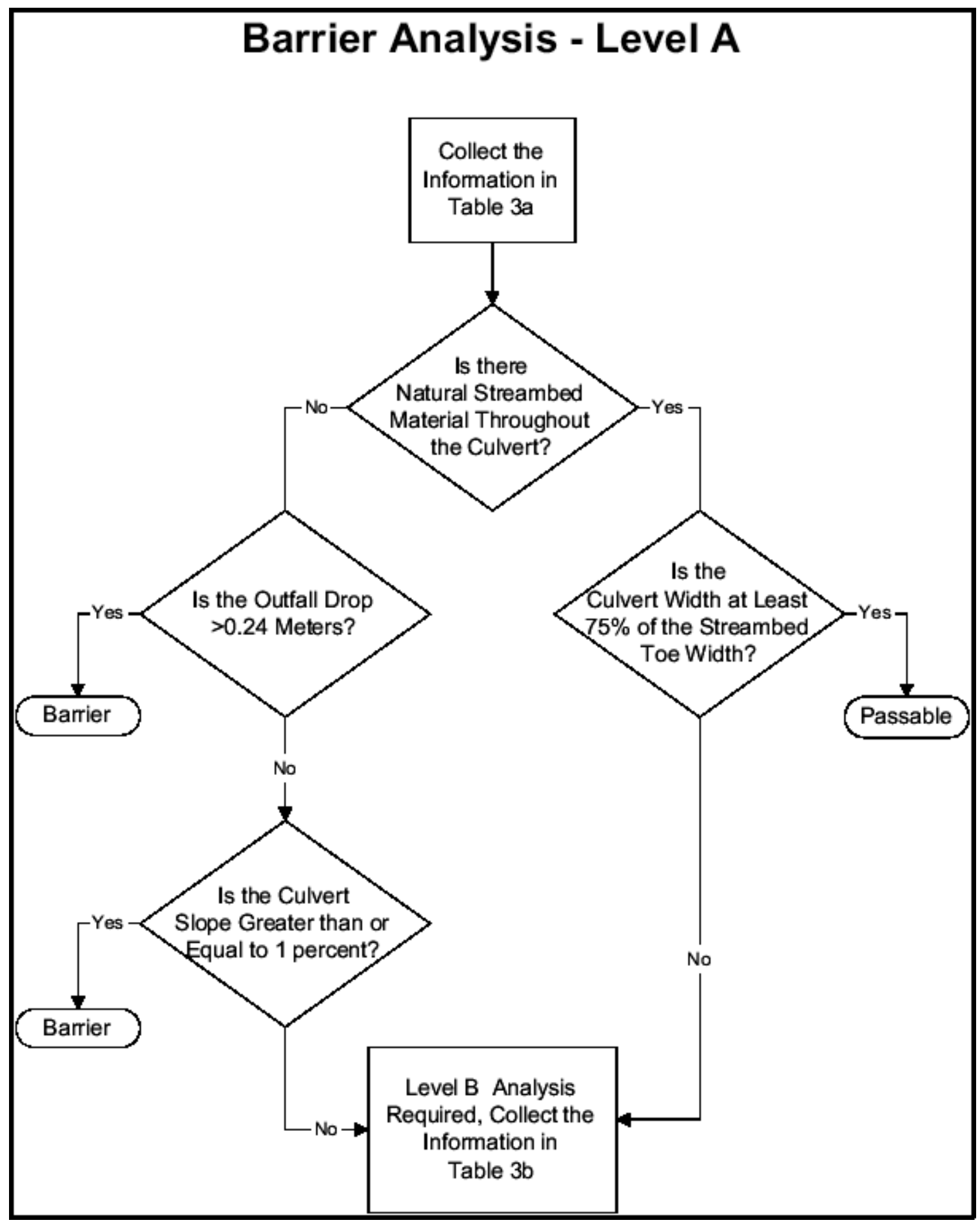

Figure 10. Overview of Level-A Fish-Passage Barrier Assessment Process (WDFW 2000). 
Table 2. Level-A Survey Data (WDFW 2000)

\begin{tabular}{|c|c|}
\hline Attribute & Description \\
\hline Sequencer & $\begin{array}{l}\text { Identifies individual culverts at multiple culvert stream crossings. Format } X . Y \text {, where } X \\
=\text { specific culvert number and } Y=\text { total number of culverts in crossing. For example at a } \\
\text { triple culvert crossing the first pipe would be } 1.3 \text {, the second } 2.3 \text { and the third } 3.3 \text {. Used } \\
\text { in conjunction with Site ID to create a unique record ID. }\end{array}$ \\
\hline Field Review Crew & $\begin{array}{l}\text { Last names of individuals responsible for collecting field data on culverts. Separate } \\
\text { names with /. }\end{array}$ \\
\hline Field Review Date & Date of the field review. MM/DD/YYYY format. \\
\hline Shape & $\begin{array}{l}\text { Specify the shape of the culvert using one of the following codes: } \mathbf{R N D}=\text { round, } \mathbf{B O X}= \\
\text { rectangular, } \mathbf{A R C H}=\text { bottomless arch, } \mathbf{S Q S H}=\text { squash (pipe } \text { arch), ELL }=\text { ellipse, } \\
\text { OTH }=\text { other. }\end{array}$ \\
\hline Material & $\begin{array}{l}\text { Specify the material of which the culvert is constructed using one of the following codes: } \\
\text { PCC = precast concrete, } \mathbf{C P C}=\text { cast in place concrete, } \mathbf{C S T}=\text { corrugated steel, } \mathbf{S S T}= \\
\text { smooth steel, } \mathbf{C A L}=\text { corrugated aluminum }, \mathbf{S P S}=\text { structural plate steel, SPA }=\text { structural } \\
\text { plate aluminum, } \mathbf{P V C}=\text { plastic, TMB }=\text { timber, } \mathbf{M R Y}=\text { masonry, } \mathbf{O T H}=\text { other. }\end{array}$ \\
\hline Span & $\begin{array}{l}\text { The horizontal dimension of the culvert. Expressed in meters to the nearest } 0.01 \text {. Used } \\
\text { in conjunction with Average Streambed Width to calculate Culvert Span to Streambed } \\
\text { Width Ratio. }\end{array}$ \\
\hline Rise & $\begin{array}{l}\text { The vertical dimension of the culvert. Expressed in meters to the nearest } 0.01 \text {. For } \\
\text { round culverts this value will be the same as the span. }\end{array}$ \\
\hline $\begin{array}{l}\text { Water Depth Inside } \\
\text { Culvert }\end{array}$ & $\begin{array}{l}\text { Depth of water inside the culvert, measured at the downstream end away from the } \\
\text { influence of outlet conditions. Expressed in meters to the nearest } 0.01 \text {. }\end{array}$ \\
\hline Outfall Drop & $\begin{array}{l}\text { Distance from the water surface at the downstream end of the culvert to the water surface } \\
\text { of the plunge pool. If the stream is dry, the outfall drop is the difference between the } \\
\text { downstream invert elevation and the elevation of the plunge pool control. Expressed in } \\
\text { meters to the nearest } 0.01 \text {. }\end{array}$ \\
\hline Length & The length of the culvert measured to the nearest 0.1 meters. Include aprons if present. \\
\hline Culvert Slope & $\begin{array}{l}\text { Slope of the culvert, reported in percent (e.g. 4.3). May be a positive or negative } \\
\text { number. May be shot directly with laser or derived from invert elevations and culvert } \\
\text { length. Slope readings taken with a clinometer are not acceptable. }\end{array}$ \\
\hline $\begin{array}{l}\text { Streambed Material } \\
\text { in Culvert }\end{array}$ & $\begin{array}{l}\text { Specifies the presence of streambed material throughout the length of the culvert. } \\
\text { Values are; yes or no. }\end{array}$ \\
\hline $\begin{array}{l}\text { Water Velocity } \\
\text { Inside Culvert }\end{array}$ & $\begin{array}{l}\text { Field estimate of water velocity through the culvert in meters per second. Use flow } \\
\text { meter or } 3 \text { chip method. Informational. Optional. }\end{array}$ \\
\hline Apron & $\begin{array}{l}\text { Indicates presence and location of an apron. Values are: none, upstream, downstream, } \\
\text { both (both ends). }\end{array}$ \\
\hline Tidegate & Indicates presence of a tidegate. Values are: yes or no. \\
\hline Fill Depth & Depth of road fill over culvert. Measured to the nearest meter. \\
\hline Plunge Pool Length & $\begin{array}{l}\text { Distance from the outlet of the culvert to the downstream control. Measured in meters to } \\
\text { the nearest } 0.01 \text {. }\end{array}$ \\
\hline $\begin{array}{l}\text { Plunge Pool } \\
\text { Maximum Depth }\end{array}$ & $\begin{array}{l}\text { Maximum depth of plunge pool. Expressed in meters to the nearest } 0.01 \text {. } \\
\text { Informational. }\end{array}$ \\
\hline $\begin{array}{l}\text { Plunge Pool OHW } \\
\text { Width }\end{array}$ & $\begin{array}{l}\text { Width of the plunge pool at its widest point measured at Ordinary High Water. } \\
\text { Expressed in meters to the nearest 0.1. Informational. }\end{array}$ \\
\hline
\end{tabular}




\begin{tabular}{|c|c|}
\hline Attribute & Description \\
\hline $\begin{array}{l}\text { Average Streambed } \\
\text { Width }\end{array}$ & $\begin{array}{l}\text { The average width of the streambed (toe width). Measured at the second riffle } \\
\text { downstream of the culvert. Used in conjunction with culvert span to calculate Culvert } \\
\text { Span to Streambed Width Ratio. }\end{array}$ \\
\hline $\begin{array}{l}\text { Culvert Span to } \\
\text { Streambed Width } \\
\text { Ratio }\end{array}$ & $\begin{array}{l}\text { The ratio of culvert width (span or diameter) to streambed (toe) width. Derived by } \\
\text { dividing culvert span by average streambed width. Expressed as a decimal fraction. }\end{array}$ \\
\hline $\begin{array}{l}\text { Maintenance } \\
\text { Required }\end{array}$ & $\begin{array}{l}\text { Indicates if culvert is in need of maintenance, valid entries include: } \mathbf{n o}=\text { no maintenance } \\
\text { needed, yes } / \mathbf{f p}=\text { maintenance needed to improve fish passage (culvert not a barrier } \\
\text { otherwise), yes } / \mathbf{o m}=\text { maintenance needed, fish passage not an issue. }\end{array}$ \\
\hline Recheck & $\begin{array}{l}\text { Need/reason to re-visit the site. Field values are not rigid but please use the following } \\
\text { for consistency. Maximum number of characters is } 10 \text {. Use the comment field if } \\
\text { necessary. Once the recheck has been done, the field value needs to be toggled to no } \\
\text { and comments cleared to avoid future confusion. no }=\text { no need, } \mathbf{G P S}=\text { gps position, } \\
\text { photo }=\text { photo, pass } \mathbf{H F}=\text { evaluate passability at high flow, pass } \mathbf{L F}=\text { evaluate } \\
\text { passability at low flow, } \mathbf{L B}=\text { Level B data required. }\end{array}$ \\
\hline Barrier & $\begin{array}{l}\text { Results of fish passage evaluation. Values are; yes }=\text { culvert is a barrier, no }=\text { culvert is } \\
\text { not a barrier, unknown = culvert beyond Level B analysis. If the stream is non-fish } \\
\text { bearing the field is left blank. }\end{array}$ \\
\hline Passability & $\begin{array}{l}\text { Percent passability based on field crews professional judgement. Values are } 0,33,67 \text {, } \\
100 \text {. This value is used in the PI model to derive B (proportion of fish passage } \\
\text { improvement). Make sure values in the Passability and Barrier fields are consistent. If } \\
\text { the stream is non-fish bearing the field is left blank. For non WDFW crews the } \\
\text { passability is assumed to be } 0.33 \text { unless the individuals making the assessment have an } \\
\text { advanced level of expertise. }\end{array}$ \\
\hline Problem & $\begin{array}{l}\text { Factor that determined barrier status. Applies only to barrier culverts. Entries include } \\
\text { outfall drop, slope, velocity, and depth. Enter outfall drop if the measured outfall drop } \\
\text { is }>0.24 \text { meters or enter slope if the slope is }>1 \% \text { (Level A Analysis). The results of the } \\
\text { hydraulic analysis (Level B) will indicate either water depth or velocity. Enter all that } \\
\text { apply, separate each entry with a /. }\end{array}$ \\
\hline Repair Status & $\begin{array}{l}\text { Indicates the need for barrier repair. If the culvert is not a barrier enter OK. If there is } \\
\text { insufficient habitat gain to warrant repair (see Threshold Determination, Section 3.3) the } \\
\text { entry would be NG (no gain). If sufficient habitat is present enter } \mathbf{R R} \text { (repair required). } \\
\text { If the barrier has been fixed enter FX (fixed). If the fix involves conversion to a fishway } \\
\text { enter FX/FW. If a threshold determination has not been made enter } \mathbf{U D} \text { (undetermined). } \\
\text { If the stream is non-fish bearing the field is left blank. }\end{array}$ \\
\hline Comments & $\begin{array}{l}\text { Concise description of culvert problem and explanation of any attribute where OTHER } \\
\text { was selected. }\end{array}$ \\
\hline
\end{tabular}

or whether a more detailed Level-B analysis was required (Figure 11; Table 3). If the culvert was determined to be a barrier based on a Level-A survey, no further data were collected. If the barrier status was still undetermined after the Level-A survey, then a Level-B analysis was conducted. The WDFW Level-A surveys were conducted on all known or potential barrier railroad culverts along the study reach on May 19, 21, 22, and June 9 of 2003. A total of 21 culverts were surveyed. Culverts requiring Level-B analysis and habitat assessment were scheduled for detailed surveys during the summer of 2003. All culvert surveys were completed by the end of August 2003. 


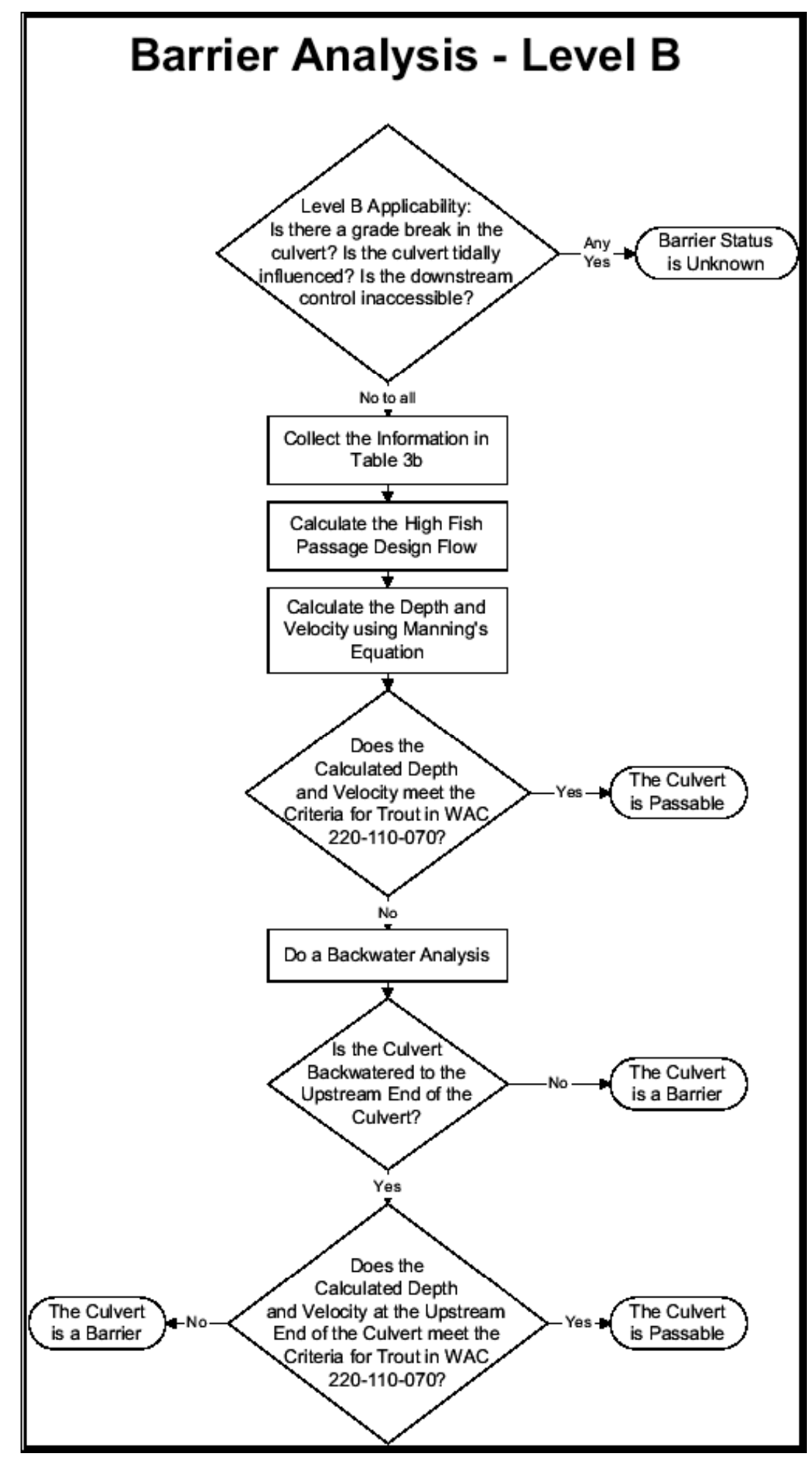

Figure 11. Overview of Level B Fish-Passage Barrier Assessment Process (WDFW, 2000). 
Table 3. Level-B Survey Data (WDFW, 2000)

\begin{tabular}{|c|c|}
\hline Attribute & Description \\
\hline Reference Point Datum & $\begin{array}{l}\text { Specify the datum of the reference point (benchmark). Expressed in meters to the } \\
\text { nearest } 0.01 \text {. May be an established datum or a local assumed datum. }\end{array}$ \\
\hline Reference Point Location & Describe the location of the survey reference point (benchmark). \\
\hline $\begin{array}{l}\text { Culvert Elevation - } \\
\text { Upstream }\end{array}$ & $\begin{array}{l}\text { Elevation of the culvert bottom (invert) at the upstream end. Expressed in meters to } \\
\text { the nearest } 0.01\end{array}$ \\
\hline $\begin{array}{l}\text { Culvert Streambed } \\
\text { Elevation - Upstream }\end{array}$ & $\begin{array}{l}\text { The surface elevation of anv streambed material inside the culvert at the upstream } \\
\text { end. Expressed in meters to the nearest } 0.01 \text {. Used to determine streambed slope } \\
\text { through the culvert and actual flow area for the hydraulic model. If streambed } \\
\text { material is not present throughout the length of the culvert leave blank. }\end{array}$ \\
\hline Corrugation & $\begin{array}{l}\text { For corrugated pipes record the dimensions of the corrugations. These are used in } \\
\text { the hydraulic model to determine roughness coefficient. Dimensions are depth by } \\
\text { width (peak to peak), measured in inches. The following three corrugations will } \\
\text { cover } 95 \% \text { of corrugated pipes: } 0.5 \times 2.66,1 \times 3 \text {, and } 2 \times 6 \text {. If different specify } \\
\text { using the same format. For non-corrugated pipes enter smooth. For culverts with } \\
\text { concrete or asphalt covering the corrugations on the invert, enter paved. }\end{array}$ \\
\hline $\begin{array}{l}\text { Culvert Elevation - } \\
\text { Downstream }\end{array}$ & $\begin{array}{l}\text { Elevation of the culvert bottom (invert) at the downstream end. Expressed in } \\
\text { meters to the nearest } 0.01\end{array}$ \\
\hline $\begin{array}{l}\text { Culvert Streambed } \\
\text { Elevation - Downstream }\end{array}$ & $\begin{array}{l}\text { The surface elevation of } \underline{a n y} \text { streambed material inside the culvert at the downstream } \\
\text { end. Expressed in meters to the nearest } 0.01 \text {. Used to determine streambed slope } \\
\text { through the culvert and actual flow area for the hydraulic model. If streambed } \\
\text { material is not present throughout the length of the culvert leave blank. }\end{array}$ \\
\hline $\begin{array}{l}\text { Downstream Control } \\
\text { Cross Section } \\
\text { ST0..ST6 } \\
\text { EL0..EL6 }\end{array}$ & $\begin{array}{l}\text { The downstream control is typically the head of the first riffle below the culvert (5- } \\
10 \text { meters downstream). The cross section is derived from at least } 7 \text { points across } \\
\text { the channel. Data is recorded as station (ST0..6) and elevation (EL0..6). Start at the } \\
\text { top of the left bank (ST0 \& EL0), looking downstream, and work to the right. } \\
\text { Measure elevations at the top of each bank, each toe, the thalweg, and other grade } \\
\text { breaks. Value for ST0 will always be } 0 \text {, values for ST1..6 will be the distance in } \\
\text { meters measured to the nearest } 0.01 \text { from ST0. Elevations are measured in meters to } \\
\text { the nearest } 0.01 \text {. Used in the hydraulic model. Each station and elevation is a } \\
\text { separate field in the database. }\end{array}$ \\
\hline $\begin{array}{l}\text { DS Control Water } \\
\text { Surface Elevation }\end{array}$ & $\begin{array}{l}\text { Elevation of the water surface at the downstream control. Measured in meters to the } \\
\text { nearest } 0.01 \text {. Derived by adding water depth to the bed elevations at the control. } \\
\text { Used in conjunction with the downstream culvert elevation and WDIC to determine } \\
\text { hydraulic drop. }\end{array}$ \\
\hline $\begin{array}{l}\text { DS Control OHW } \\
\text { Elevation }\end{array}$ & $\begin{array}{l}\text { Elevation of Ordinary High Water at the downstream control. Measured in meters } \\
\text { to the nearest } 0.01 \text {. }\end{array}$ \\
\hline $\begin{array}{l}\text { Water Surface Elevation } \\
15 \text { meters Downstream of } \\
\text { DS Control }\end{array}$ & $\begin{array}{l}\text { Water surface elevation at the channel centerline, } 15 \text { meters downstream of the } \\
\text { downstream control. Measured in meters to the nearest } 0.01 \text {. Derived by adding } \\
\text { Downstream Bed Elevation and water depth. Used in hydraulic model. Also used in } \\
\text { conjunction with upstream water surface elevation to estimate stream gradient } \\
\text { through the reach. }\end{array}$ \\
\hline $\begin{array}{l}\text { Channel Dominant } \\
\text { Substrate }\end{array}$ & $\begin{array}{l}\text { Best description of the dominant substrate in the channel between the culvert and } \\
\text { the point } 15 \text { meters downstream of the downstream control. Select one of the } \\
\text { following: riprap, boulder, cobble, gravel, sand, mud, bedrock Needed for the } \\
\text { hydraulic model. }\end{array}$ \\
\hline
\end{tabular}


The objectives of these surveys were to determine whether the barrier culverts are accessible to salmonids (i.e., no downstream natural migration barriers) or whether there were other blocking culverts affecting the same stream, and to quantify the potential habitat gain if the culvert barriers were corrected. Once the potential habitat gain was quantified, it was possible to compare and prioritize culvert projects based on a standardized score. The WDFW PI score was designed for this purpose (WDFW 2000). The PI score takes into account the number of species utilizing the stream, the quantity of habitat gain, the quality of the potential habitat, the mobility of the species utilizing the stream, the health of the stocks that would benefit from the increased access to upstream habitat, and the projected cost of the project

(WDFW 2000).

\subsection{FINDINGS}

Tables 4 and 5 contain a summary of the data developed during this project for each Navy railroad culvert of interest. Only a few potential fish-passage barriers were eliminated from consideration based on their location on non-fish bearing streams or ephemeral channels. Several of the culverts were also found to be in compliance with fish-passage criteria and were not listed as barriers. However, of the 21 culverts surveyed, three (3) were found to be complete fish-passage barriers and another seven (7) were found to be partial (mostly juvenile blockages under specific flow conditions) fish-passage barriers.

Of the identified barriers, two (2) had a PI score above 10 and six (6) others had a PI score between 7 and 10 (see Table 5). The remainder of this section of the report contains a detailed description of each railroad culvert surveyed. For this report, the culverts are identified primarily by their railroad milepost (MP). Table 4 delineates stream name, WRIA number, and GPS location. PI score sheets are included in Appendix A.

Table 4. Summary of Navy Railroad Culvert General Information

\begin{tabular}{|c|c|c|c|c|c|c|c|c|}
\hline \begin{tabular}{|l|} 
RR \\
MP
\end{tabular} & \begin{tabular}{|l} 
Stream Watershed \\
Description
\end{tabular} & \begin{tabular}{|l} 
GPS \\
Way-Pt
\end{tabular} & GPS Coordinates (Deg,min,sec) & WRIA\# & County & Tribe & $\begin{array}{c}\text { Perennial } \\
\text { Stream }\end{array}$ & \begin{tabular}{|c|}
$\begin{array}{c}\text { Fish-Bearing } \\
\text { Stream }\end{array}$ \\
\end{tabular} \\
\hline 2.19 & Un-Named Creek & 146 & $47^{\circ} 13^{\prime} 45.5^{\prime \prime} 123^{\circ} 04^{\prime} 21.8^{\prime \prime}$ & 14.0047 & Mason & Squaxin & $\mathrm{Y}$ & $P$ \\
\hline 3.79 & Johns Creek & 162 & $47^{\circ} 15^{\prime} 06.0^{\prime \prime} 123^{\circ} 04^{\prime} 13^{\prime \prime}$ & 14.0049 & Mason & Squaxin & Y & Y \\
\hline 6.60 & Cranberry Creek & 147 & $47^{\circ} 16^{\prime} 45.7^{\prime \prime} 123^{\circ} 02^{\prime} 41.8^{\prime \prime}$ & 14.0051 & Mason & Squaxin & Y & Y \\
\hline 7.52 & Cranberry Creek Tributary & 165 & $47^{\circ} 16^{\prime} 36^{\prime \prime} 123^{\circ} 01^{\prime} 34^{\prime \prime}$ & 14.0052 & Mason & Squaxin & $\mathrm{N}$ & $P$ \\
\hline 8.90 & Deer Creek Tributary & 149 & $47^{\circ} 17^{\prime} 16.4^{\prime \prime} 123^{\circ} 00^{\prime} 16.8^{\prime \prime}$ & $\mathrm{N} / \mathrm{A}$ & Mason & Squaxin & Y & Y \\
\hline 9.28 & Deer Creek Tributary & 166 & $47^{\circ} 17^{\prime} 23^{\prime \prime} 123^{\circ} 59^{\prime} 46^{\prime \prime}$ & $\mathrm{N} / \mathrm{A}$ & Mason & Squaxin & $\mathrm{N}$ & $P$ \\
\hline 10.50 & Deer Creek Tributary & 167 & $47^{\circ} 17^{\prime} 59^{\prime \prime} 122^{\circ} 58^{\prime} 30^{\prime \prime}$ & $\mathrm{N} / \mathrm{A}$ & Mason & Squaxin & Y & Y \\
\hline 12.01 & Deer Creek Tributary & 160 & $47^{\circ} 18^{\prime} 48.8^{\prime \prime} 122^{\circ} 57^{\prime} 06.2^{\prime \prime}$ & 14.0060 & Mason & Squaxin & $\mathrm{N}$ & Y \\
\hline 12.73 & Deer Creek Tributary & 150 & $47^{\circ} 19^{\prime} 06.3^{\prime \prime} 122^{\circ} 56^{\prime} 20.8^{\prime \prime}$ & 14.0061 & Mason & Squaxin & Y & Y \\
\hline 13.10 & Deer Creek Tributary & 151 & $47^{\circ} 19^{\prime} 17.2^{\prime \prime} 122^{\circ} 55^{\prime} 56.1^{\prime \prime}$ & 14.0065 & Mason & Squaxin & Y & Y \\
\hline 14.89 & Deer Creek Tributary & 152 & $47^{\circ} 20^{\prime} 10.4^{\prime \prime} 122^{\circ} 54^{\prime} 10.7^{\prime \prime}$ & 14.0066 & Mason & Squaxin & Y & Y \\
\hline 17.84 & Sherwood Creek Tributary & 163 & $47^{\circ} 22^{\prime} 14^{\prime \prime} 122^{\circ} 51^{\prime} 50^{\prime \prime}$ & $\mathrm{N} / \mathrm{A}$ & Mason & Squaxin & $\mathrm{N}$ & $\mathrm{N}$ \\
\hline 17.96 & Sherwood Creek Tributary & 164 & $47^{\circ} 22^{\prime} 14^{\prime \prime} 122^{\circ} 51^{\prime} 49^{\prime \prime}$ & $\mathrm{N} / \mathrm{A}$ & Mason & Squaxin & $\mathrm{N}$ & $\mathrm{N}$ \\
\hline 21.67 & Lake Devereaux Creek & 159 & $47^{\circ} 25^{\prime} 01.8^{\prime \prime} 122^{\circ} 50^{\prime} 51.4^{\prime \prime}$ & 14.0125 & Mason & Skokomish & $\mathrm{N}$ & Y \\
\hline 28.24 & Union River - Airport Tributary & 153 & $47^{\circ} 29^{\prime} 41.4^{\prime \prime} 122^{\circ} 46^{\prime} 58.1^{\prime \prime}$ & 15.0512 & Kitsap & Skokomish & Y & Y \\
\hline 28.48 & Union River Tributary & 154 & $47^{\circ} 29^{\prime} 49.1^{\prime \prime} 122^{\circ} 46^{\prime} 46.6^{\prime \prime}$ & 15.0514 & Kitsap & Skokomish & $\mathrm{N}$ & Y \\
\hline 30.87 & Gorst Creek Tributary & 155 & $47^{\circ} 31^{\prime} 26.8^{\prime \prime} 122^{\circ} 45^{\prime} 21.0^{\prime \prime}$ & $\mathrm{N} / \mathrm{A}$ & Kitsap & Suquamish & $\mathrm{N}$ & $\mathrm{P}$ \\
\hline 31.55 & Gorst Creek Tributary & 161 & $47^{\circ} 31^{\prime} 35^{\prime \prime} 122^{\circ} 44^{\prime} 32.0^{\prime \prime}$ & 15.0223 & Kitsap & Suquamish & $Y$ & Y \\
\hline 32.09 & Gorst Creek Tributary & 156 & $47^{\circ} 31^{\prime} 53.1^{\prime \prime} 122^{\circ} 44^{\prime} 01.6^{\prime \prime}$ & $\mathrm{N} / \mathrm{A}$ & Kitsap & Suquamish & $\mathrm{N}$ & $P$ \\
\hline 0.71 & Heins Creek (Gorst Trib) & 157 & $47^{\circ} 31^{\prime} 57.4^{\prime \prime} 122^{\circ} 43^{\prime} 10.6^{\prime \prime}$ & 15.0221 & Kitsap & Suquamish & $Y$ & Y \\
\hline 1.04 & Jarstad Creek (Gorst Trib) & 158 & $47^{\circ} 31^{\prime} 55.5^{\prime \prime} 122^{\circ} 42^{\prime} 48.5^{\prime \prime}$ & 15.0218 & Kitsap & Suquamish & Y & Y \\
\hline
\end{tabular}


Table 5. Summary of Navy Railroad Culvert Data

\begin{tabular}{|c|c|c|c|c|c|c|c|c|c|c|c|}
\hline \begin{tabular}{|l|}
$\mathbf{R R}$ \\
MP
\end{tabular} & \begin{tabular}{|l|} 
Stream Watershed \\
Description
\end{tabular} & $\begin{array}{c}\text { Fish Passage } \\
\text { Status }\end{array}$ & \begin{tabular}{|c|} 
LFA-Listed \\
Barrier
\end{tabular} & \begin{tabular}{|c|}
$\begin{array}{c}\text { Survey } \\
\text { Level }\end{array}$ \\
\end{tabular} & \begin{tabular}{|c|} 
Priority \\
Index (PI)
\end{tabular} & \begin{tabular}{|c|} 
Culvert \\
Diameter $(\mathrm{ft})$
\end{tabular} & \begin{tabular}{|c|} 
Culvert \\
Length $(\mathrm{ft})$
\end{tabular} & \begin{tabular}{|c|}
$\begin{array}{c}\text { Culvert } \\
\text { Type }\end{array}$ \\
\end{tabular} & \begin{tabular}{|c|} 
RR Fill \\
Depth ( ft)
\end{tabular} & $\begin{array}{c}\text { RR Trash } \\
\text { Rack }\end{array}$ & $\begin{array}{c}\text { Beaver } \\
\text { Dam/ Pond }\end{array}$ \\
\hline 2.19 & Un-Named Creek & Barrier & $\mathrm{N}$ & $A$ & 6.43 & 6 & 209 & $\mathrm{RCP}$ & 44 & $\mathrm{Y}$ & $\mathrm{N}$ \\
\hline 3.79 & Johns Creek & Passable & $\mathrm{N}$ & N/A & N/A & $8 \times 5$ & 300 & BOX & 36 & $\mathrm{~N}$ & $\mathrm{~N}$ \\
\hline 6.60 & Cranberry Creek & Passable & $\mathrm{N}$ & N/A & N/A & $8 \times 6$ & 144 & $\mathrm{BOX}$ & 24 & $\mathrm{~N}$ & $\mathrm{~N}$ \\
\hline 7.52 & Cranberry Creek Tributary & Passable & $\mathrm{N}$ & A & 6.73 & 3 & 125 & RCP & 33 & $\mathrm{~N}$ & $\mathrm{~N}$ \\
\hline 8.90 & Deer Creek Tributary & Passable & $\mathrm{N}$ & $A$ & 7.32 & 6 & 323 & RCP & 81 & Y & $\mathrm{N}$ \\
\hline 9.28 & Deer Creek Tributary & Passable & $\mathrm{N}$ & $A$ & 7.12 & 4 & 300 & RCP & 40 & Y & $\mathrm{N}$ \\
\hline 10.50 & Deer Creek Tributary & Passable & $\mathrm{N}$ & A & 6.55 & $3(2)$ & 100 & RCP & 22 & $\mathrm{~N}$ & Y \\
\hline 12.01 & Deer Creek Tributary & Passable & $\mathrm{N}$ & $A$ & 7.45 & 5 & 258 & RCP & 33 & $\mathrm{~N}$ & Y \\
\hline 12.73 & Deer Creek Tributary & Barrier & Y & $A$ & 8.59 & 4 & 113 & $\mathrm{RCP}$ & 17 & $\mathrm{~N}$ & $\mathrm{~N}$ \\
\hline 13.10 & Deer Creek Tributary & Passable & $\mathrm{N}$ & $A$ & 8.16 & 6 & 134 & $\mathrm{RCP}$ & 24 & Y & $\mathrm{N}$ \\
\hline 14.89 & Deer Creek Tributary & Passable & $\mathrm{N}$ & $A$ & N/A & 4 & 100 & $\mathrm{RCP}$ & 20 & $\mathrm{~N}$ & Y \\
\hline 17.84 & Sherwood Creek Tributary & N/A & N/A & N/A & $\mathrm{N} / \mathrm{A}$ & 4 & 200 & RCP & 40 & Y & $\mathrm{N}$ \\
\hline 17.96 & Sherwood Creek Tributary & $\mathrm{N} / \mathrm{A}$ & N/A & N/A & N/A & 5 & 205 & $\mathrm{RCP}$ & 40 & Y & $\mathrm{N}$ \\
\hline 21.67 & Lake Devereaux Creek & Barrier & Y & B & 7.34 & 3 & 132 & $\mathrm{RCP}$ & 39 & $\mathrm{~N}$ & $\mathrm{~N}$ \\
\hline 28.24 & Union River - Airport Tributary & Barrier & Y & $A$ & 15.32 & 4 & 278 & RCP & 110 & $\mathrm{~N}$ & $\mathrm{~N}$ \\
\hline 28.48 & Union River Tributary & Passable & $\mathrm{N}$ & $A$ & N/A & 4 & 57 & $\mathrm{RCP}$ & 4 & $\mathrm{~N}$ & $\mathrm{~N}$ \\
\hline 30.87 & Gorst Creek Tributary & Passable & $\mathrm{N}$ & $A$ & N/A & 3 & 133 & $\mathrm{RCP}$ & 22 & $\mathrm{~N}$ & $\mathrm{~N}$ \\
\hline 31.55 & Gorst Creek Tributary & Passable & $\mathrm{N}$ & $A$ & N/A & $8 \times 5$ & 180 & BOX & 40 & $\mathrm{~N}$ & $\mathrm{~N}$ \\
\hline 32.09 & Gorst Creek Tributary & Barrier & Y & $\mathrm{B}$ & 2.17 & 2.5 & 213 & $\mathrm{RCP}$ & 20 & $\mathrm{~N}$ & $\mathrm{~N}$ \\
\hline 0.71 & Heins Creek (Gorst Trib) & Barrier & Y & $A$ & 9.79 & $8 \times 5$ & 159 & $\mathrm{BOX}$ & 55 & N & $\mathrm{N}$ \\
\hline 1.04 & Jarstad Creek (Gorst Trib) & Barrier & $\mathrm{Y}$ & A & 10.17 & 2.5 & 267 & $\mathrm{RCP}$ & 29 & $\mathrm{~N}$ & $\mathrm{~N}$ \\
\hline
\end{tabular}

\subsection{Individual Culvert Assessments}

The following section describes conditions at specific MPs, including location, type of culvert, water flow conditions, potential barriers, and observations of fish. Locations of individual stations are identified on Maps 1 through 3 (Figures 12 , 13, \& 14). 
PSNS CULVERT SURVEY 2003

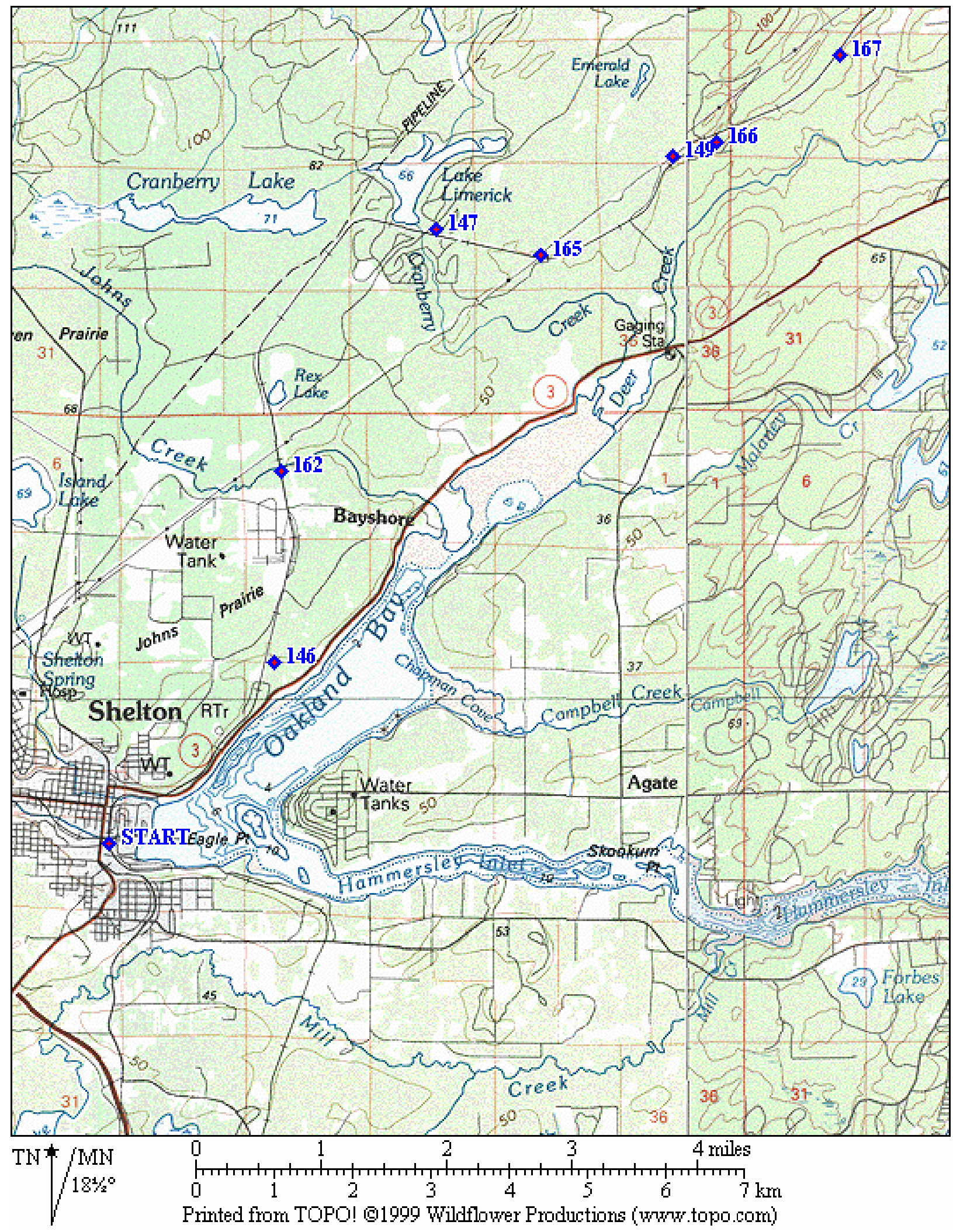

Figure 12. Map 1-Navy railroad line culvert locations.

Railroad Culvert Report

Puget Sound Naval Shipyard and Intermediate Maintenance Facility 
PSNS CULVERT SURVEY 2003

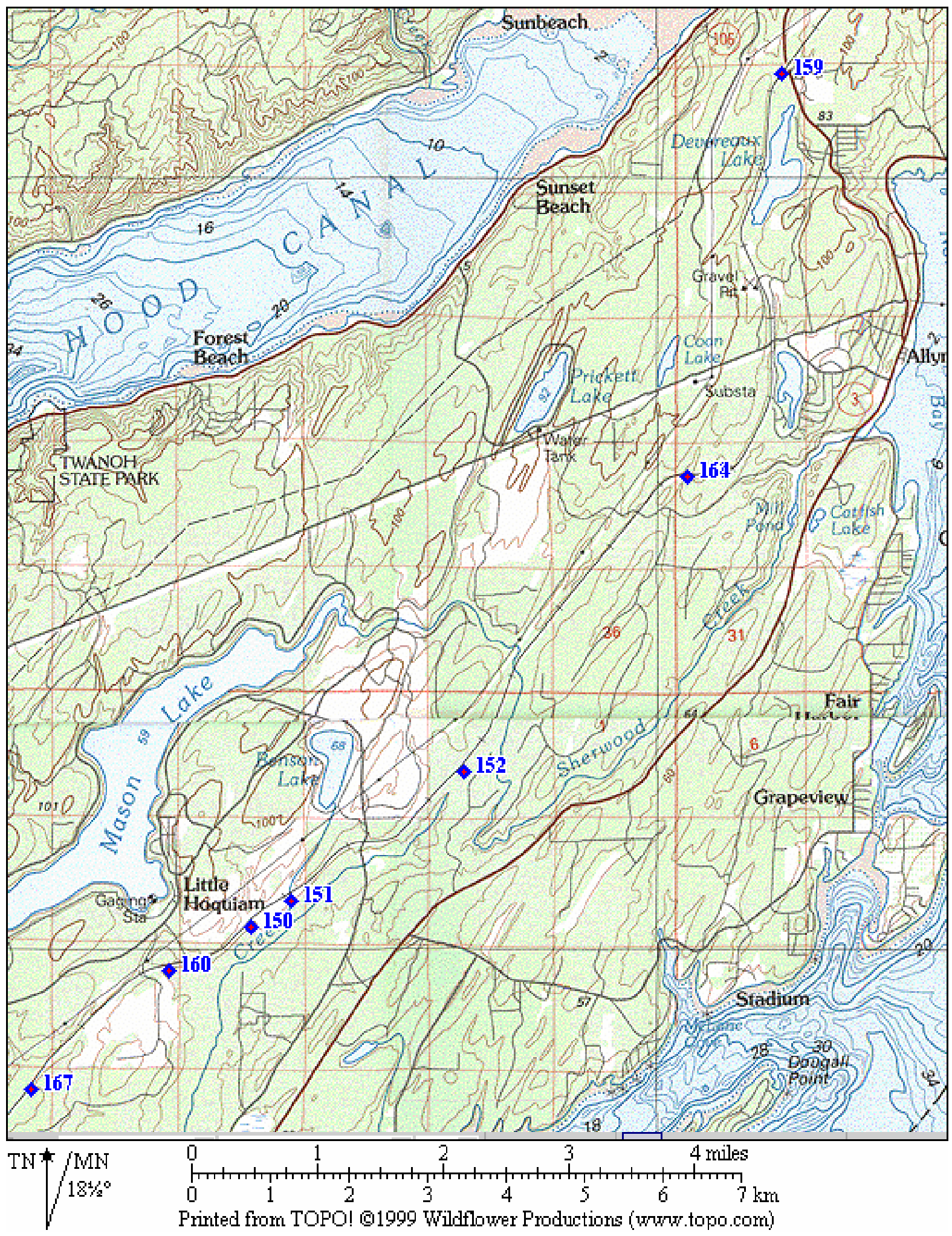

Figure 13. Map 2-Navy railroad line culvert locations. 
PSNS CULVERT SURVEY 2003

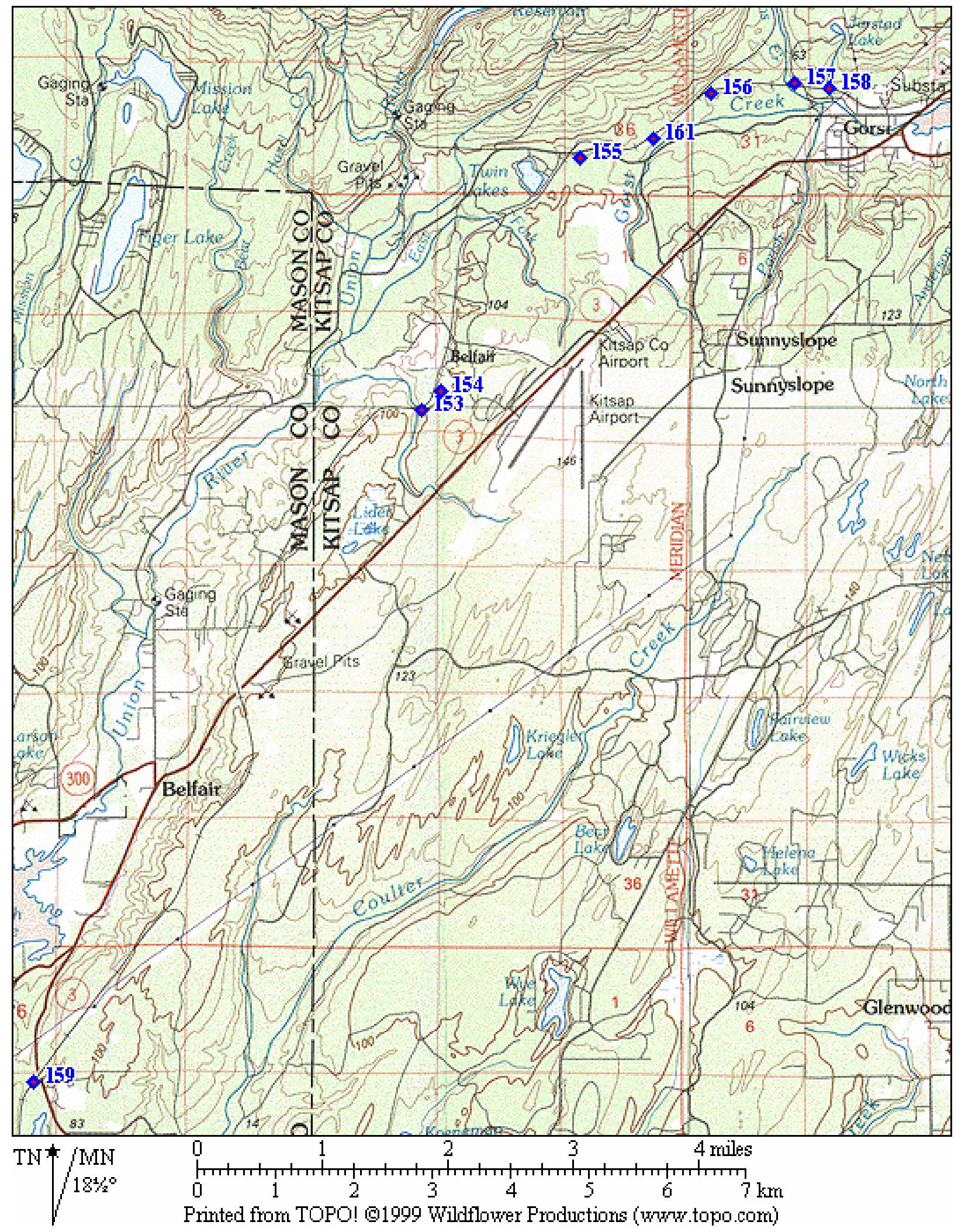

Figure 14. Map 3-Navy railroad line culvert locations.

Railroad Culvert Report

Puget Sound Naval Shipyard and Intermediate Maintenance Facility 


\section{$\underline{\text { RR MP 2.19 }}$ (Figures 15 and 16)}

This RR culvert is located at the headwaters of an unnamed stream (WRIA 14.0047) that drains into Oakland Bay near Shelton (Figure 12; WP 146). The stream channel appears to be perennial at this point in the watershed, originating in a forested wetland on the upstream side of the railroad grade. There is a natural barrier in the lower mainstem of this creek upstream of SR-3. In addition, the culvert under SR-3 appears to be a complete fish-passage barrier. The RR culvert was assessed as a complete barrier based on WDFW Level-A analysis (little natural streambed material inside the culvert, slope $>1 \%$, and outlet perched approximately $1 \mathrm{foot}$ ). The PI score is 6.43. No fish were observed in the stream during cuolvert surveys and the channel is listed as a Type 5 by WA-DNR. The stream is classified as potentially fishbearing based on the channel size and gradient criteria. The RR culvert is a 6-foot diameter (209 ft in length) reinforced concrete pipe (RCP) with an upstream trash rack made from railroad ties. This trash rack is a barrier to fish passage at the upstream end of the RR culvert. It is recommended that this rack be removed to allow the free flow of water and organic material through the culvert. In addition, the removal will eliminate the potential water quality problem of the creosote railroad ties being in the creek and will improve passage for water, sediment, organic material, and biota through the culvert.

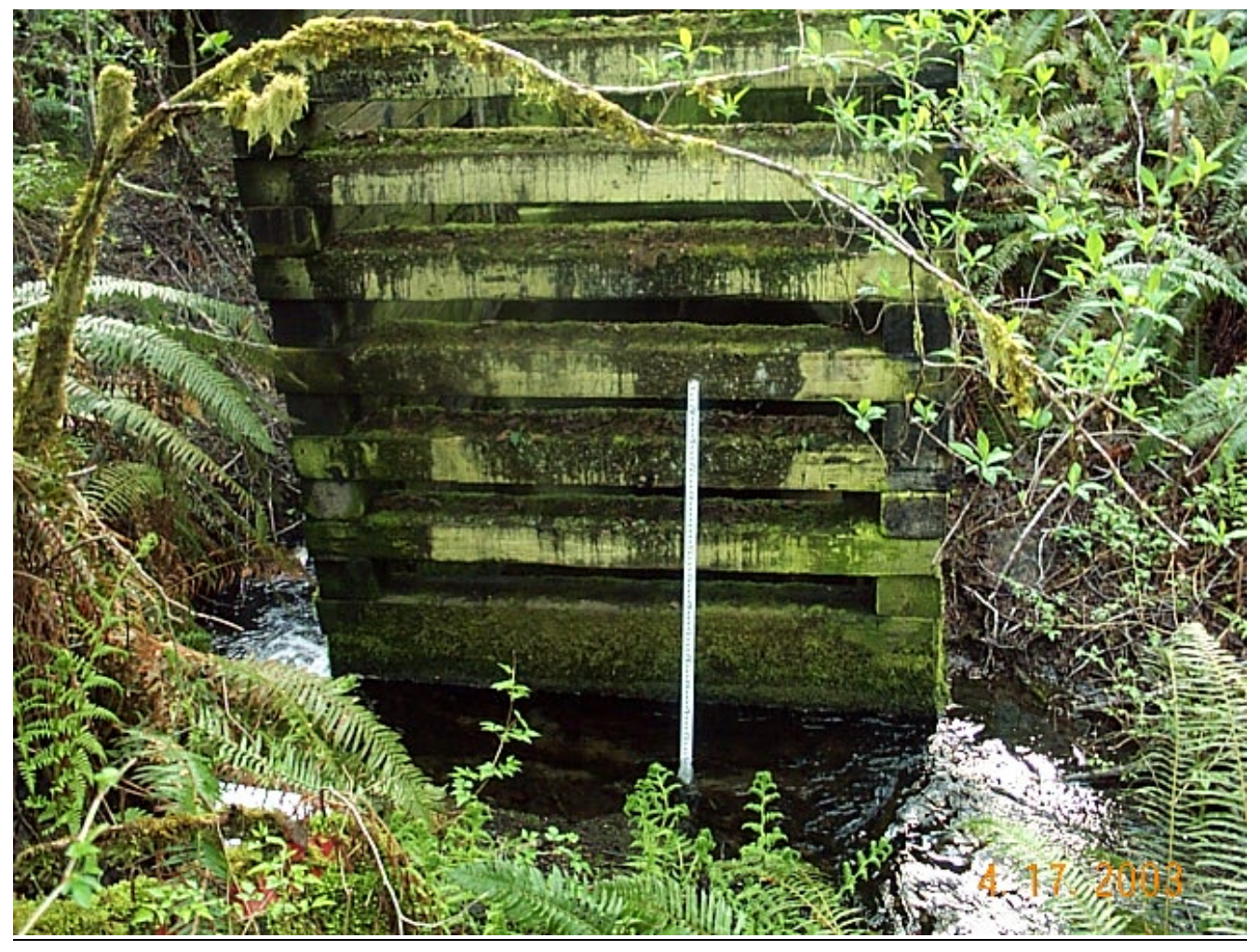

Figure 15. Existing trash rack on inlet of railroad culvert MP 2.19. 

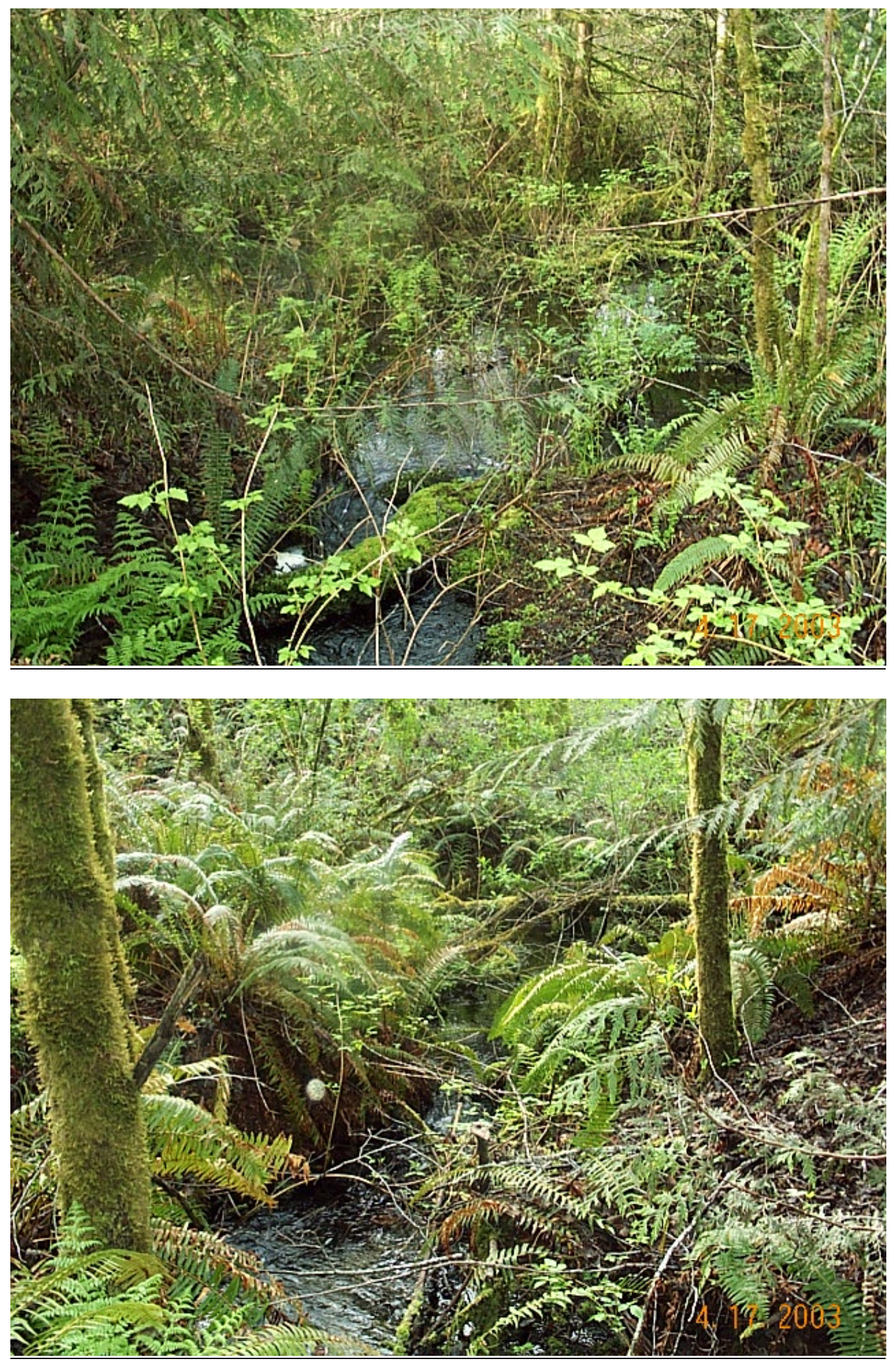

Figure 16. Riparian wetland upstream of railroad culvert MP 2.19. 


\section{$\underline{\text { RR MP 3.79 }}$ (Figure 17)}

This RR culvert is located on the mainstem of Johns Creek (WRIA 14.0049) northeast of Shelton (Figure 12; WP 162). The culvert is a double-box (8- by 5-ft) concrete culvert. One side is fitted with a fish ladder to allow for adult fish passage upstream. Because of the flat concrete floor of the culvert and the lack of natural streambed material through its length, the culvert is likely a partial barrier to juveniles during high- and low-flow conditions. The fish ladder appears to function adequately for upstream adult passage except for short periods during extreme flow events. The fish ladder meets WDFW criteria for adult fish passage. This culvert is not recommended for replacement at this time, but passage could possibly be enhanced for both adults and juveniles if the culvert could be modified to meet stream simulation guidelines with a more natural streambed (see WDFW 1999).

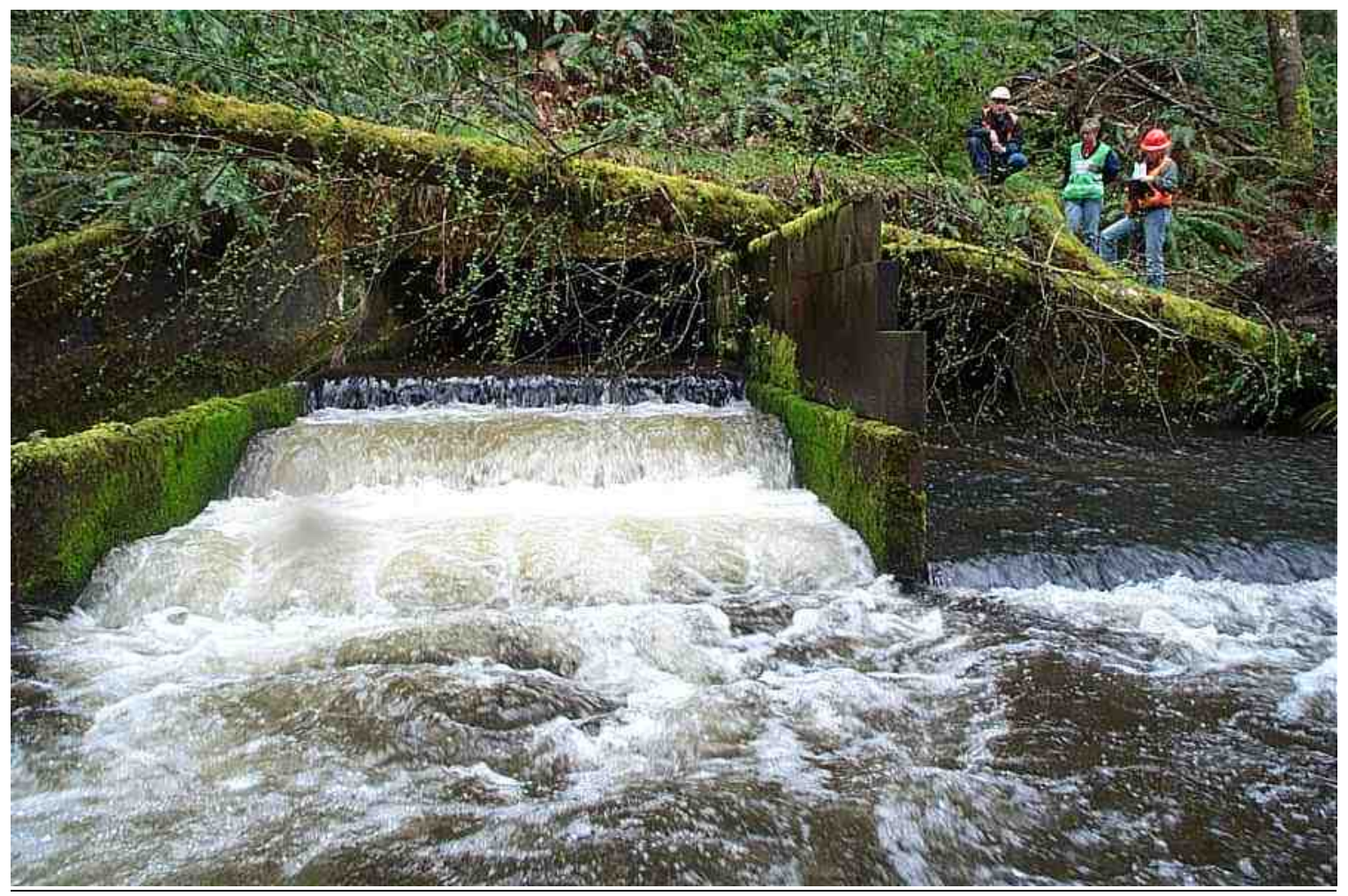

Figure 17. Johns Creek box culvert and fishway, railroad MP 3.79. 


\section{$\underline{\text { RR MP 6.60 }}$ (Figure 18)}

This RR culvert is located in the headwaters of Cranberry Creek (WRIA 14.0051) northeast of Shelton (Figure 12; WP 147). The culvert is a double-box (8- by 5-ft) concrete culvert. The culvert was assessed as passable during LFA surveys (WCC, 2002). No corrective action is needed for this RR culvert.

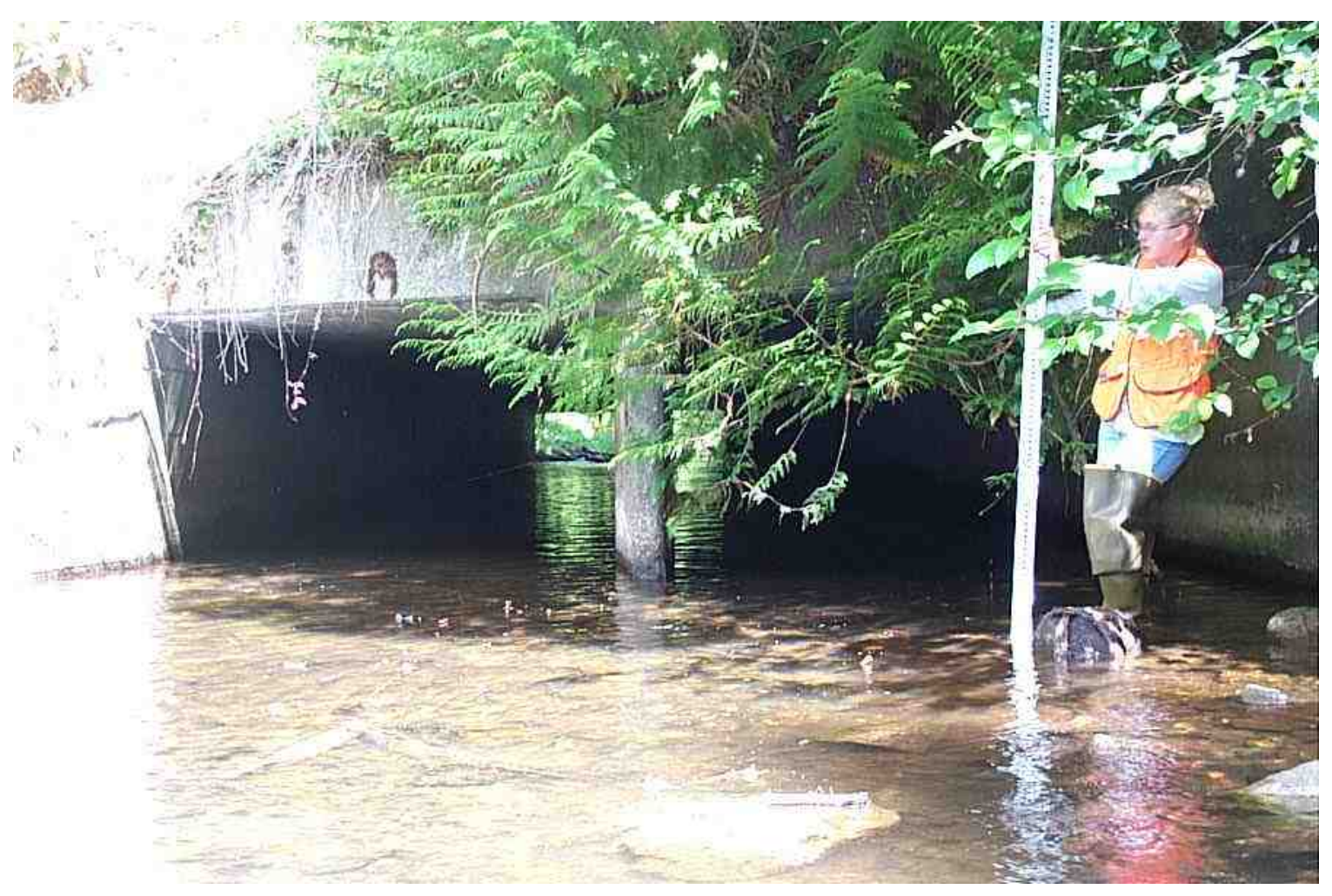

Figure 18. Cranberry Creek box culvert, railroad MP 6.60. 


\section{$\underline{\text { RR MP } 7.52}$ (Figure 19)}

This RR culvert is located on a headwater tributary of Cranberry Creek (WRIA 14.0052) northwest of Shelton (Figure 12; WP 165). The culvert is a 3-ft concrete pipe (125 ft in length). The stream channel appears to be seasonal at this point in the watershed, originating in a forested wetland on the upstream side of the railroad grade. The RR culvert was assessed as passable based on WDFW Level-A analysis (natural streambed material throughout the culvert, slope $<1 \%$, and adequate culvert diameter). However, the culvert may be a partial barrier during high and/or low flow periods. Therefore, a habitat assessment was conducted and a PI score of 6.73 was obtained for this culvert. No fish were observed in the stream, and the channel is listed as a Type 5 by WA-DNR. However, based on stream channel size the stream was classified as potentially fish-bearing

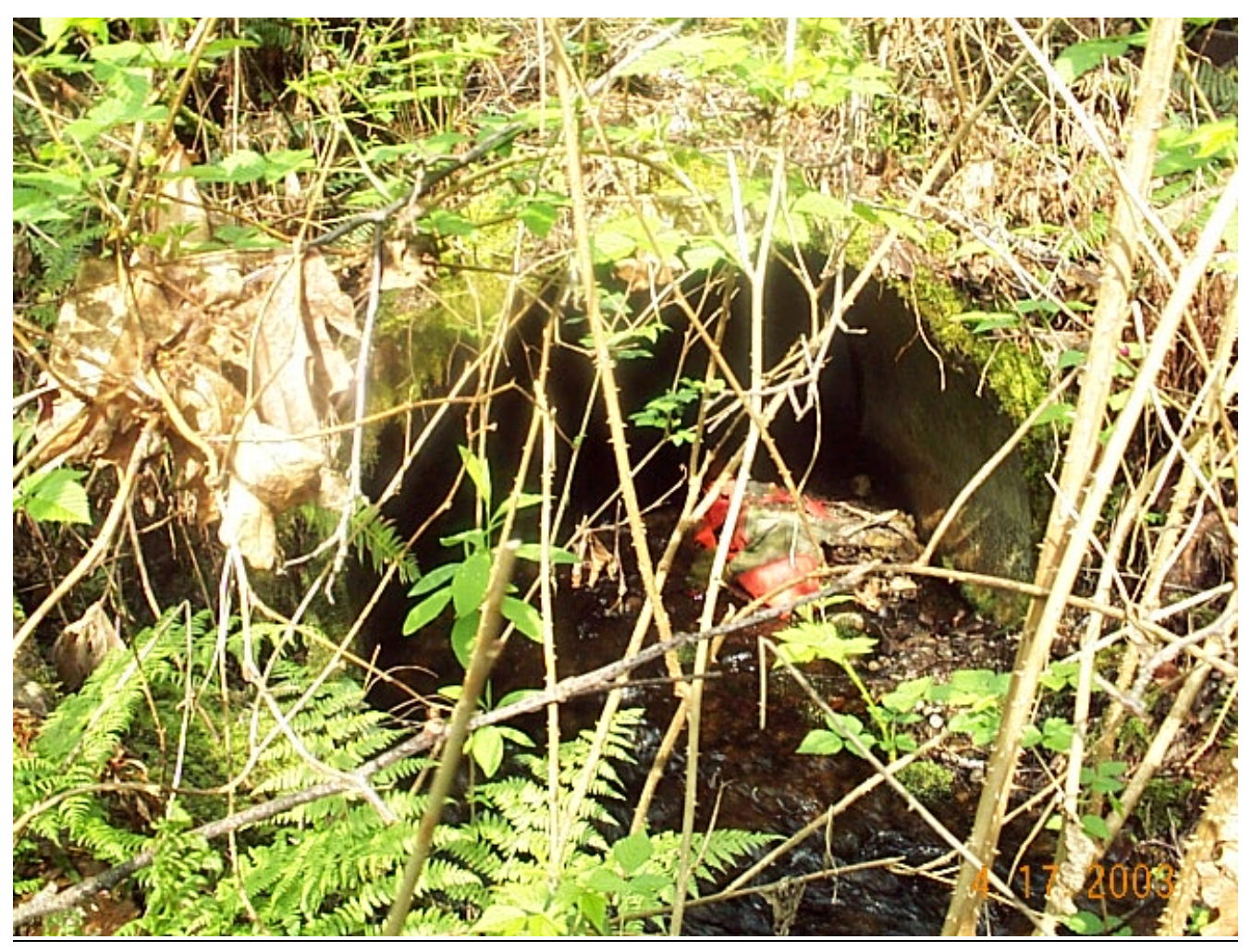

19. Outlet of railroad culvert MP 7.52. 
$\underline{\text { RR MP 8.90 }}$ (Figures 20 and 21)

This RR culvert is located on a headwater tributary of Deer Creek (no assigned WRIA number) northeast of Shelton (Figure 12; WP 149). The culvert is a 6-ft concrete pipe (323 ft in length) with an upstream trash rack made from railroad ties. This trash rack is a barrier to fish passage at the upstream end of the $\mathrm{RR}$ culvert. It is recommended that this railroad-tie trash rack be removed to allow the free flow of biota, water, and organic material through the culvert. In addition, the removal will eliminate the potential water quality problem of the creosote railroad ties being in the creek and will allow for more unrestricted passage for fish, amphibians, and wildlife through the culvert. The RR culvert was assessed as passable based on WDFW Level-A analysis (natural streambed material throughout the culvert, slope $<1 \%$, and adequate culvert diameter). However, the culvert may be a partial barrier during high and/or low flow periods. Therefore, a habitat assessment was conducted and a PI score of 7.32 was obtained for this culvert. Habitat assessment surveys downstream of the railroad culvert indicate extensive wetlands and beaver ponds interspersed with stream channels. Passage through this area is likely seasonal and very dependent on flow conditions and beaver activity. Upstream of the culvert, the habitat is dominated by forested wetlands and beaver ponds, which could provide rearing habitat for both cutthroat and coho. Although no fish were observed during culvert surveys, the stream is still classified as potentially fishbearing based on channel width and existing habitat.

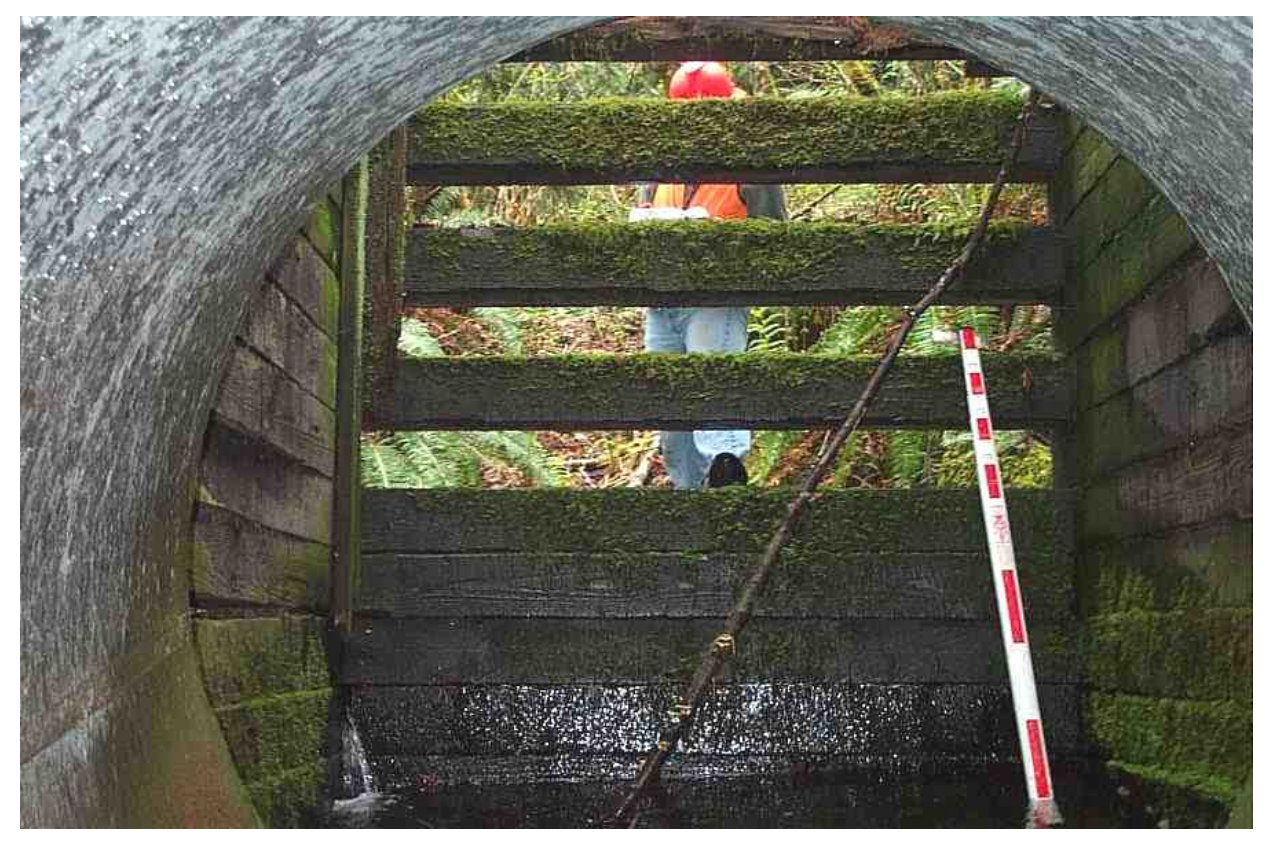

Figure 20. Trash rack on inlet of railroad culvert MP 8.90. 

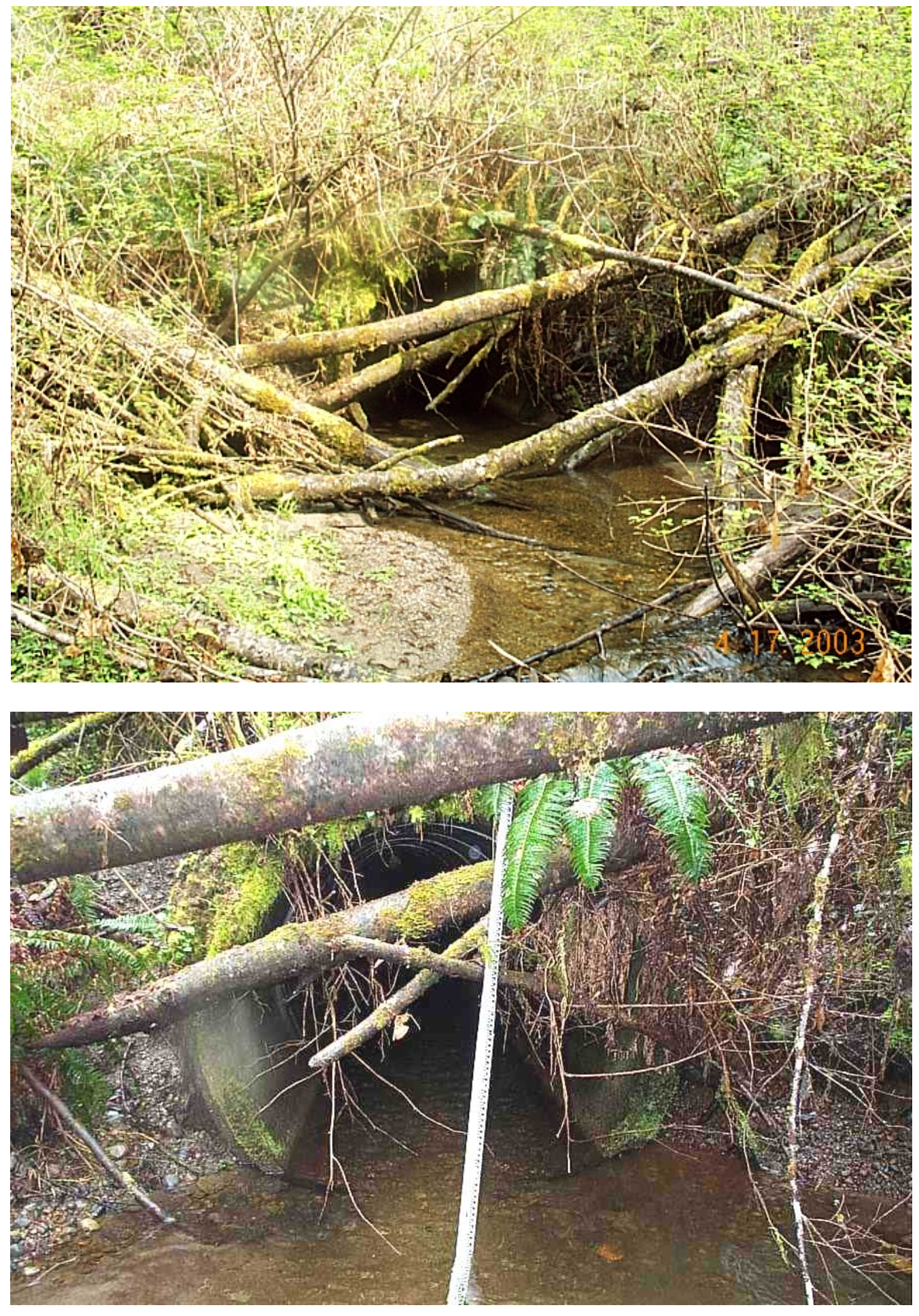

Figure 21. Outlet of railroad culvert MP 8.90. 


\section{$\underline{\text { RR MP 9.28 }}$ (Figure 22)}

This RR culvert is located on a headwater tributary of Deer Creek (no assigned WRIA number) northeast of Shelton (Figure 12; WP 166). The culvert is a 4-ft concrete pipe (300 ft in length). The stream channel appears to be seasonal at this point in the watershed, originating in a forested wetland on the upstream side of the railroad grade. The RR culvert was assessed as passable based on WDFW Level-A analysis (natural streambed material throughout the culvert, slope $<1 \%$, and adequate culvert diameter). However, the culvert may be a partial barrier during high and/or low flow periods. Therefore, a habitat assessment was conducted and a PI score of 7.12 was obtained for this culvert. No fish were observed in the stream during culvert surveys and the channel is listed as a Type 5 by WA-DNR, however the stream was classified as potentially fish-bearing based on channel size. There is a trash rack made from railroad ties located on the upstream end of the RR culvert. This trash rack is a barrier to fish passage at the upstream end of the RR culvert. It is recommended that this railroad-tie trash rack be removed to allow the free flow of biota, water, and organic material through the culvert. In addition, the removal will eliminate the potential water quality problem of the creosote railroad ties being in the creek and will allow for more unrestricted passage for fish, amphibians, and wildlife through the culvert.

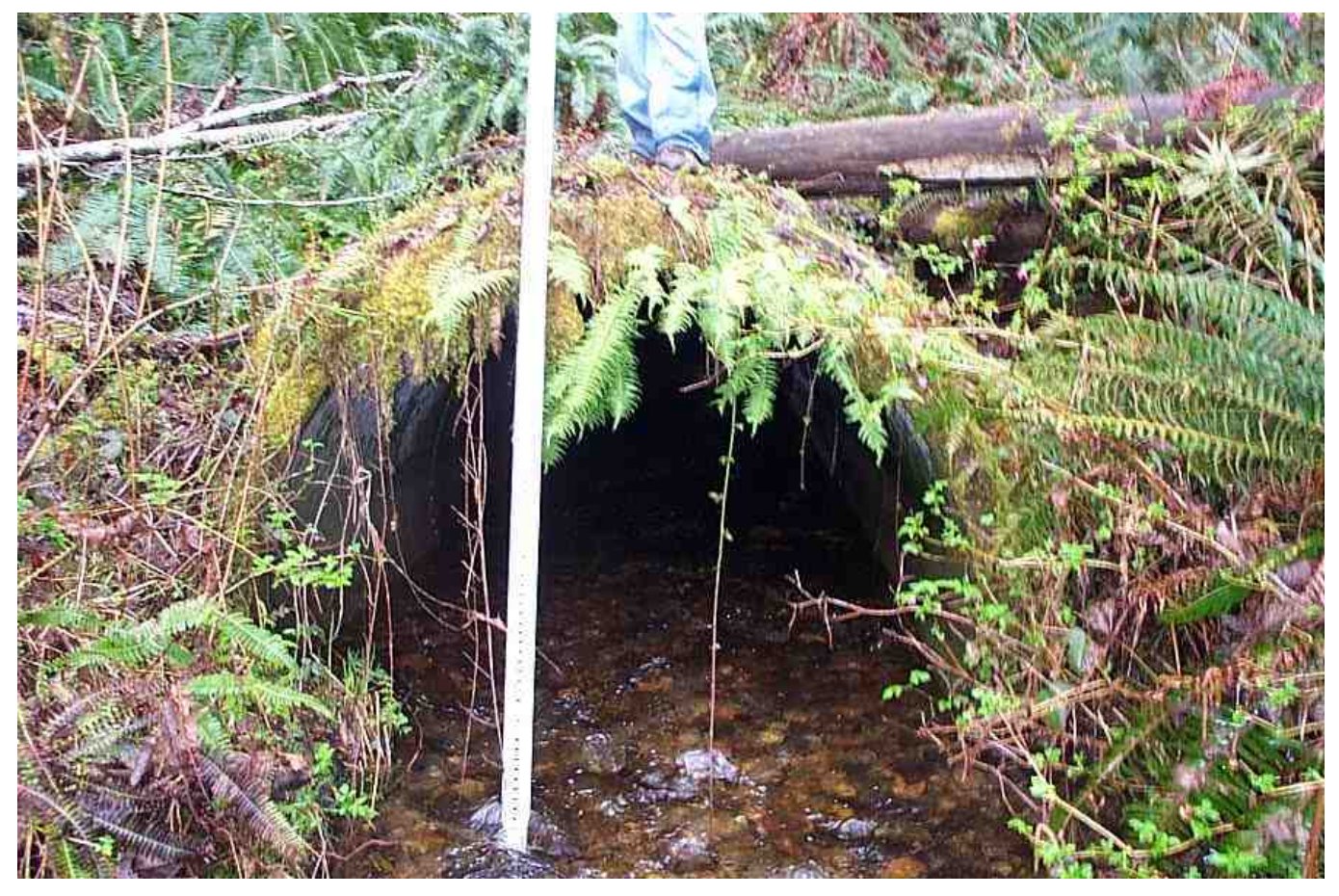

Figure 22. Outlet of railroad culvert MP 9.28 


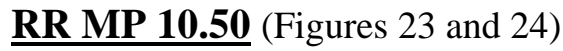

This RR culvert is located on a headwater tributary of Deer Creek (no assigned WRIA number) northeast of Shelton (Figure 12; WP 167). The culvert crossings consist of twin (3-ft) concrete pipes (100 ft in length) approximately 400 feet apart. The stream channel originates form an extensive beaver pond wetland located on the upstream side of the railroad grade (see Figure 22). Very little water was flowing in the culverts or the downstream channels at the time of the survey, although there was water in the upstream beaver pond wetland. The RR culverts were assessed as passable based on WDFW Level-A analysis (natural streambed material throughout the culvert, slope $<1 \%$, and adequate culvert diameter). However, because there are two relatively small culverts located at this crossing and because of the presence of beaver activity, these culverts may be partial barriers during some flow conditions or when beaver activity causes a blockage of one or both culverts. No fish were observed in the stream, however the stream should be considered potentially fish-bearing based on existing habitat conditions and stream channel size. Determination of resident salmonid use of the upstream beaver pond wetland would require additional surveys of the downstream channel and upstream wetlands. Stream habitat assessments were conducted and a PI score of 6.55 was determined. The RR culverts were classified as passable based on WDFW Level-A analysis (natural streambed material throughout the culvert, slope $<1 \%$, and adequate culvert diameter). However, the beaver pond location at the inlet of the railroad culverts is problematic from both a passage and maintenance perspective. It is recommended that a "beaver deceiver" device (Appendix B) be constructed at the culvert inlets to prevent beaver activity from reducing culvert capacity and restricting passage. These installations are designed to allow unrestricted flow through the culverts, as well as fish passage, while preventing the beaver from damming the culvert inlets. These devices do require special operational and maintenance efforts to ensure fish passage.

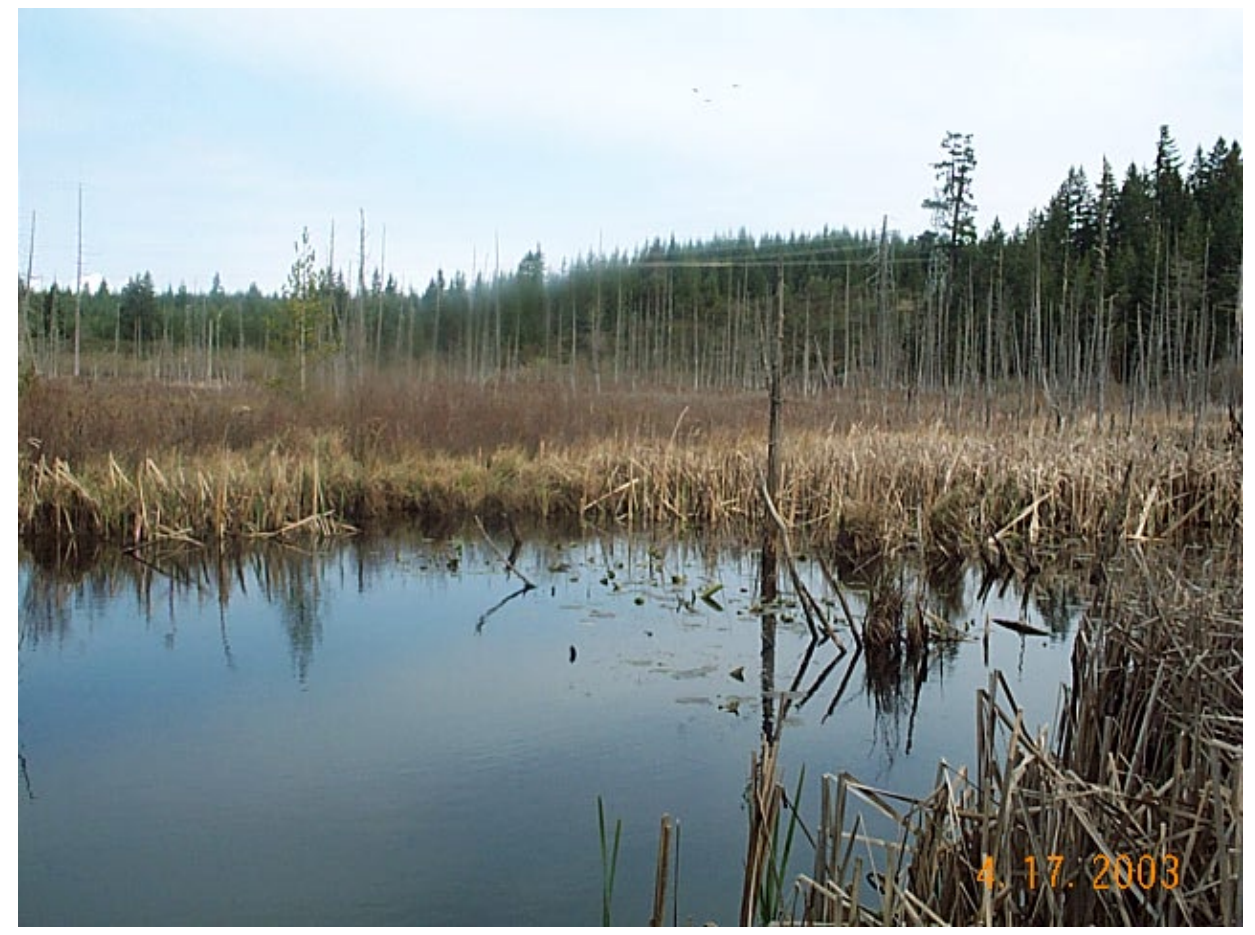

Figure 23. Beaver pond at inlet of railroad culvert MP 10.50. 


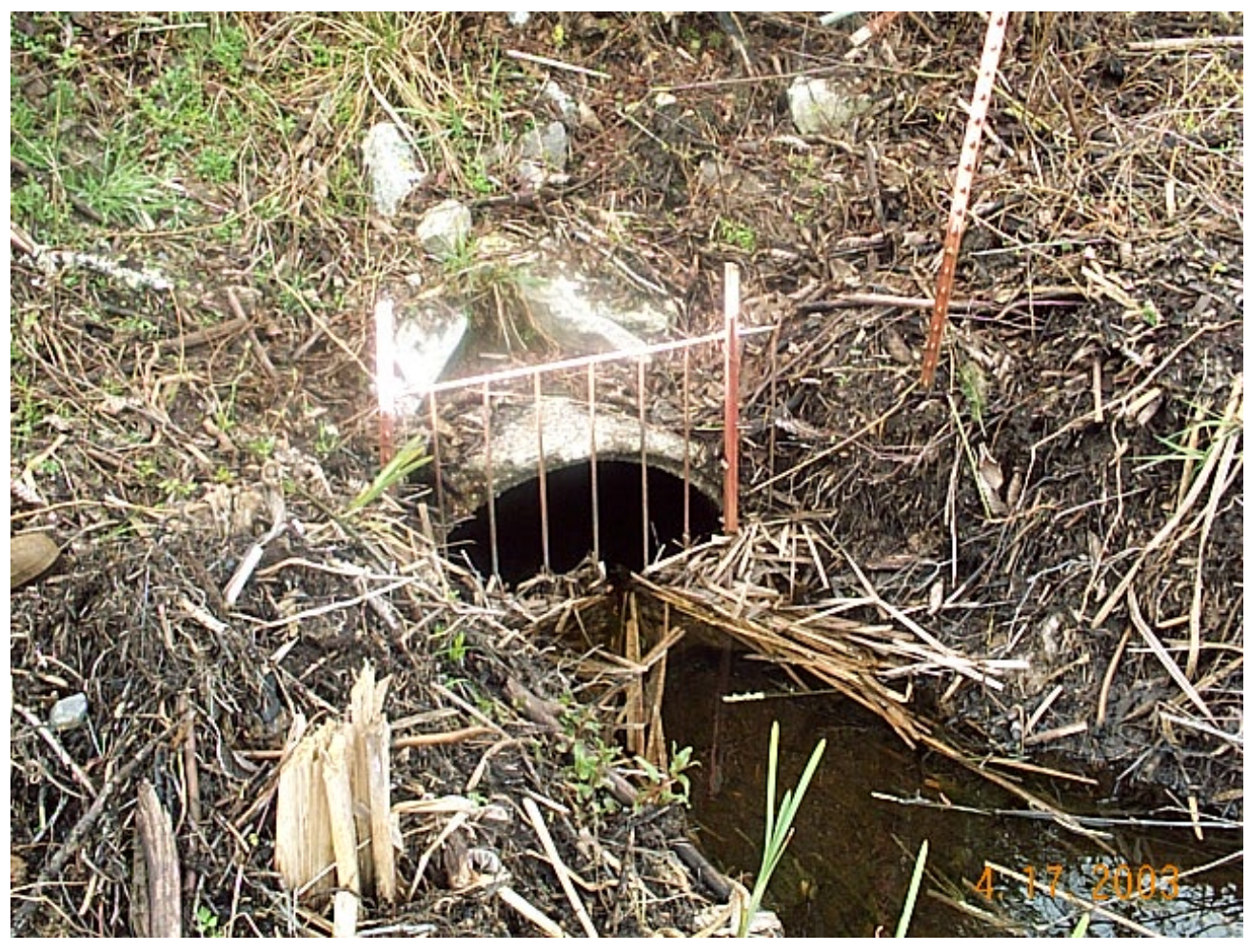

Figure 24. Inlet of railroad culvert MP 10.50. 


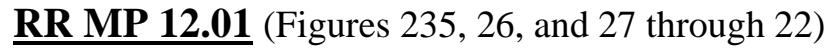

This RR culvert is located on a headwater tributary of Deer Creek (WRIA 14.0060) northeast of Shelton (Figure 13; WP 160). The culvert is a 5-ft concrete pipe (258 ft in length). The stream channel appears to be perennial at this point in the watershed, originating in a beaver pond wetland on the upstream side of the railroad grade. Very little water was flowing in the culvert or the downstream channel at the time of the survey, although there was water in the upstream beaver pond wetland. No fish were observed in the stream. There may be salmonid use of the upstream beaver pond wetland, but this study was not able to make that determination. Therefore, the stream was calssified as potentially fish-bearing. There are also wetlands, beaver ponds, and signs of beaver activity downstream of the railroad culvert. The stream system can be described as a series of interconnected headwater wetlands at this point in the watershed. The RR culvert was assessed as passable based on WDFW Level-A analysis (natural streambed material throughout the culvert, slope $<1 \%$, and adequate culvert diameter).Although passable, the existing beaver activity may lead to periodic culvert blockages during some flow conditions. Therefore, a habitat assessment was conducted and a PI score of 7.45 was determined. The beaver pond location at the inlet and outlet of the RRculvert is problematic from both a passage and maintenance perspective. It is recommended that a "beaver deceiver" device (Appendix B) be constructed at the culvert inlet to prevent beaver activity from reducing culvert capacity and restricting passage. These installations are designed to allow unrestricted flow through the culvert, as well as fish passage, while preventing the beaver from damming the culvert inlet. The culvert outlet should also be cleared of debris and monitored for debris accumulation in the future. An additional beaver deterent device may be required on the outlet as well.

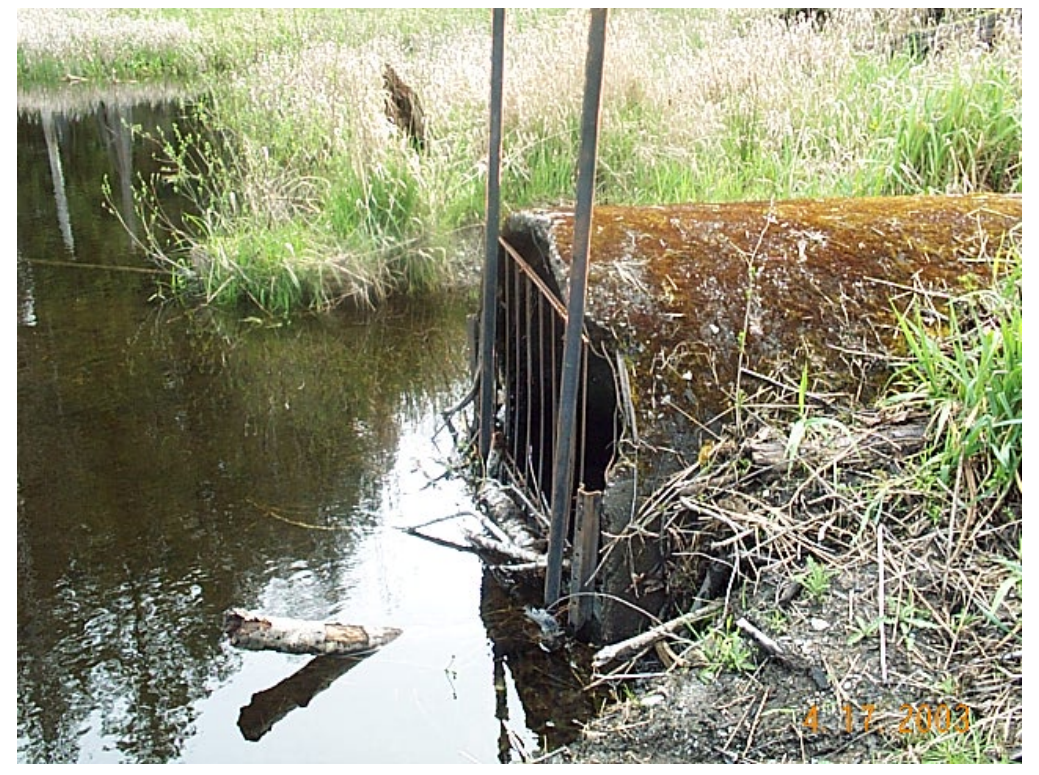

Figure 25. Existing inlet of railroad culvert MP 12.01. 

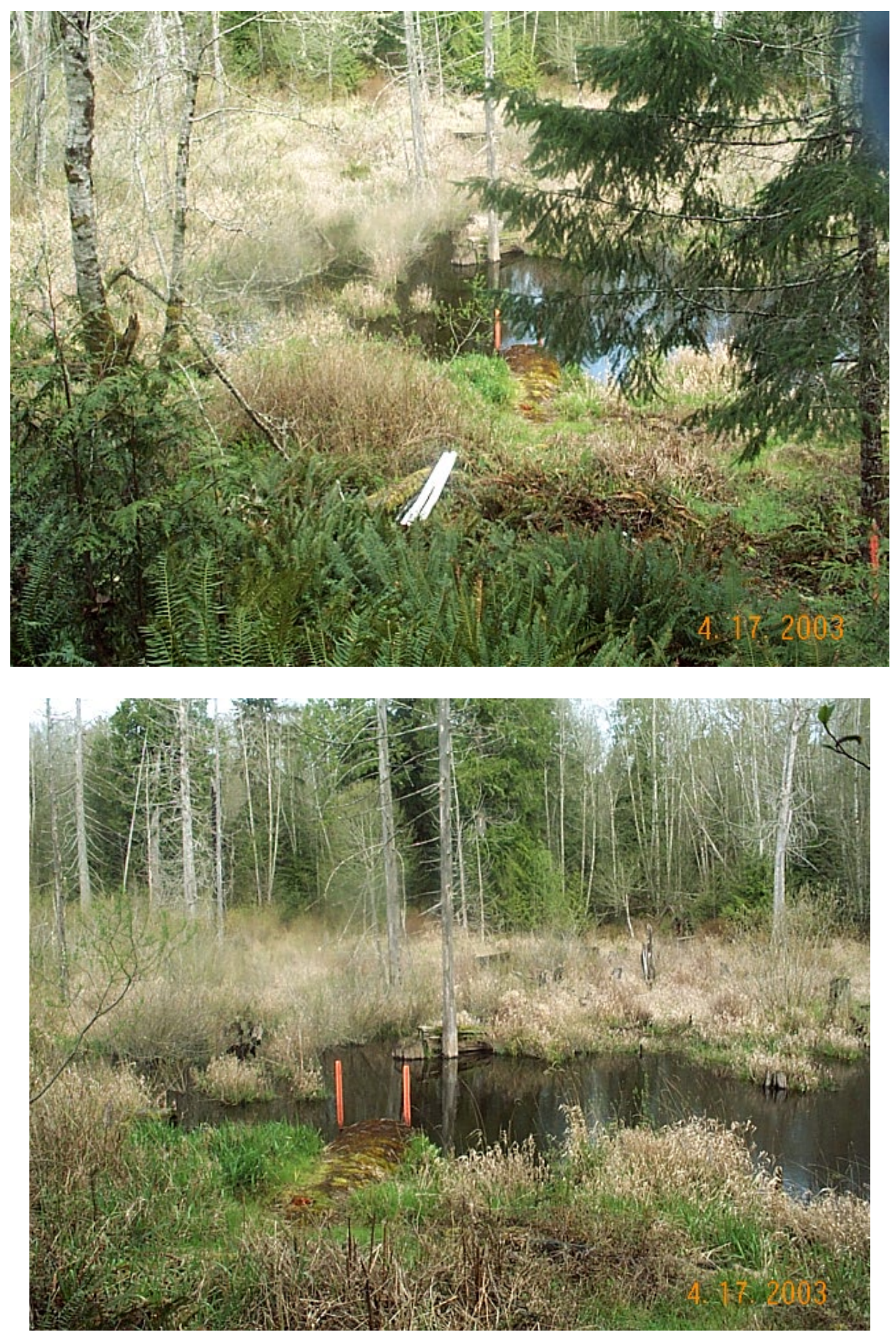

Figure 26. Beaver pond wetland at inlet of railroad culvert MP 12.01. 

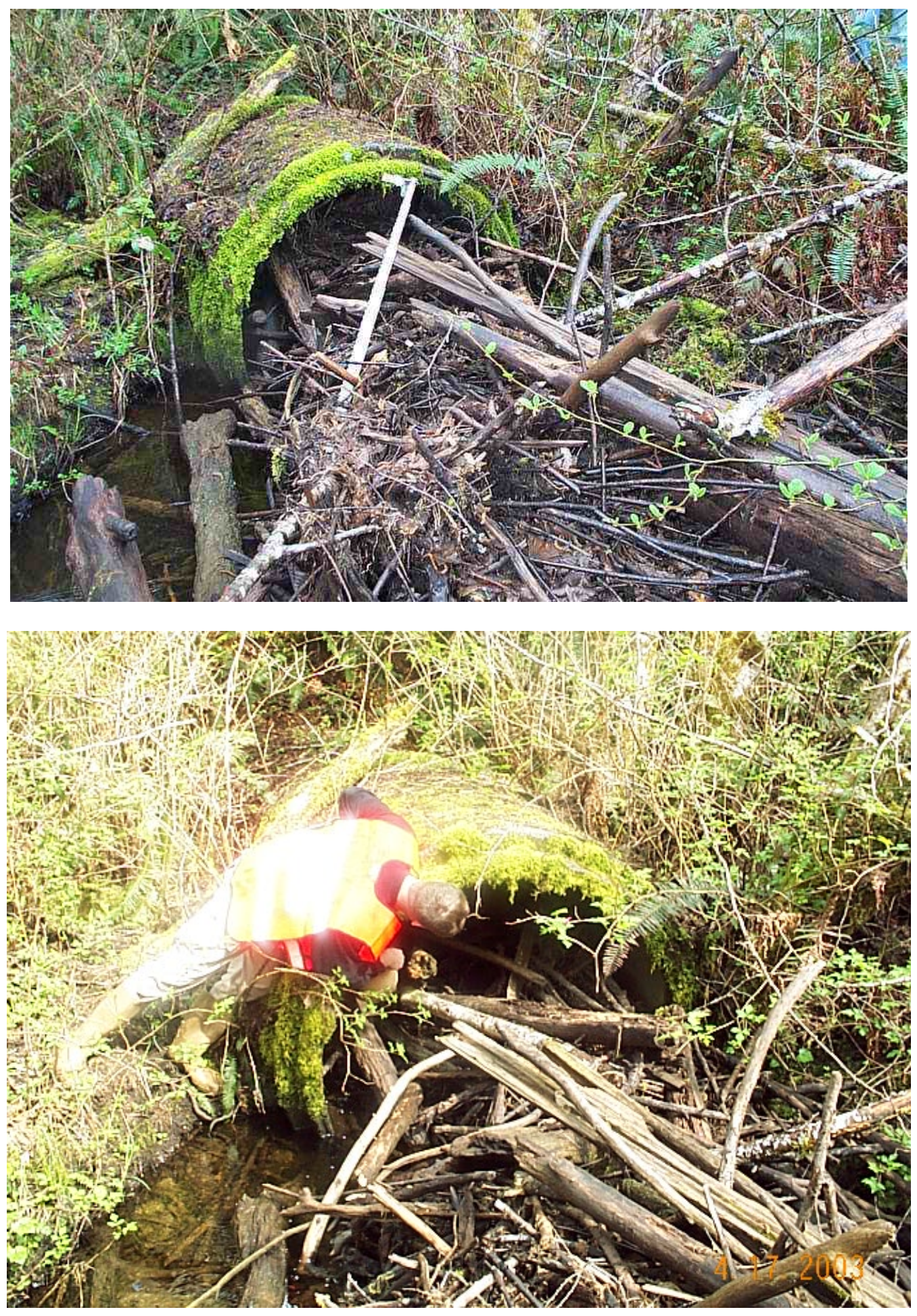

Figure 27. Outlet of railroad culvert MP 12.01. 
$\underline{\text { RR MP } 12.73}$ (Figures 28 and 29)

This culvert is located on a headwater tributary of Deer Creek (WRIA 14.0061) northeast of Shelton (Figure 13; WP 150). The culvert is a 4-ft concrete pipe (113 ft in length). The stream channel appears to be perennial at this point in the watershed, originating in a forested wetland on the upstream side of the railroad grade. The RR culvert was assessed as a complete barrier based on WDFW Level-A analysis (little natural streambed material inside the culvert, slope $>1 \%$, and outlet perched approximately 1 foot). The PI score is 8.59. No fish were observed in the stream during culvert surveys and the channel is listed as a Type 5 by WA-DNR, however, the stream is classified as potentially fish-bearing based on the channel size and gradient criteria. Determination of resident or anadromous salmonid use would require additional surveys of the downstream channels and upstream wetlands.

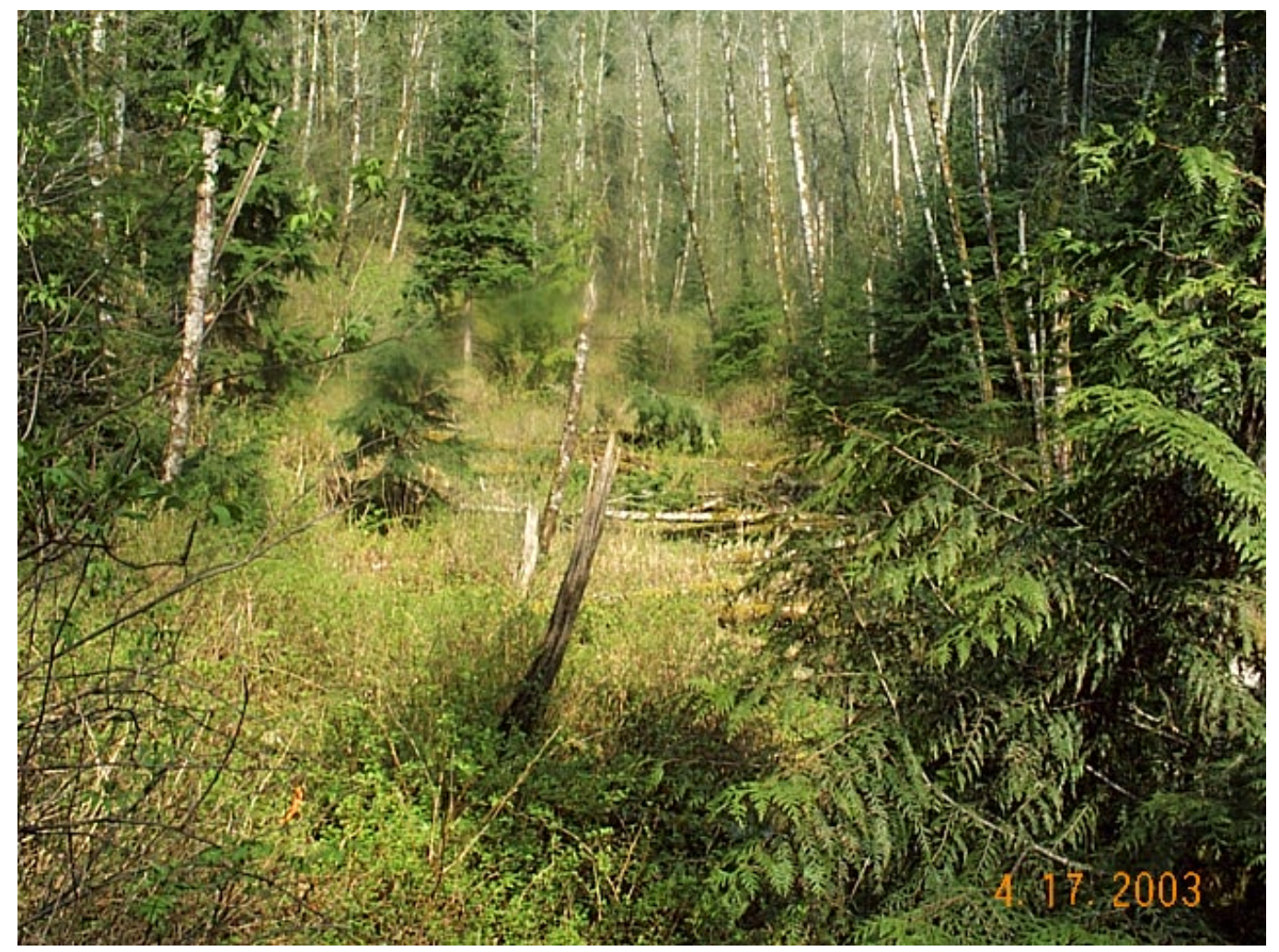

Figure 28. Upstream wetland at railroad culvert MP 12.73. 


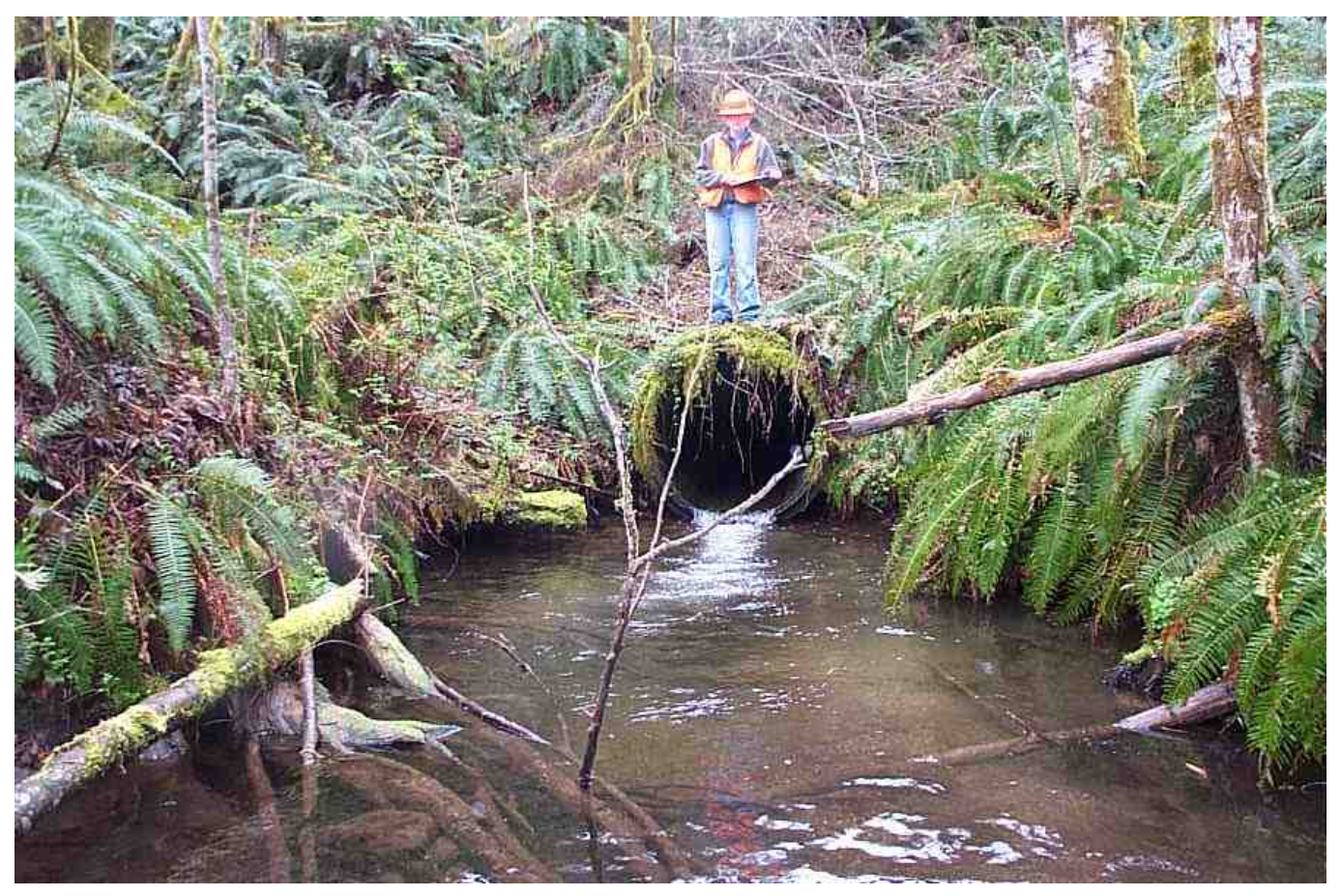

Figure 29. Outlet of railroad culvert MP 12.73. 
$\underline{\text { RR MP } 13.10}$ (Figures 30, 31, and 32)`

This RR culvert is located on a headwater tributary of Deer Creek (WRIA 14.0065) northeast of Shelton (Figure 13; WP 151). The culvert is a 6-ft concrete pipe (134 ft in length). The stream channel appears to be perennial at this point in the watershed, originating in a forested wetland and an abandoned beaver pond on the upstream side of the railroad grade. The RR culvert was assessed as passable based on WDFW Level-A analysis (natural streambed material throughout the culvert, slope $<1 \%$, and adequate culvert diameter). The culvert has an upstream trash rack made from railroad ties. This trash rack is a barrier for fish passage upstream of the culvert. It is recommended that this railroad-tie trash rack be removed to allow the free flow of water and organic material through the culvert. Removal of these ties will also eliminate the potential water quality problem of the creosote railroad ties being in the creek, and will further allow more unrestricted passage of fish, amphibians, and wildlife through the culvert. Although no fish were observed in this channel during culvert surveys, the creek is still considered to be potentially fish-bearing. Therefore, a habitat assessment was conducted and a PI score of 8.16 was determined.

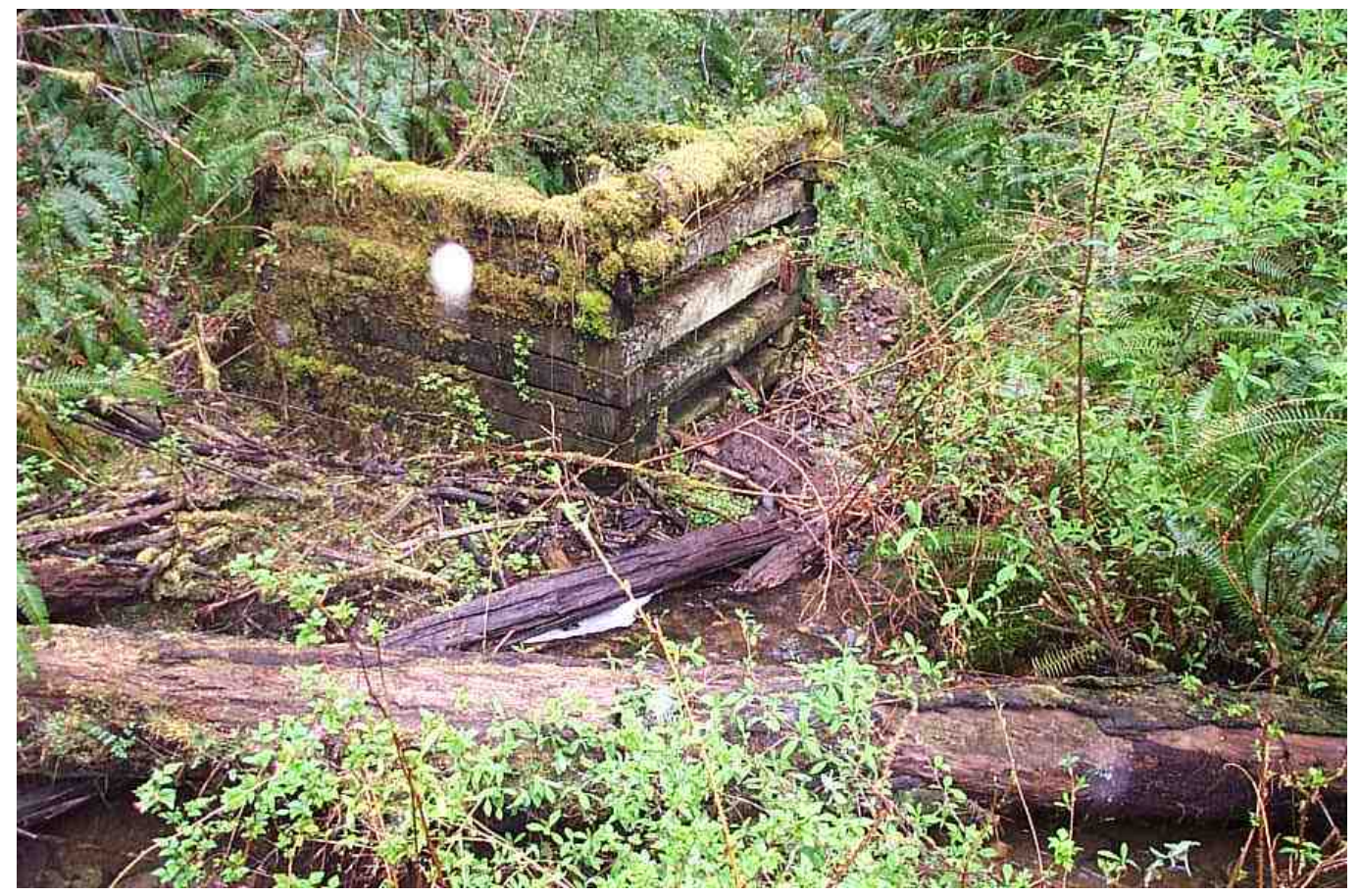

Figure 30. Trash rack at inlet of railroad culvert MP 13.10. 


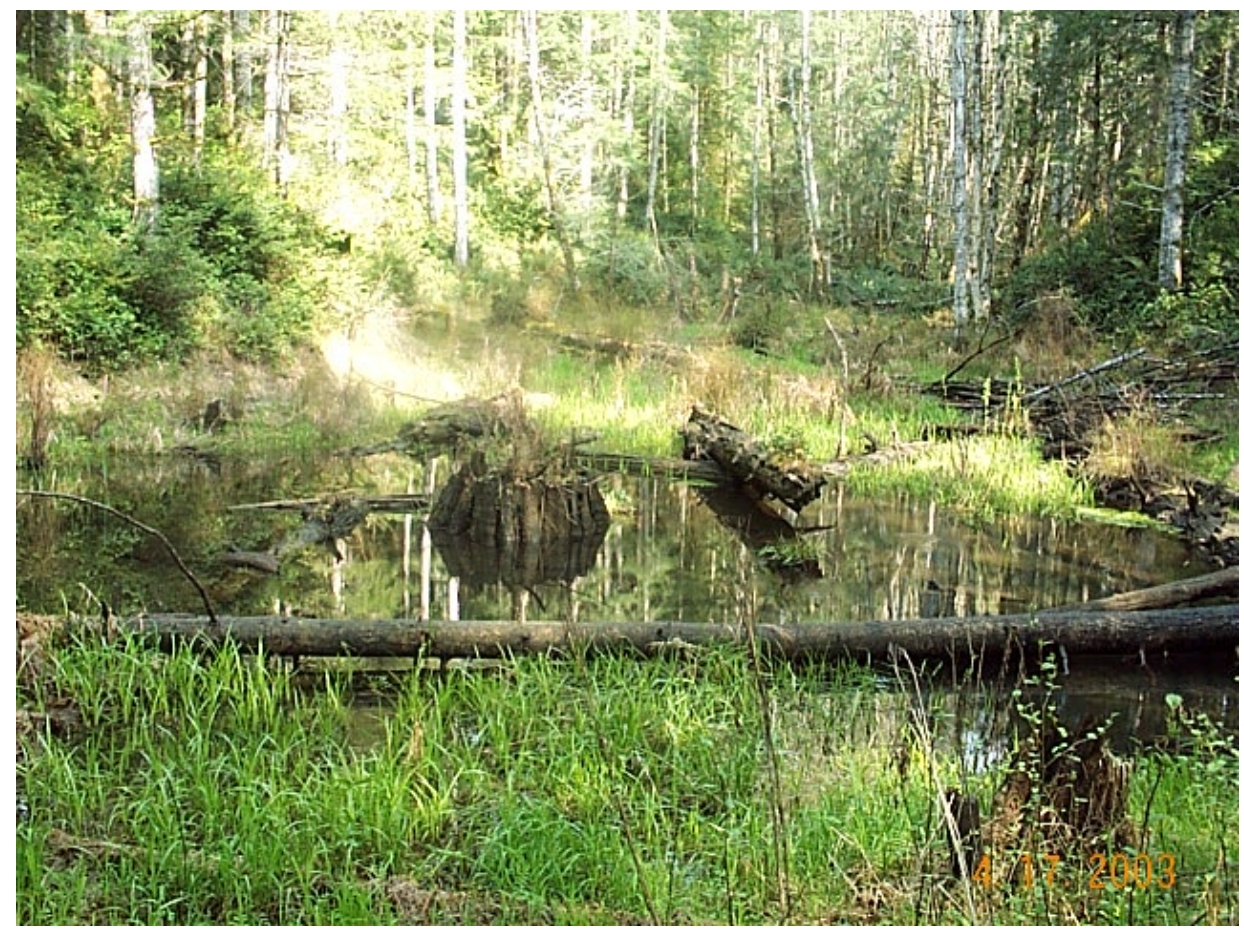

Figure 31. Upstream abandoned beaver pond at railroad culvert MP 13.10.

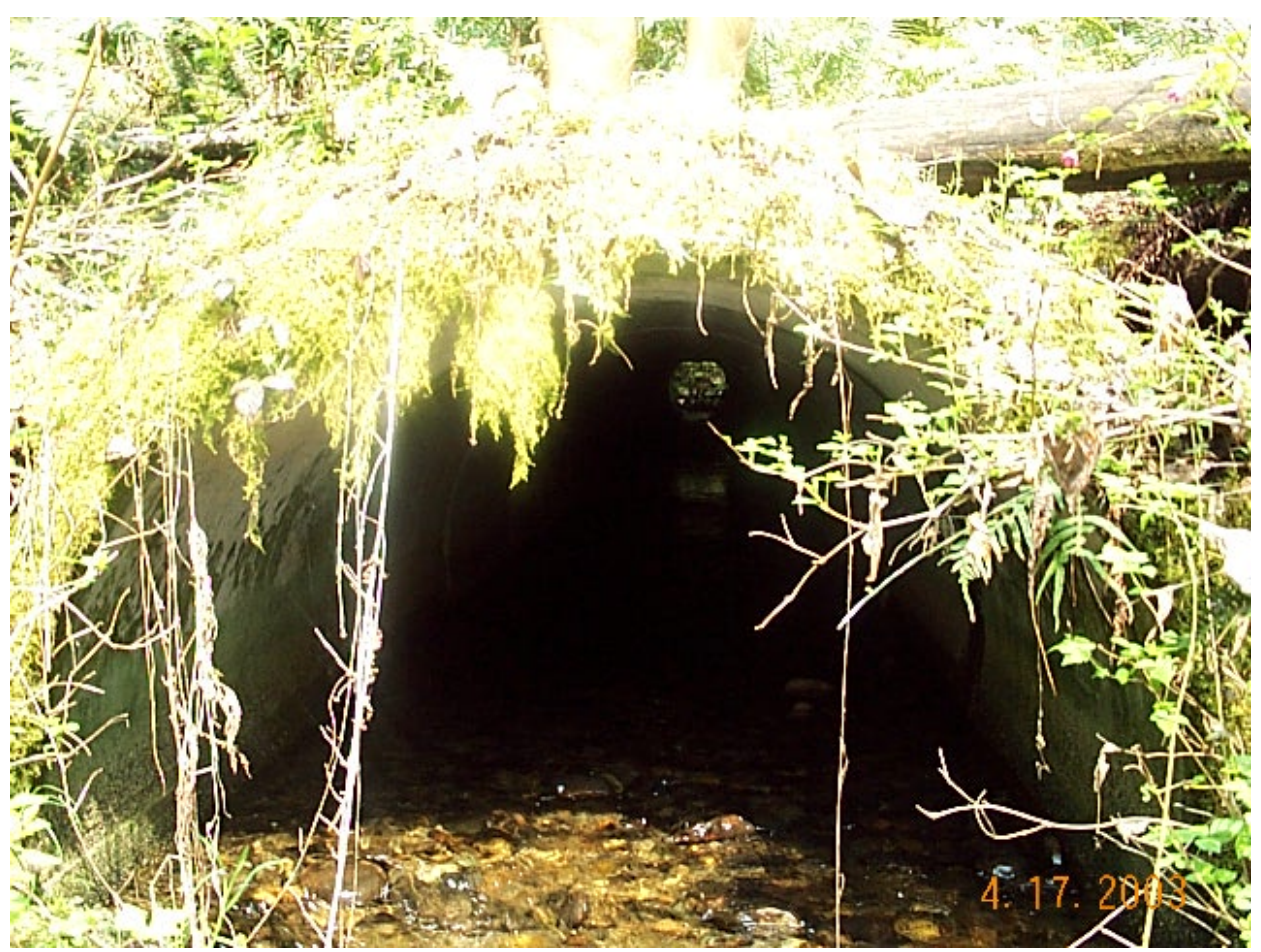

Figure 32. Outlet of railroad culvert MP 13.10. 


\section{$\underline{\text { RR MP 14.89 }}$ (Figures 33 and 34)}

This RR culvert is located on a headwater tributary of Deer Creek (WRIA 14.0066) northeast of Shelton (Figure 13; WP 152). The culvert is a 4-ft concrete pipe (100 ft in length). The stream channel appears to be perennial at this point in the watershed, originating in a beaver pond wetland on the upstream side of the railroad grade. There is also a beaver pond wetland located on the downstream end of the culvert. The RR culvert was assessed as passable based on WDFW Level-A analysis (natural streambed material throughout the culvert, slope $<1 \%$, and adequate culvert diameter). However, the beaver pond location at the inlet of the railroad culvert is problematic from both a passage and maintenance perspective. It is recommended that a "beaver deceiver" device (Appendix B) be constructed at the culvert inlet to prevent beaver activity from reducing culvert capacity and restricting passage. These installations are designed to allow unrestricted flow through the culvert, as well as fish passage, while preventing the beaver from damming the culvert inlet.

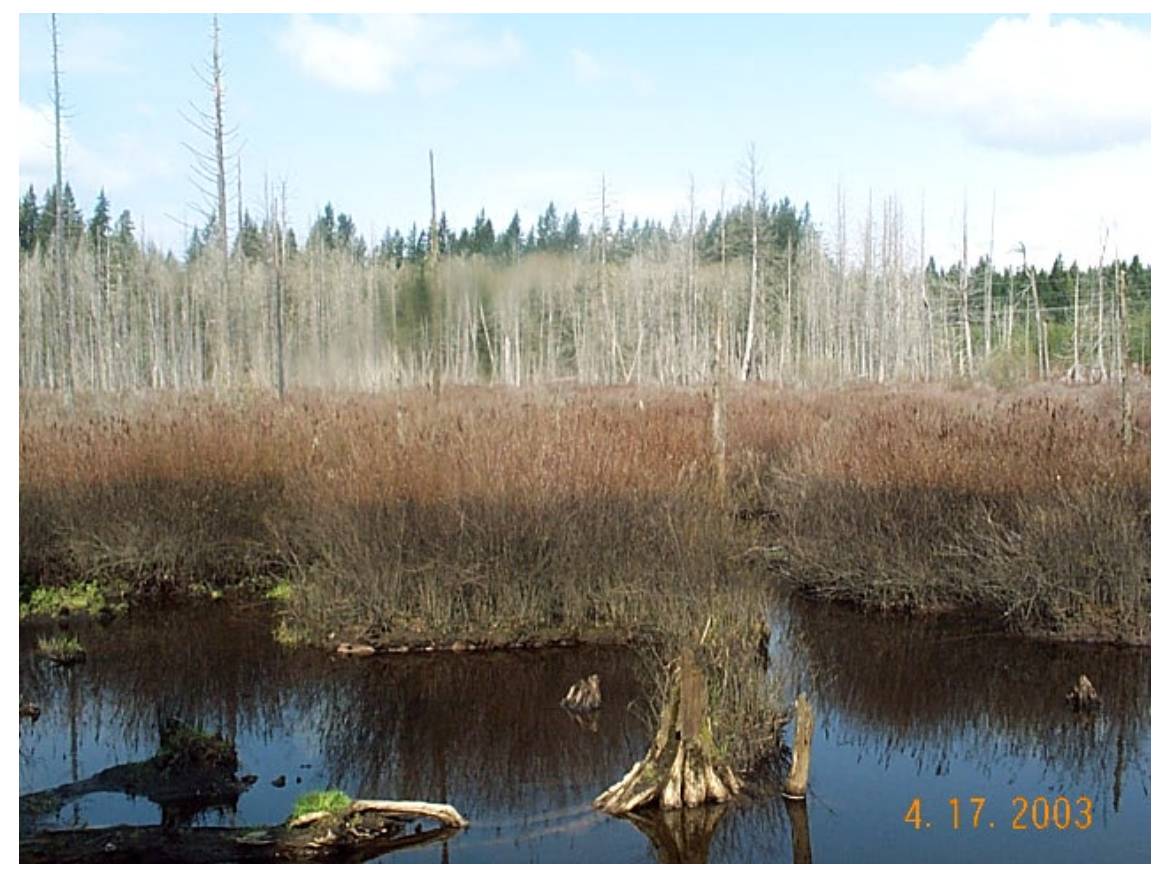

Figure 33. Beaver pond wetland at inlet of railroad culvert MP 14.89. 

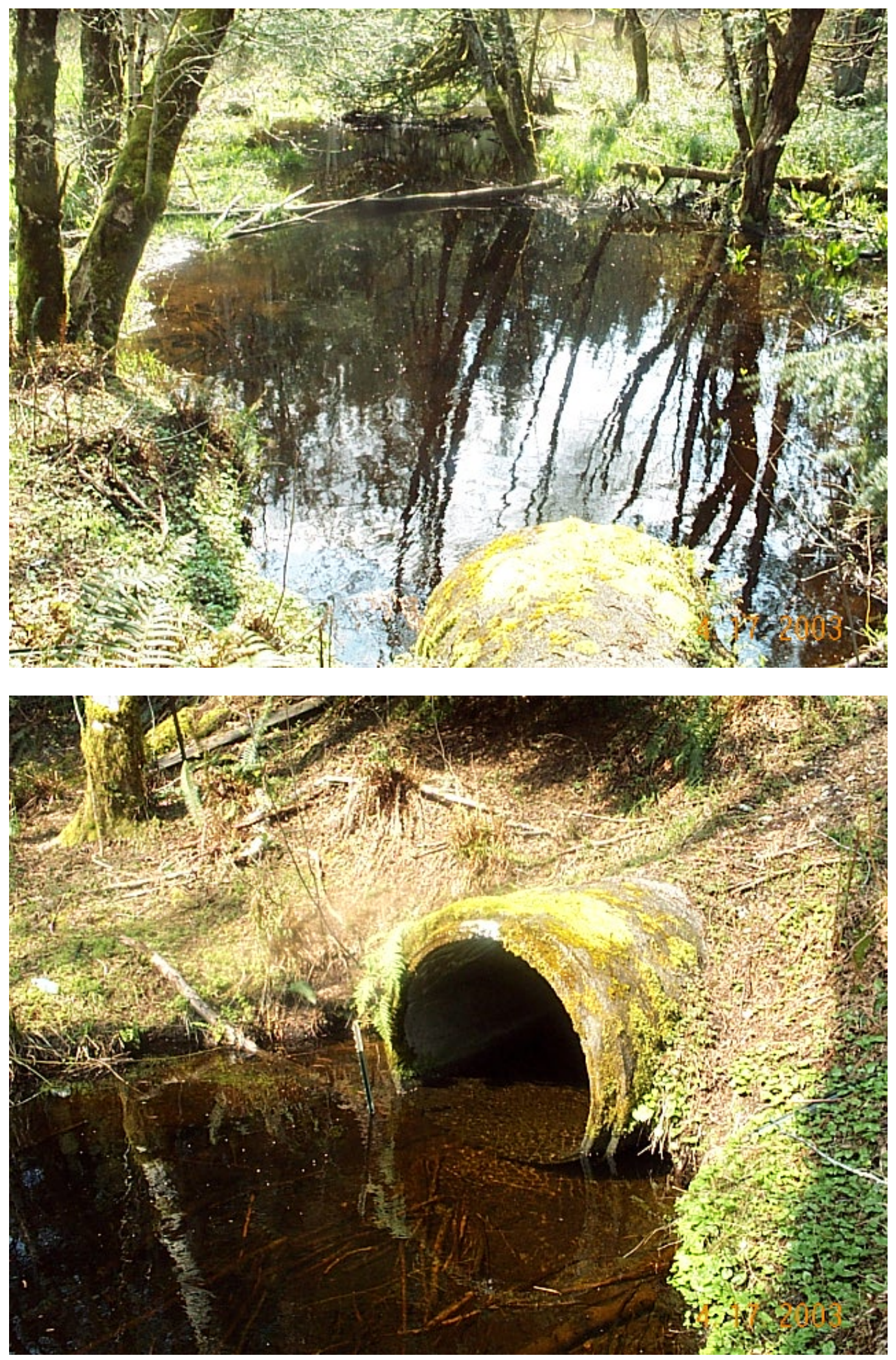

Figure 34. Beaver pond wetland at outlet of railroad culvert MP 14.89. 


\section{$\underline{\text { RR MP } 17.84}$}

This RR culvert is located on a headwater tributary of Sherwood Creek (no assigned WRIA number) northwest of Allyn (Figure 13; WP 163). The culvert is a 4-ft concrete pipe (200 ft in length). The stream channel is ephemeral at this point in the watershed, originating in a forested swale on the upstream side of the railroad grade. No water was flowing in the culvert or the downstream channel at the time of the survey. No fish were observed in the stream, and the channel is listed as a Type 9 by WA-DNR; therefore, the stream above the culvert was classified as non-fish bearing. The culvert size is adequate for flow conditions at this position in the watershed.

\section{$\underline{\text { RR MP } 17.96}$}

This RR culvert is located on a headwater tributary of Sherwood Creek (no assigned WRIA number) northwest of Allyn (Figure 13; WP 164). The culvert is a 5-ft concrete pipe (205 ft in length). The stream channel is ephemeral at this point in the watershed, originating in a forested swale on the upstream side of the railroad grade. No water was flowing in the culvert or the downstream channel at the time of the survey. No fish were observed in the stream, and the channel is listed as a Type 9 by WA-DNR; therefore, the stream above the culvert was classified as non-fish bearing. The culvert size is adequate for flow conditions at this position in the watershed. 


\section{$\underline{\text { RR MP 21.67 (Figures } 35 \text { and 36) }}$}

This RR culvert is located in the headwaters of Lake Devereaux Creek (WRIA 14.0125) between Allyn and Belfair (Figure 13; WP 159). The culvert is a 3-ft concrete pipe (132 ft in length). The culvert is classified as a fish passage barrier based on WDFW Level-B analysis. The culvert is undersized and there isa small ( $\sim 6 \mathrm{ft}$ ) water fall located just downstream of the culvert outlet. This barrier may have formed as a result of excessive flows through this culvert or may have been natural, however, its location at the culvert outlet exacerbates the fish passage problem at this culvert. The culvert has a PI score of 7.34 based on habitat assessment surveys. Lake Devereaux and the outlet wetlands provide good rearing habitat upstream of the culvert, although the creek is seasonal and very dependent on flows from the lake. There is adequate spawning and rearing habitat located downstream; however, there are at least two other barrier culverts downstream of the railroad culvert. The most significant of these barriers is at the mouth of the creek (SR-104), which should be replaced by the Washington State Department of Transportation (WSDOT) so as to allow full access to the stream system for native salmonids.

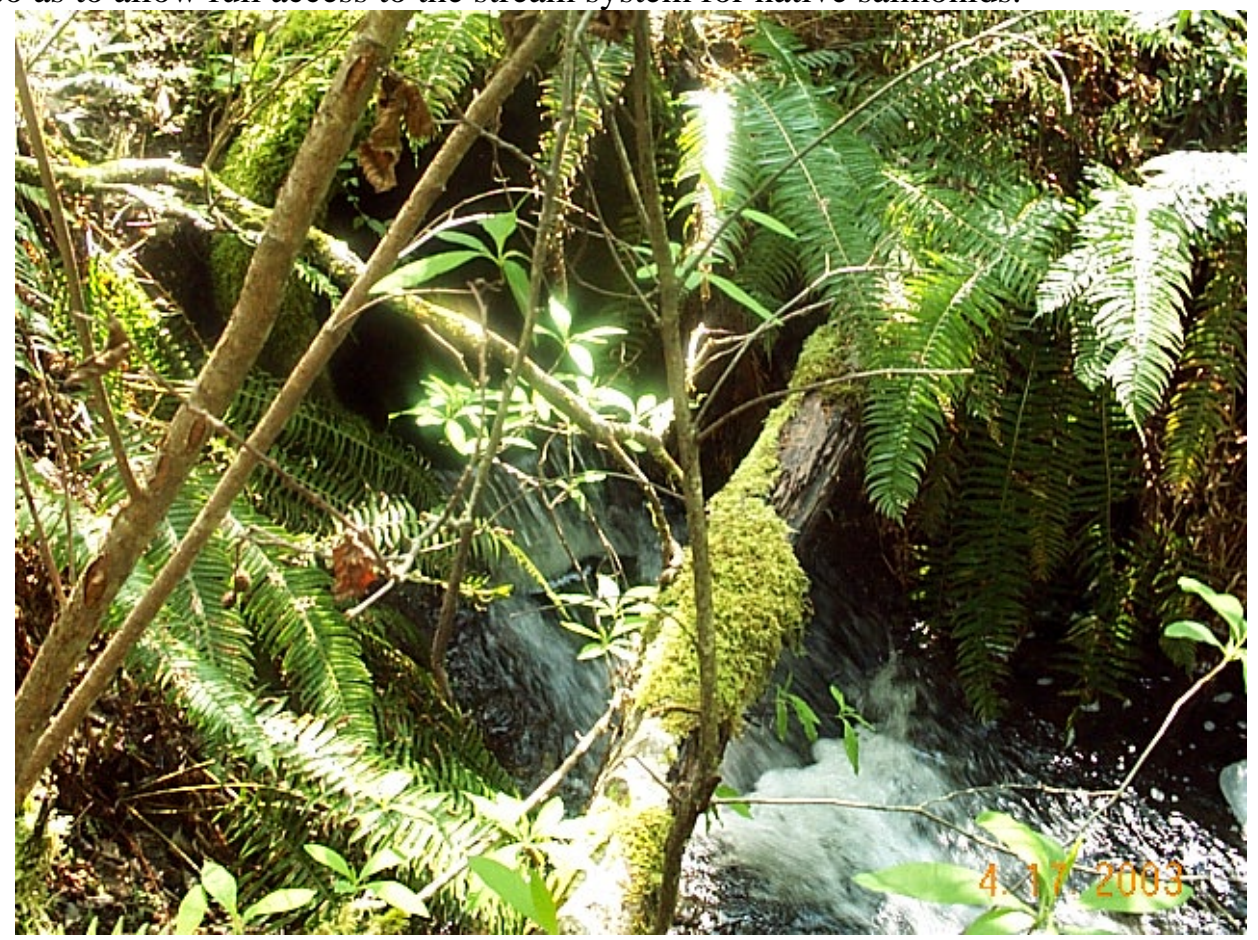

Figure 35. Outlet of railroad culvert MP 21.67. 


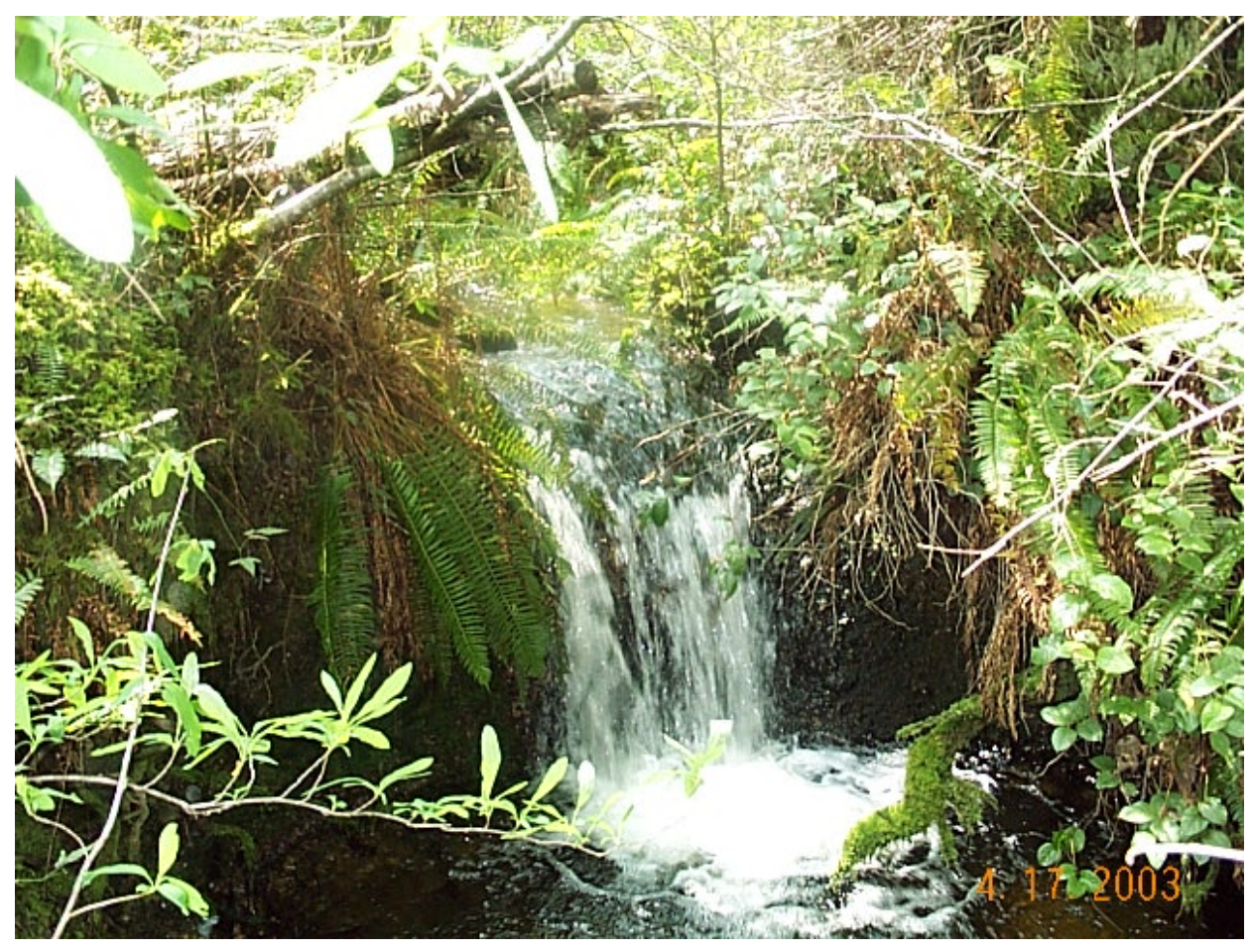

Figure 36. Falls just downstream of outlet of railroad culvert MP 21.67. 
RR MP 28.24 (Figures 37, 38, and 39)

This RR culvert is located on the "Airport” tributary of the Union River (WRIA 15.0512) between Belfair and Gorst (Figure 14; WP 153). The culvert is a 4-ft concrete pipe (278 ft in length). The stream was classified as fish-bearing by LFA (WCC, 2001). The culvert is classified as a complete barrier based on WDFW Level-A analysis (the culvert is undersized for the stream channel, the culvert gradient is $>1 \%$, no natural streambed material exists in the culvert, and the culvert outlet is perched 3 feet above the streambed). These findings are from a report by WDFW personnel who conducted culvert assessment and instream habitat assessment surveys in 2001. The culvert has a PI score of 15.32 (WDFW, 2001). In addition to being a passage barrier, recent inspections by Navy railroad engineers found that there are structural defects in the culvert, such that the culvert will need to be replaced in the next 5 to 10 years. This culvert replacement has been placed on the long-range maintenance schedule for the Navy railroad. Because of the size of the stream, the depth of railroad-grade fill, and length of this culvert, it is likely that a new culvert would have to be "bored and jacked" in place to correct this fish-passage barrier.

Stormwater runoff from the Bremerton Airport (City of Bremerton and Kitsap County jurisdiction) has also resulted in significant stormwater flow increases in the upstream channel, as well as streambank erosion and streambed scour. The result has been significant degradation in spawning and rearing habitat upstream of the railroad culvert and an exacerbation of the flow-capacity problems of the original culvert design (WDFW, 2001). The correction of this stormwater runoff problem should be integrated with any long-term plan for culvert replacement. In addition, rehabilitation of damaged or lost habitat between the railroad grade and the airport will also be required. Although this stream is classified as perennial by WDFW, flow is very seasonal and is dependent on the headwater wetlands located on airport property for flow. There are water quality concerns with these wetlands, as they receive runoff from the airport runway and hanger areas. Coordination between WDFW, City of Bremerton, Kitsap County, HCSEG, and the Navy will be required to correct this fish passage barrier, as well as the stormwater problems and instream habitat rehabilitation needs. 

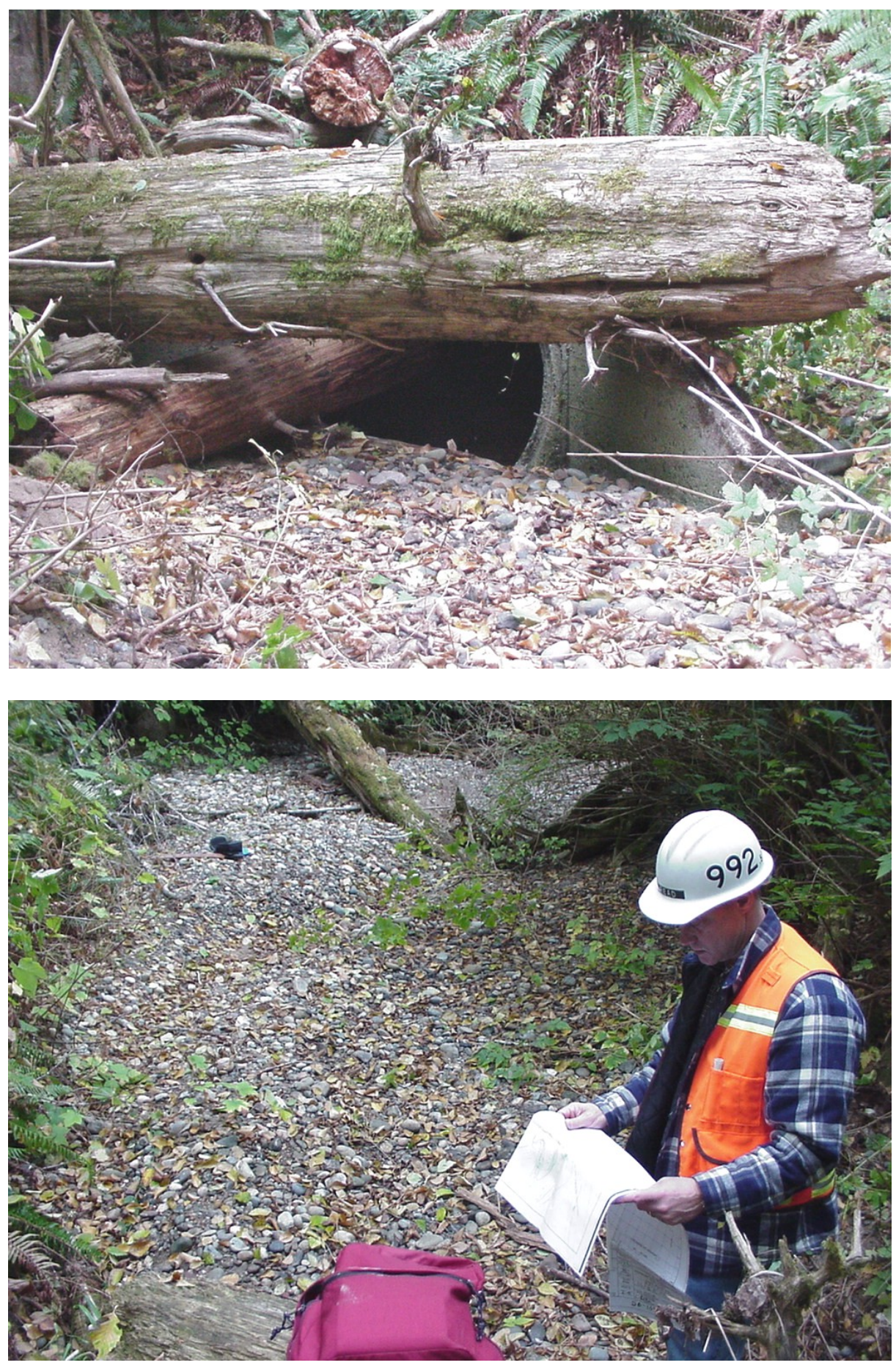

Figure 37. Inlet of railroad culvert MP 28.24. 


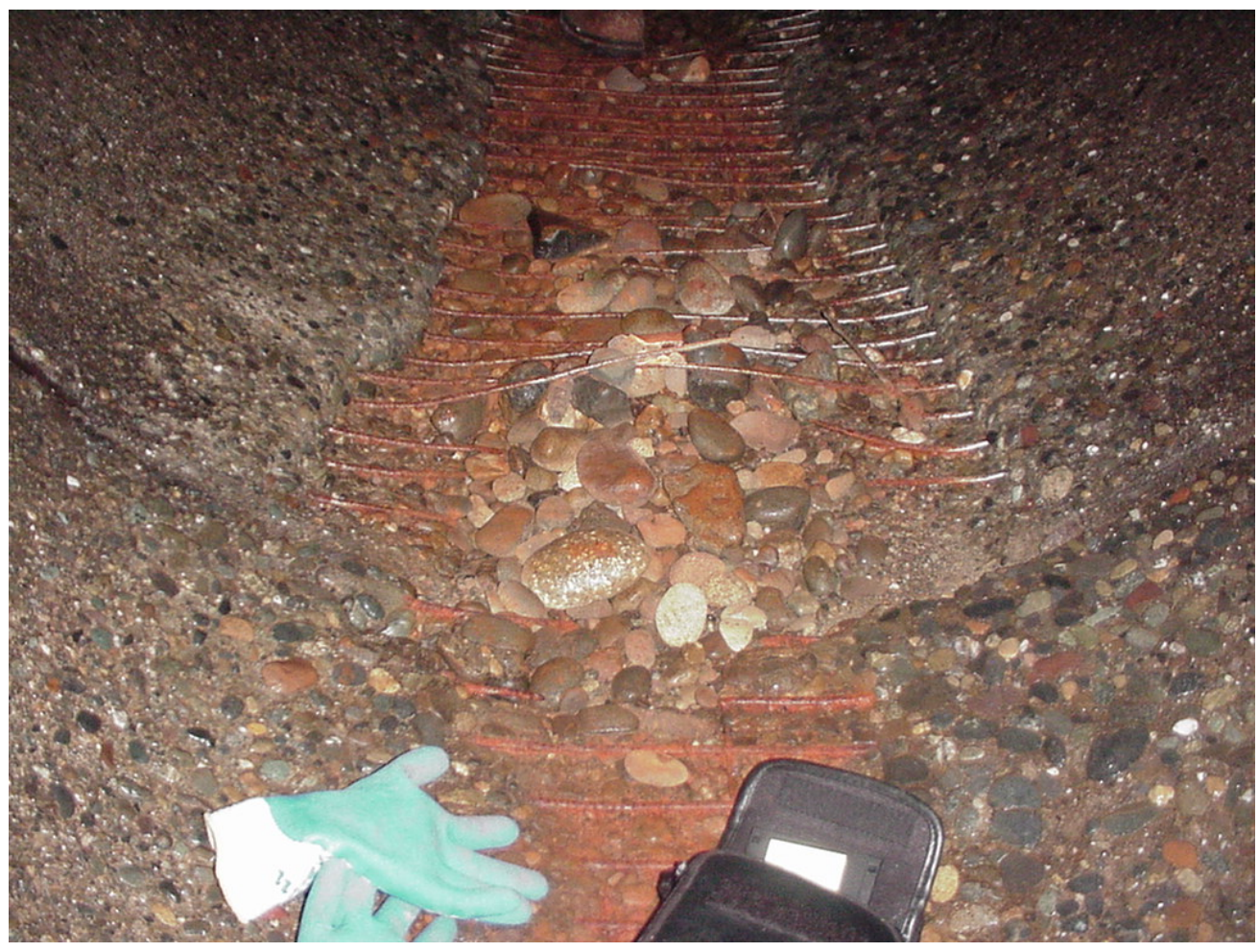

Figure 38. Interior structural damage to railroad culvert MP 28.24.

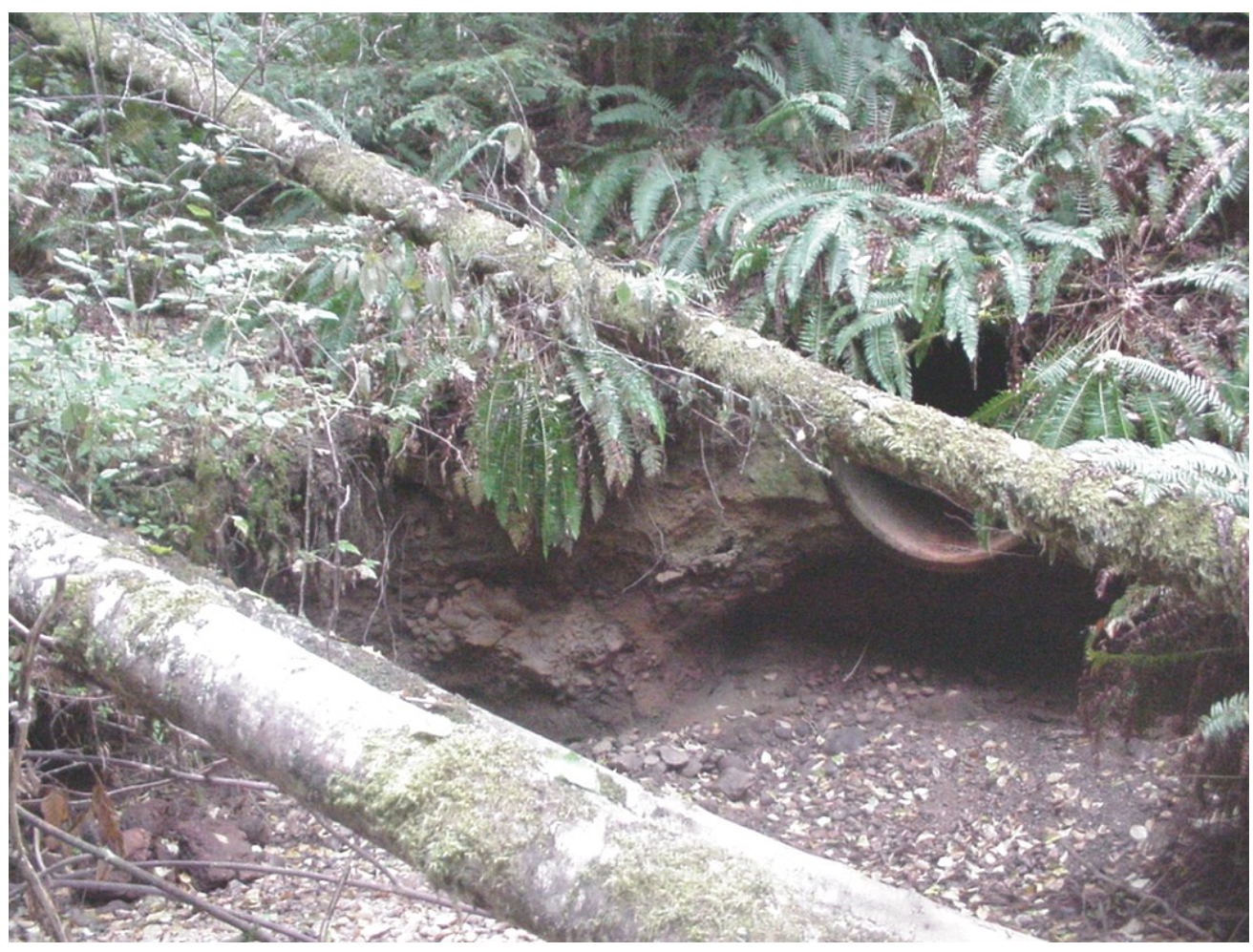

Figure 39. Outlet of railroad culvert MP 28.24. 


\section{$\underline{\text { RR MP 28.48 }}$}

This RR culvert is located on a headwater tributary of the Union River (WRIA 15.0514) between Belfair and Gorst (Figure 14; WP 154). The culvert is a 4-ft concrete pipe (57 ft in length). The culvert is classified as passable based on WDFW Level-A analysis.

\section{$\underline{\text { RR MP } 30.87}$}

This culvert is located at the headwaters of a tributary of Gorst Creek (no assigned WRIA number) northwest of Gorst (Figure 14; WP 155). The culvert is a 3-ft concrete pipe (133 ft in length). The stream channel is ephemeral at this point in the watershed, originating in a forested swale on the upstream side of the railroad grade. However, the stream is classified as potentially fish-bearing based on reports from Suquamish tribal biologists that coho have been observed spawning just downstream of the culvert during multiple survey years. The Suquamish tribal biologist (Jon Oleyar) reports that the stream only has surface flows during storm events and is hyporheic for the remainder of the year, but may be usable by salmonids during some flow conditions. The culvert is classified as passable based on WDFW Level-A analysis. 


\section{$\underline{\text { RR MP } 31.55}$ (Figures 40 and 41)}

This RR culvert is located on a tributary of Gorst Creek (WRIA 15.0223) northwest of Gorst (Figure 14; WP 161). The culvert is an 8- by 5 -ft concrete box culvert (180 ft in length) that has been classified as passable by WDFW Level-A analysis. There is adequate flow capacity in the culvert as sized, the culvert gradient is $<1 \%$, and natural streambed material exists throughout. However, there is a debris jam located just downstream of the culvert that may be causing a partial barrier at the culvert inlet during high flow conditions. The Suqumish Tribe and WDFW habitat biologists have recommended that this debris jam be relocated downstream (WDFW Hydraulic Permit required) and the creek monitored. One section of the culvert roof may also be cracked. Although not believed to be a structural or passage problem, it should be investigated by railroad engineers. These corrective actions have been scheduled. There is ample, good quality spawning and rearing habitat upstream and downstream of the culvert. Juvenile salmonids were observed upstream and downstream of the culvert during stream surveys. In addition, the Suquamish Tribe spawning surveys have noted that this is a very productive tributary in the Gorst Creek system.

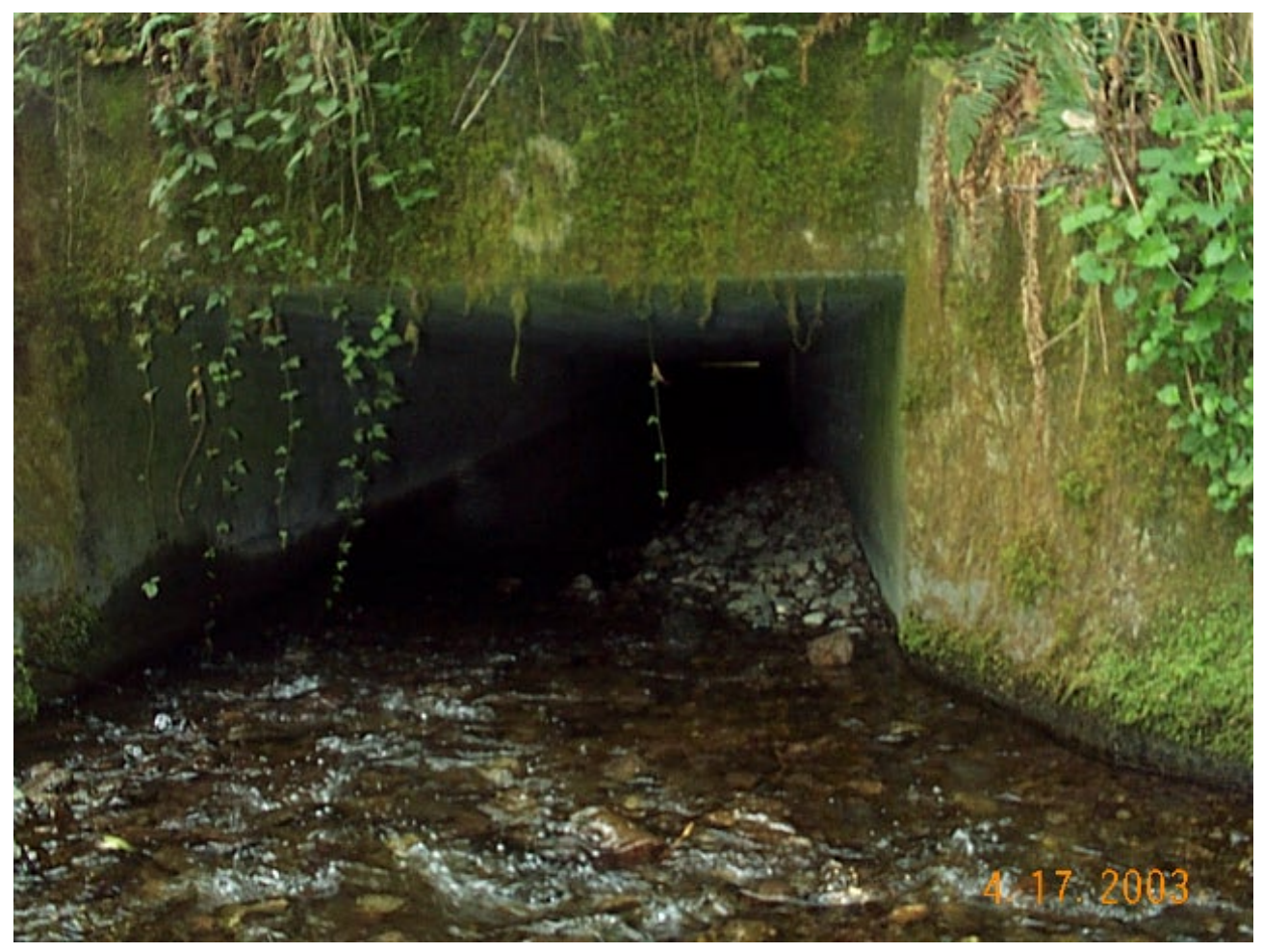

Figure 40. Inlet of railroad culvert MP 31.55. 


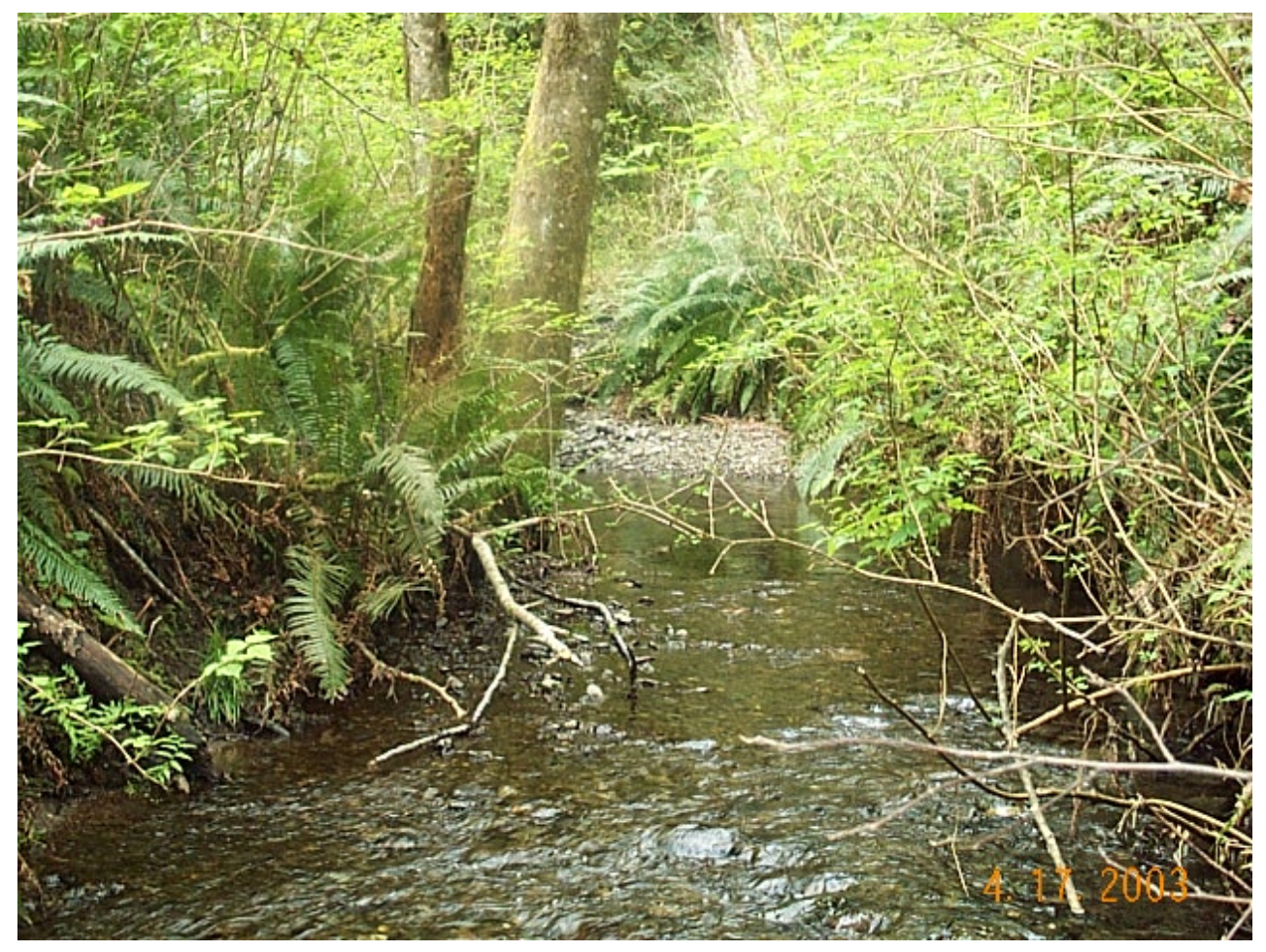

Figure 41. Instream habitat upstream of railroad culvert MP 31.55. 
RR MP 32.09 (Figures 42, 43, and 44)

This RR culvert is located at the headwaters of an un-named tributary of Gorst Creek northwest of Gorst (Figure 14; WP 156). The culvert is a 30-in. concrete pipe (213 ft in length). The stream channel is seasonal at this point in the watershed, originating in a steep ( $>20 \%$ slope) forested area on the upstream side of the railroad grade. No water was flowing in the culvert or the downstream channel at the time of the survey, although there was flow upstream of the culvert, so the creek is likely hyporheic for much of the year throughout sections of this tributary. The culvert was assessed as a fish-passage barrier based on WDFW Level-B analysis. An instream habitat assessment was conducted and a PI score of 2.17 was determined. Upstream habitat is limited mainly by the steep gradient. No fish were observed in the stream, however limited resident salmonid use may be possible just upstream of the culvert based on channel size and habitat conditions. In addition, limited juvenile rearing habitat also exists. Therefore, the stream is classified as potentially fish-bearing. There were several potential barriers noted downstream of the culvert (beaver dams and logging road culverts on City of Bremerton property). These culverts should be evaluated and PI scores derived for each.

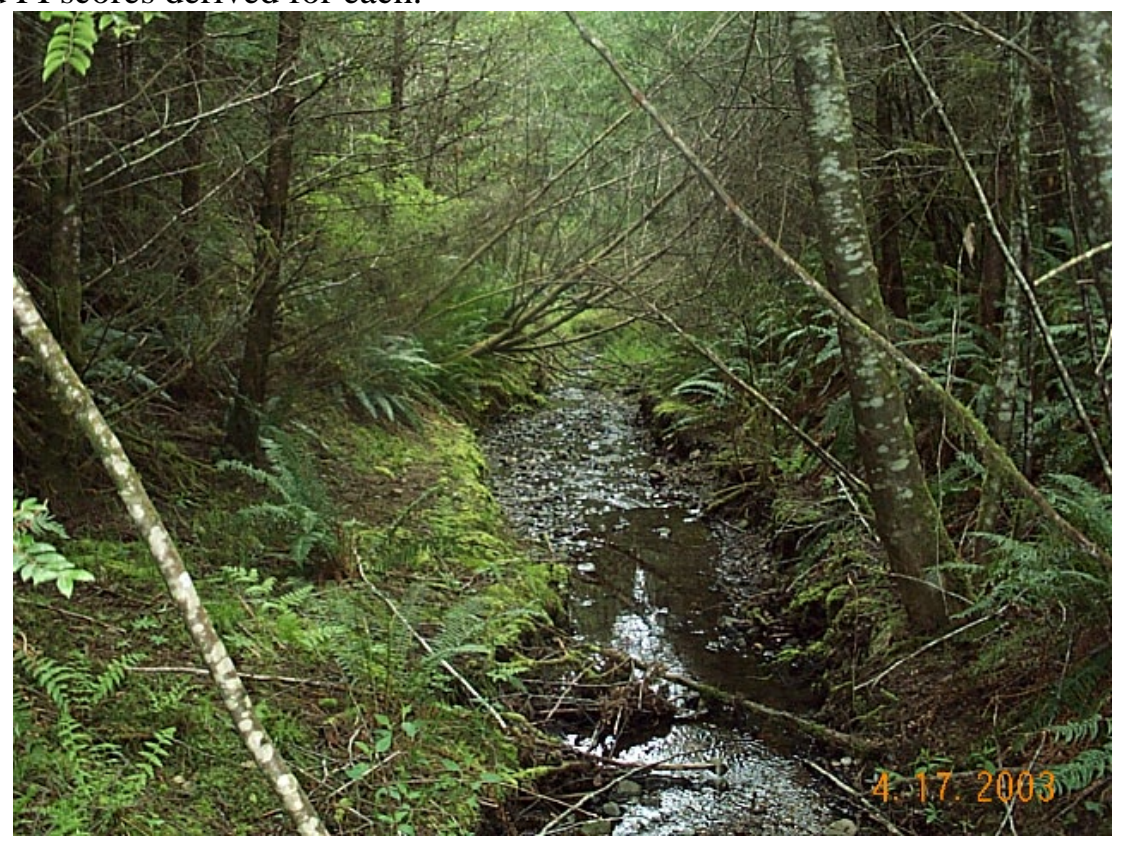

Figure 42. Instream habitat downstream of railroad culvert MP 32.09. 

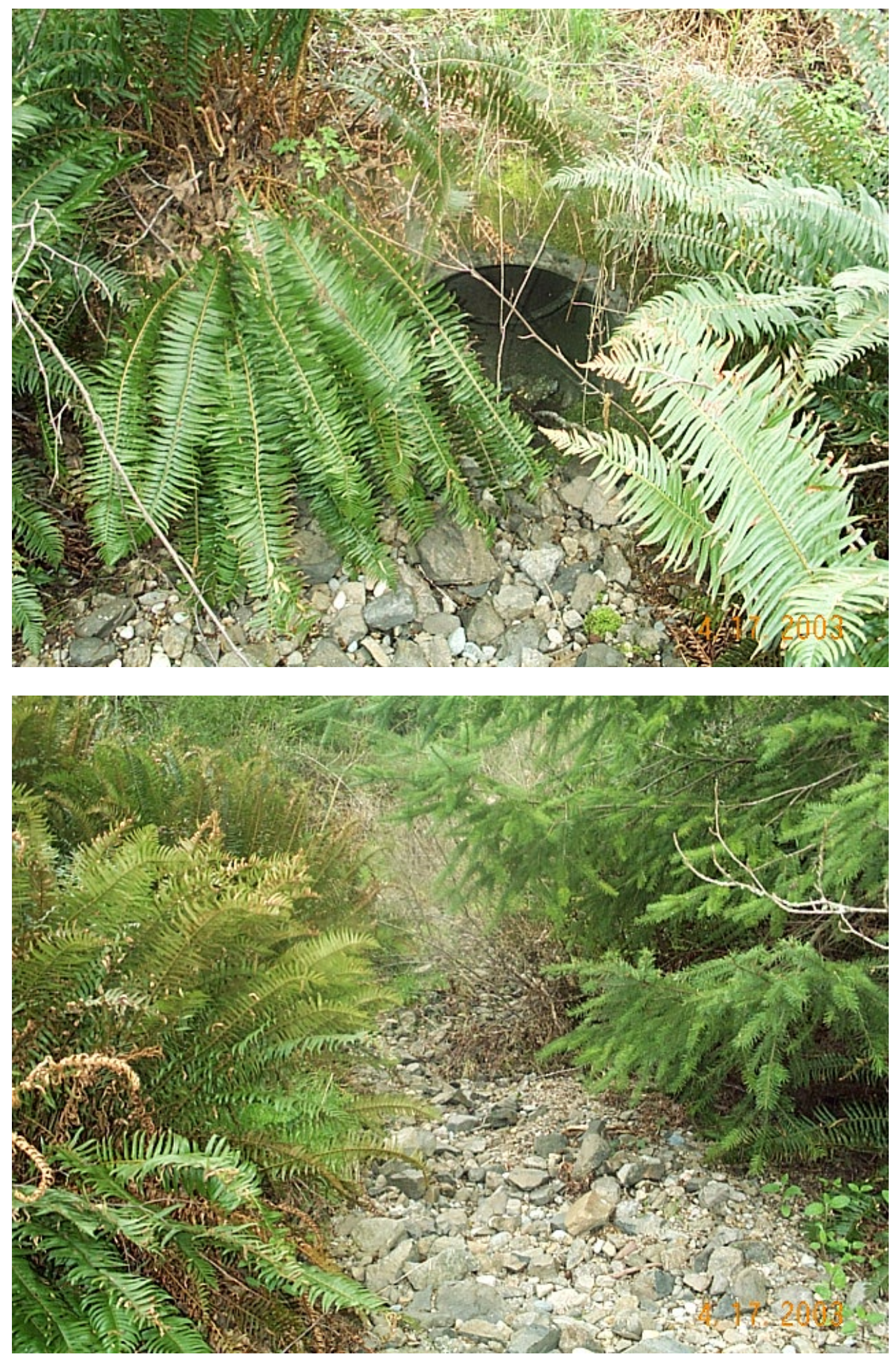

Figure 43. Outlet of railroad culvert MP 32.09. 

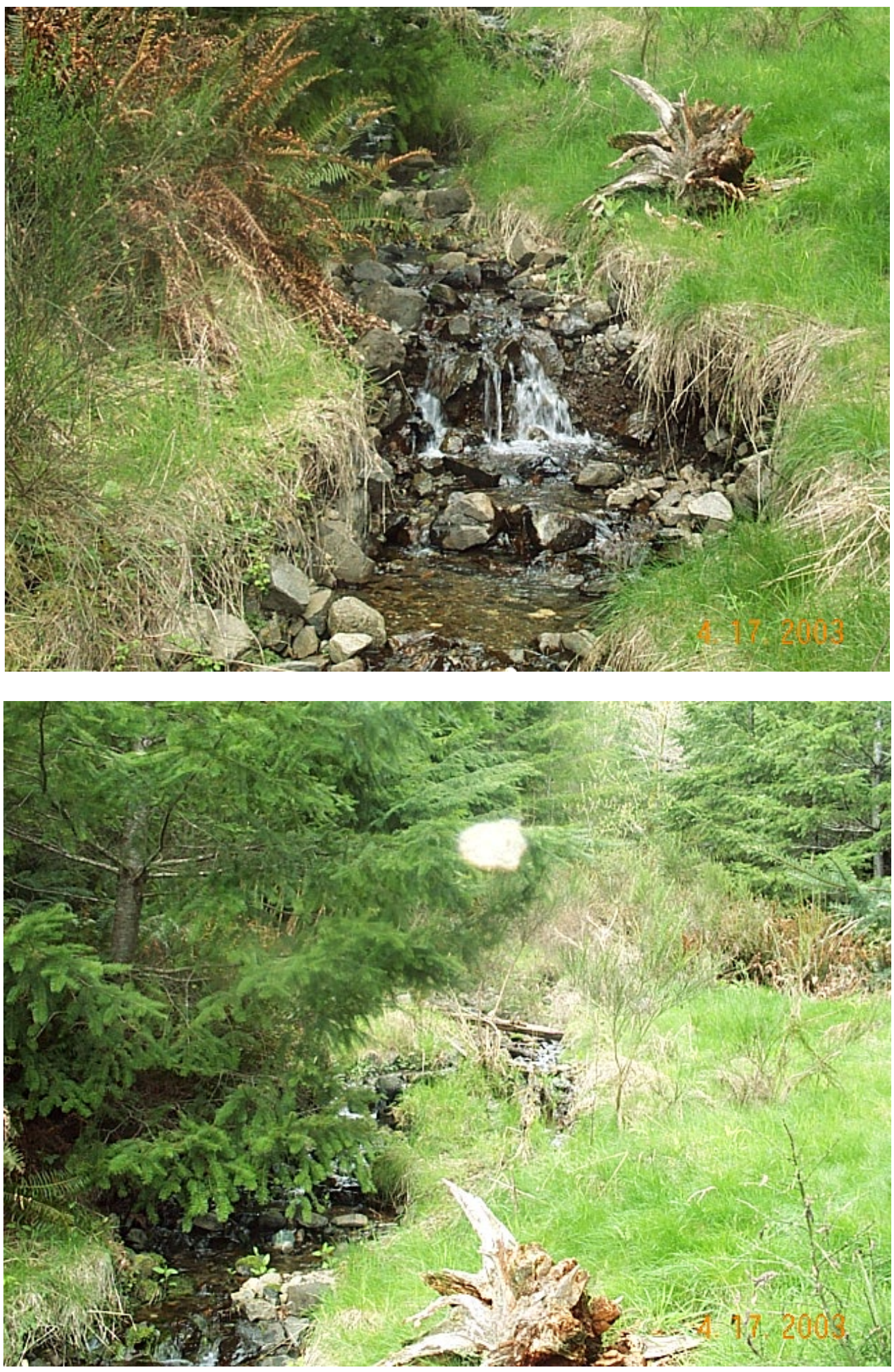

Figure 44. Instream habitat just upstream of railroad culvert MP 32.09. 


\section{$\underline{\text { RR MP 0.71 (Figure 45) }}$}

This RR culvert is located on the Heins Creek tributary of Gorst Creek (WRIA 15.0221) northwest of Gorst (Figure 14; WP 157). The culvert is an 8- by 5-ft concrete box culvert (159 ft in length) that has been classified as a barrier by WDFW Level-A analysis (survey conducted by WDFW in 2002). Juvenile and adult salmonids have been observed upstream and downstream of the culvert, so it is likely passable during certain flow conditions. There is ample, good quality spawning and rearing habitat upstream and downstream of the culvert. The culvert has a PI score of 9.79 (based on WDFW surveys conducted in 2002). There is also a downstream (partial) barrier on the City of Bremerton access road that should be corrected by the City in coordination with work on the RR culvert. Current plans call for the replacement of this downstream barrier and the installation of an engineered fishway on the railroad culvert during the summer of 2004. The use of grade-control weirs instead of a bridge or new culvert to correct this passage problem will likely necessitate some long-term maintenance, but should be sufficient to correct the barrier problem in the near-term.

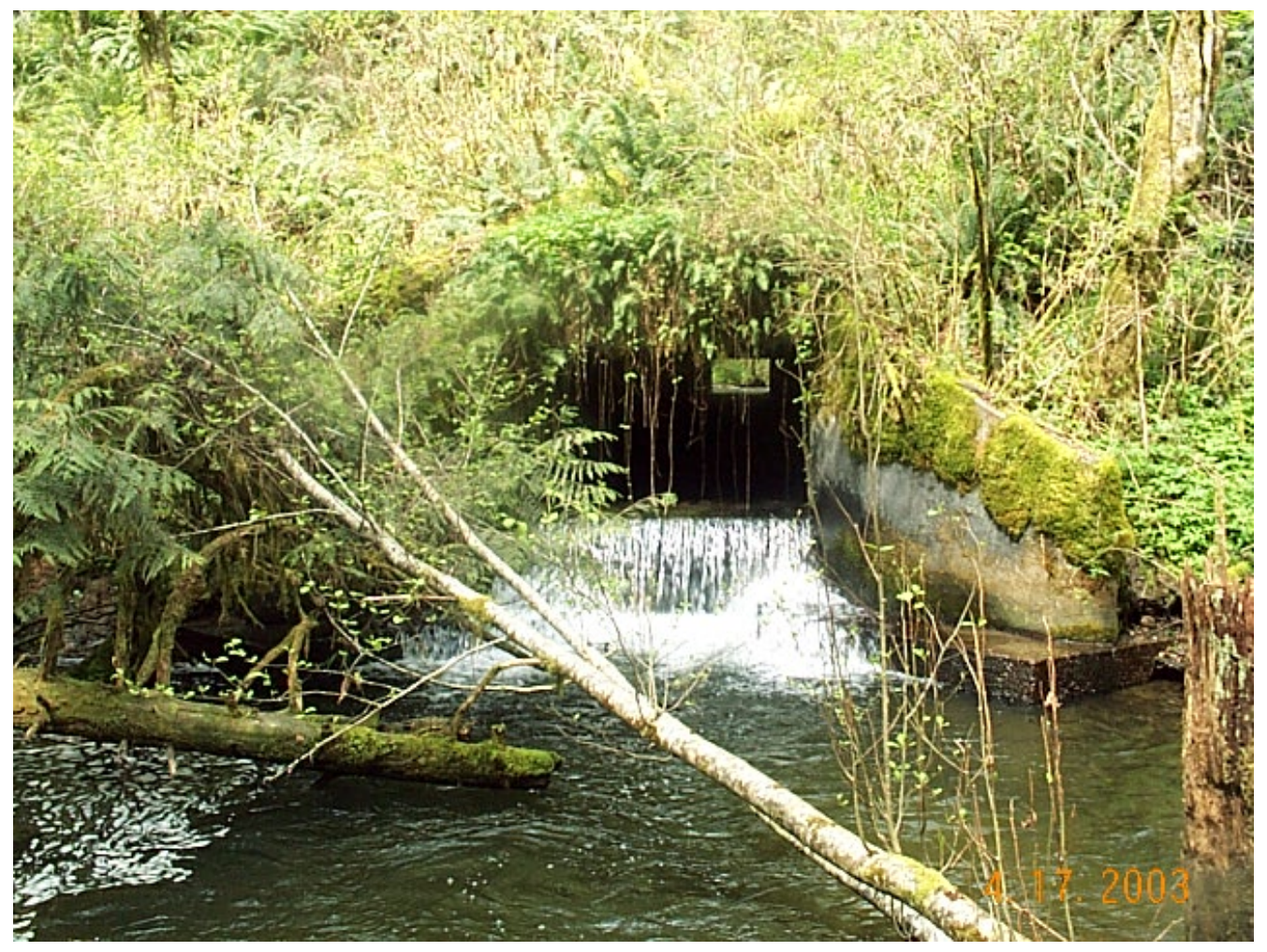

Figure 45. Heins Creek (railroad MP 0.71) culvert outlet. 
$\underline{\text { RR MP } 1.04}$ (Figures 46, 47, 48, 49, and 50)

This culvert is located on the Jarstad Creek tributary of Gorst Creek (WRIA 15.0218) northwest of Gorst (Figure 14; WP 158). The culvert is a 3 -ft concrete pipe with 30-in. corrugated-metal piping attached to each end (267 ft in length). The reason for this unusual configuration is unknown, but it has resulted in a complete barrier to fish passage. There is also a downstream (partial) barrier at the City of Bremerton access road that should be corrected by the City as soon as possible. This undersized, downstream culvert is a 2-ft concrete box, with no natural streambed material in the culvert. This culvert is likely a barrier to juveniles during all flows and possibly adults under low or high flow conditions. The railroad culvert was found to be a complete barrier to fish passage based on the standard WDFW culvert survey (Level-A analysis). There is ample, good quality spawning and rearing habitat upstream of the railroad culvert. The railroad culvert has a PI score of 10.17. This culvert should be replaced with a bottomless arched culvert or a box-culvert bridge. As with Heins creek, the downstream (partial) barrier should also be replaced by the City of Bremerton in coordination with any scheduled railroad culvert corrective action.

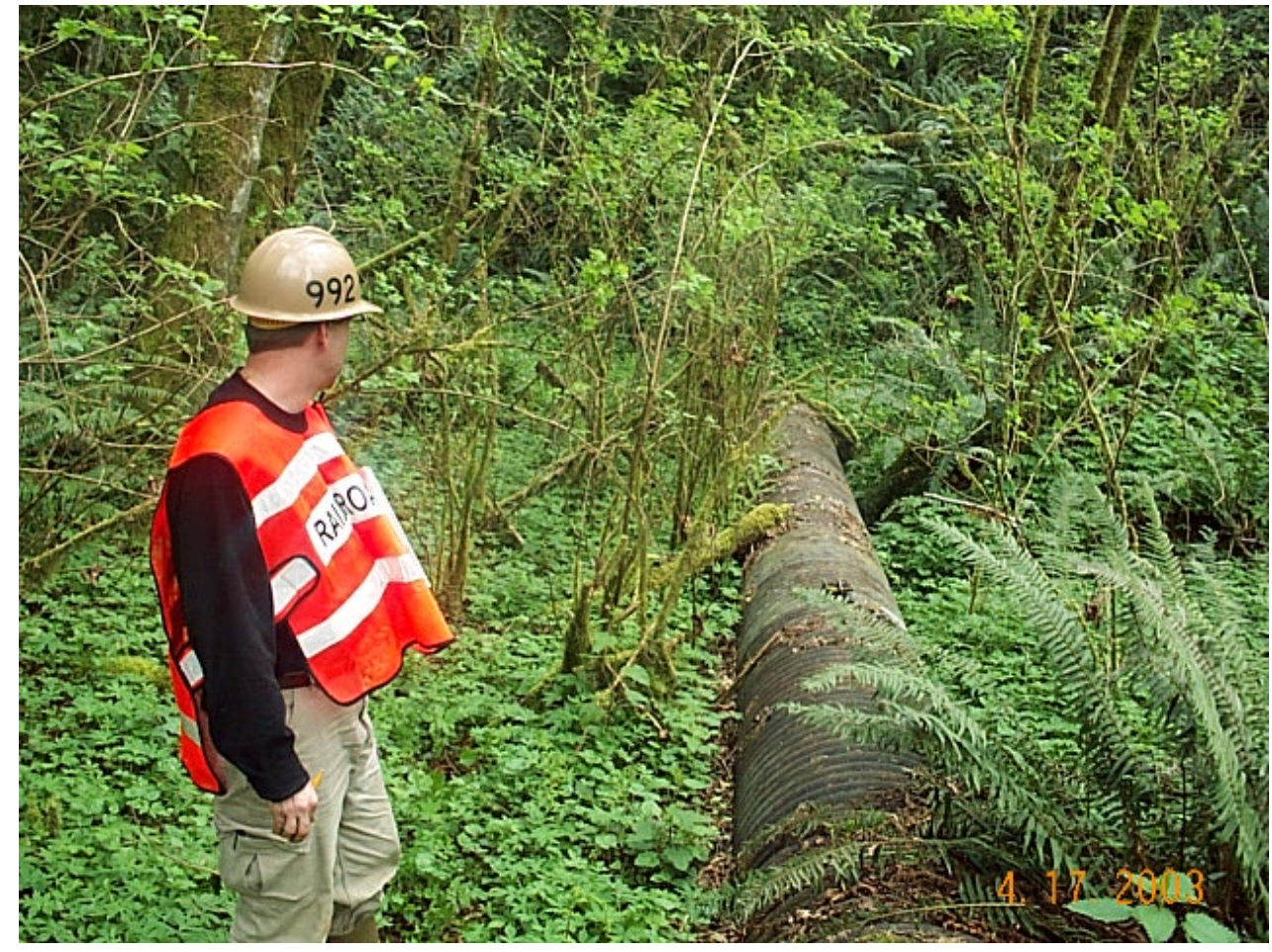

Figure 46. Upstream extension on Jarstad Creek (railroad MP 1.04) culvert. 

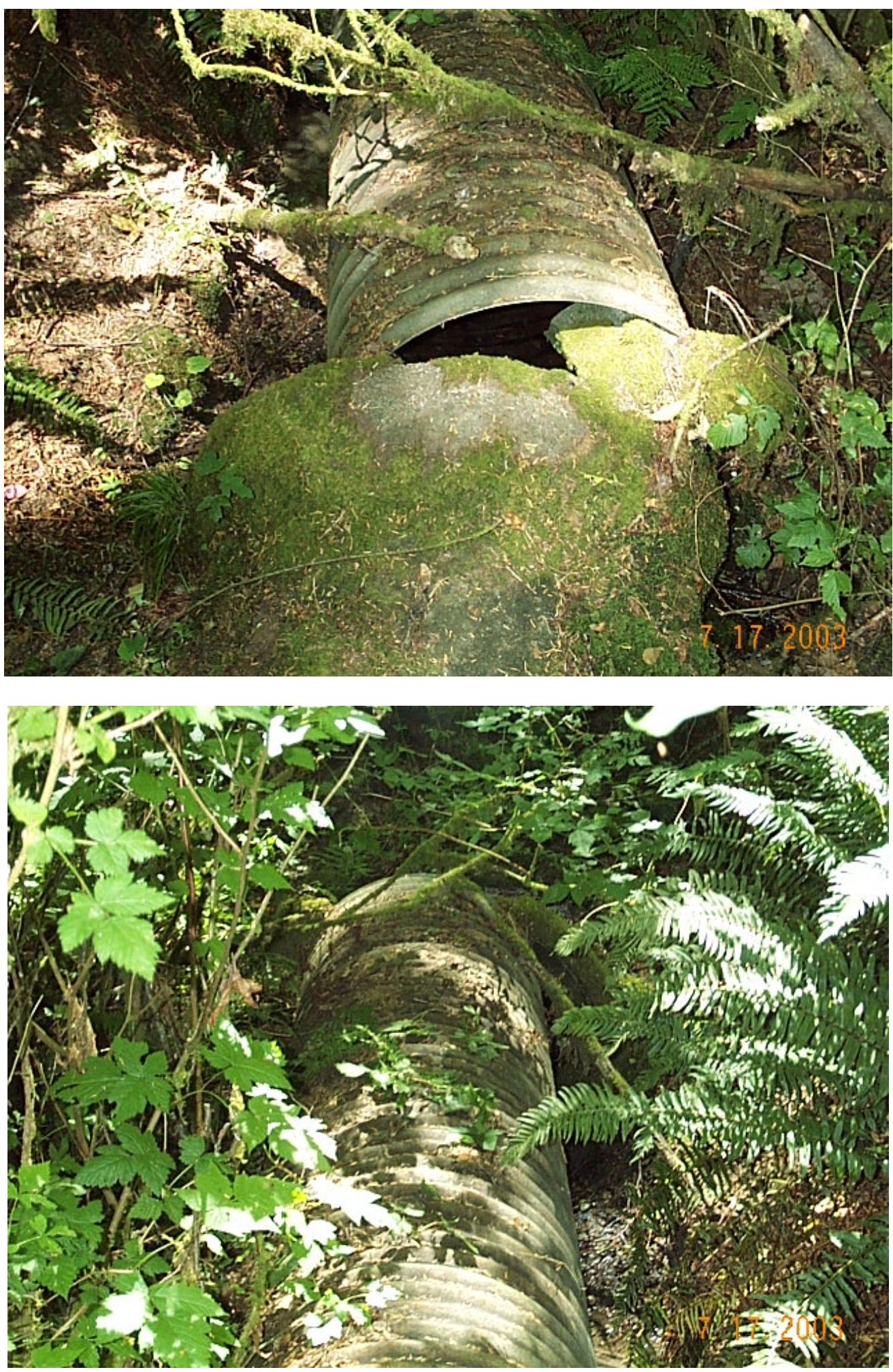

Figure 47. Upstream extension on Jarstad Creek (railroad MP 1.04) culvert. 

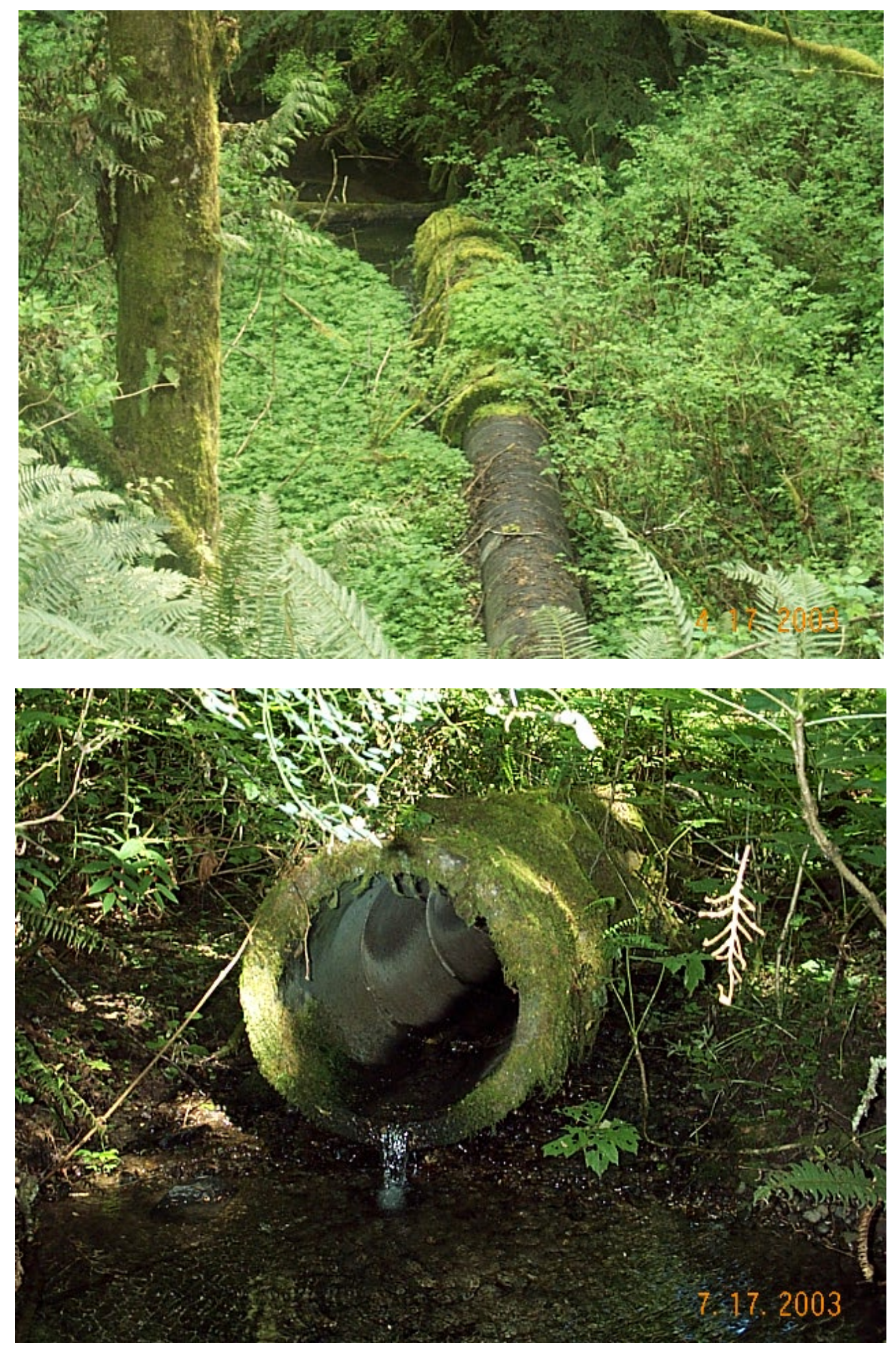

Figure 48. Outlet of Jarstad Creek (railroad MP 1.04) culvert. 


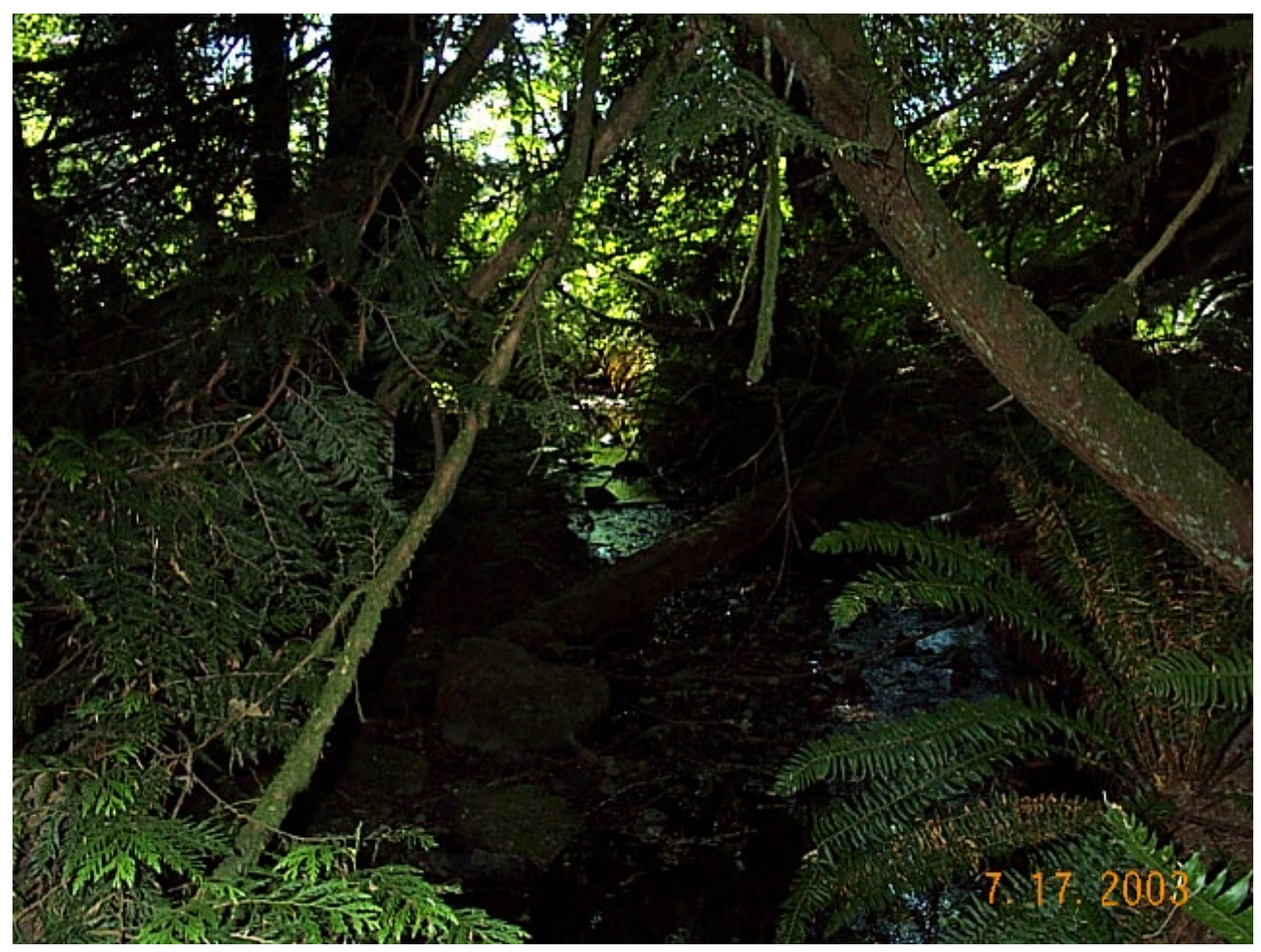

Figure 49. Instream habitat downstream of Jarstad Creek (railroad MP 1.04) culvert.

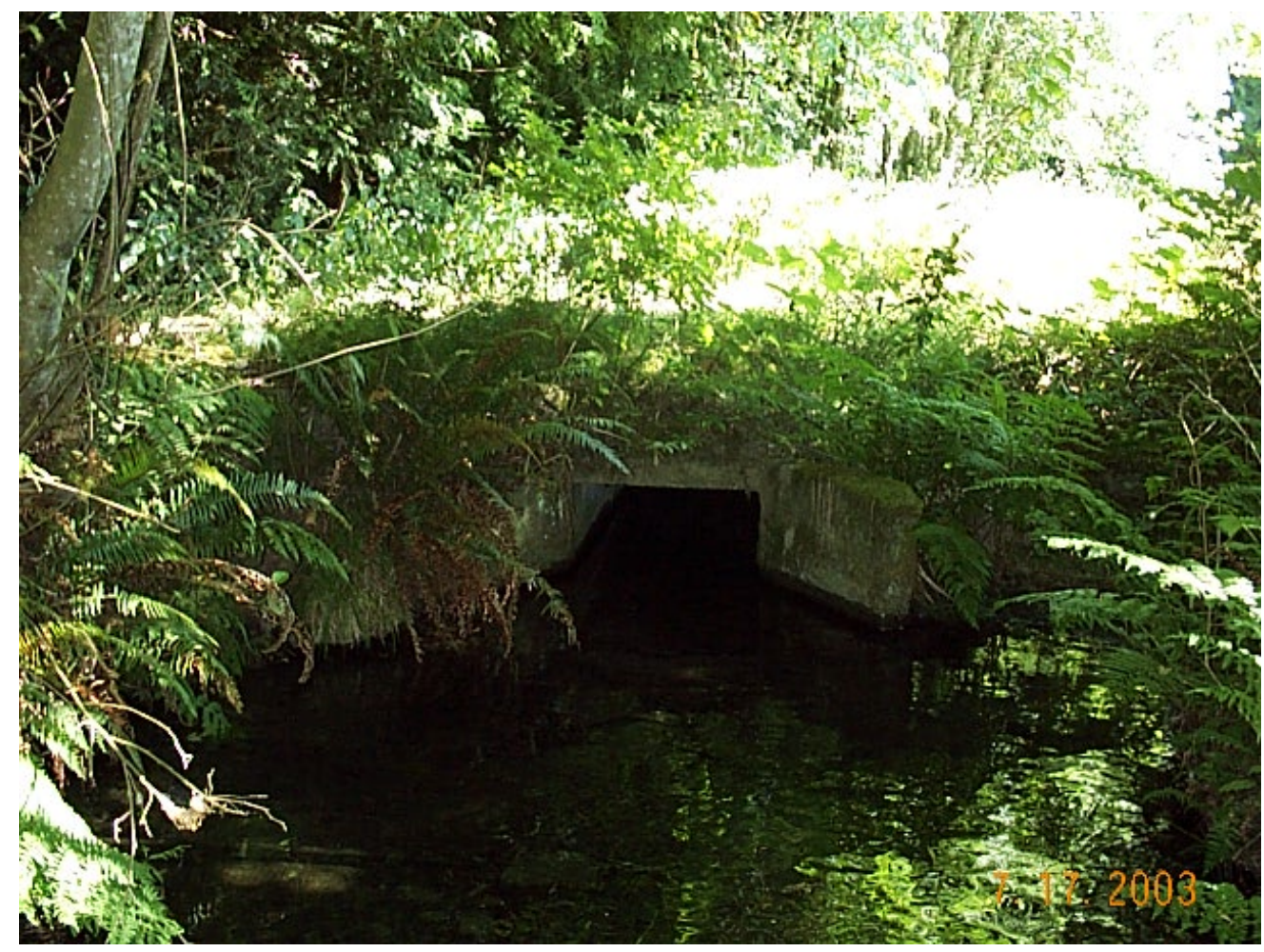

Figure 50. Bremerton culvert downstream of Jarstad Creek (railroad MP 1.04) culvert. 


\subsection{RECOMMENDATIONS}

The corrective action recommended for each culvert identified as a passage barrier will depend on the site-specific conditions. The general process of culvert-passage correction is illustrated in Figure 51. Details of this process can be found in the WDFW Fish Passage at Road Culverts Design Manual (WDFW 1999). Culverts should also be aligned with the active stream channel.In addition, construction of downstream hydraulic controls may also be required. These include holding or resting pools, gradecontrol or step-pool weirs, streambank erosion control, streambed scour control, and instream habitat complexity. In general, the following fish-passage structural designs should be considered in order of preference (see Figures 52 through 62):

- Bridge (ideally, no encroachment into the CMZ or floodplain)

- Streambed Simulation Culvert Design (bottomless box or embedded arch culvert that matches natural streambed conditions)

- Non-embedded Culvert (slope $<0.5 \%$ and minimum water depth 6”)

- $\quad$ Engineered Fishway

- Baffled Culvert.

Trash racks should not be used on culvert inlets that are designed for fish passage. Instead, "fish-friendly" devices like the "beaver deceiver" (Appendix B) are recommended. In areas where beaver are active, screening of the culvert outlet may be necessary to prevent beavers from plugging the outlet with debris and blocking fish passage.. To facilitate unrestricted fish passage, all RR-tie trash racks should be removed from the inlets of RR culverts.

In addition to proper culvert design and installation, a comprehensive inspection and maintenance program should be implemented to ensure the long-term operation of culverts on the Navy railroad. Culverts should be routinely inspected for structural integrity, as well as fish passage, especially those in areas of beaver activity or where debris clogging is a known or recurring problem.

Specific recommendations for each culvert evaluated during this studyare summarized in Table 6 for each culvert in order of priority. 


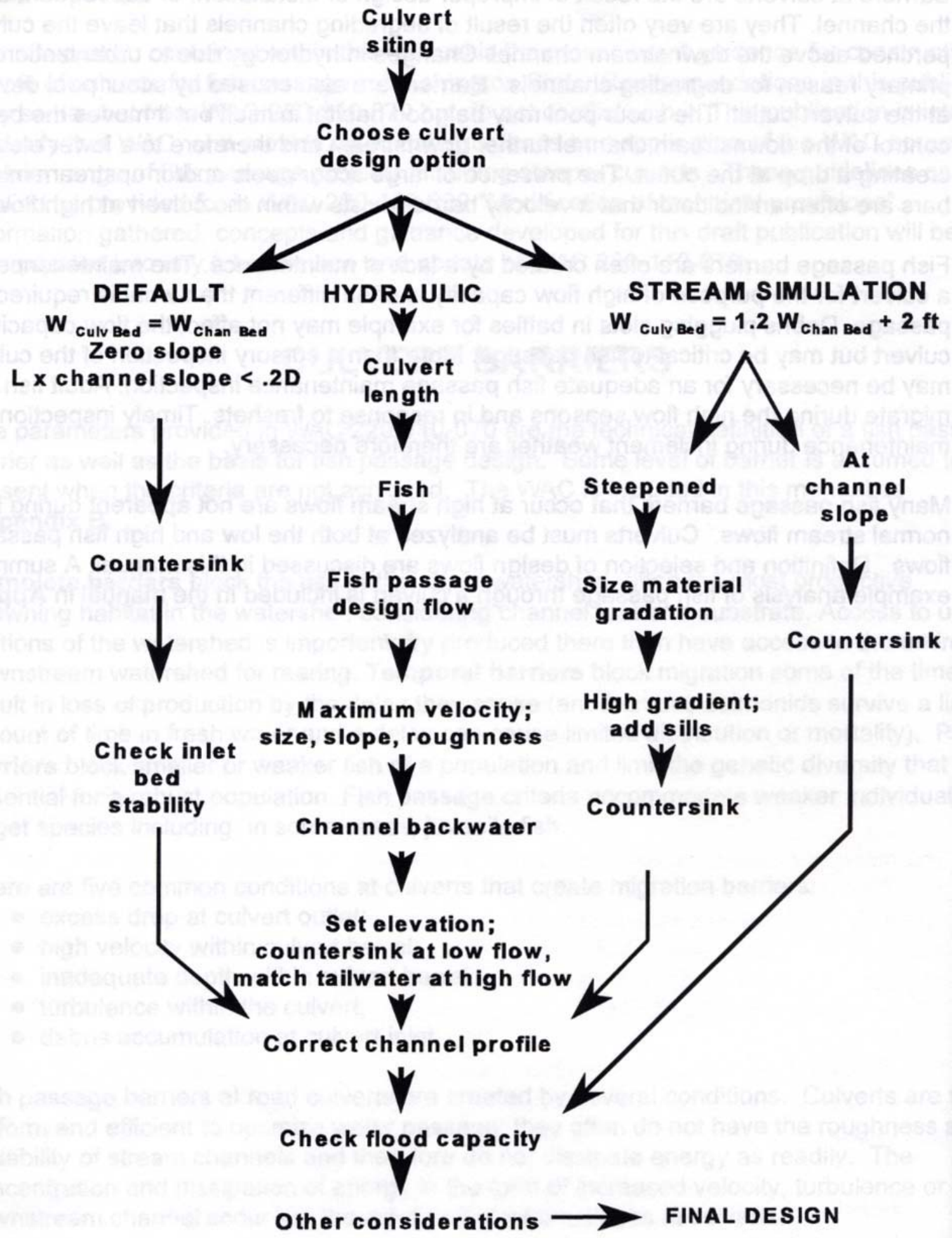

Figure 51. Culvert replacement flow diagram (WDFW 1999). 


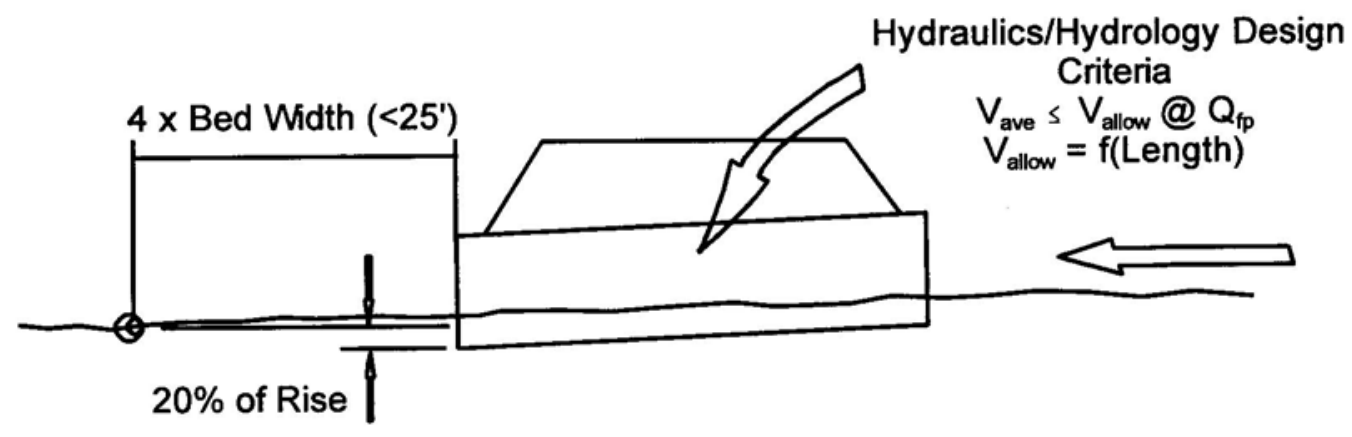

Figure 52. Culvert hydraulic-design option (WDFW 1999).

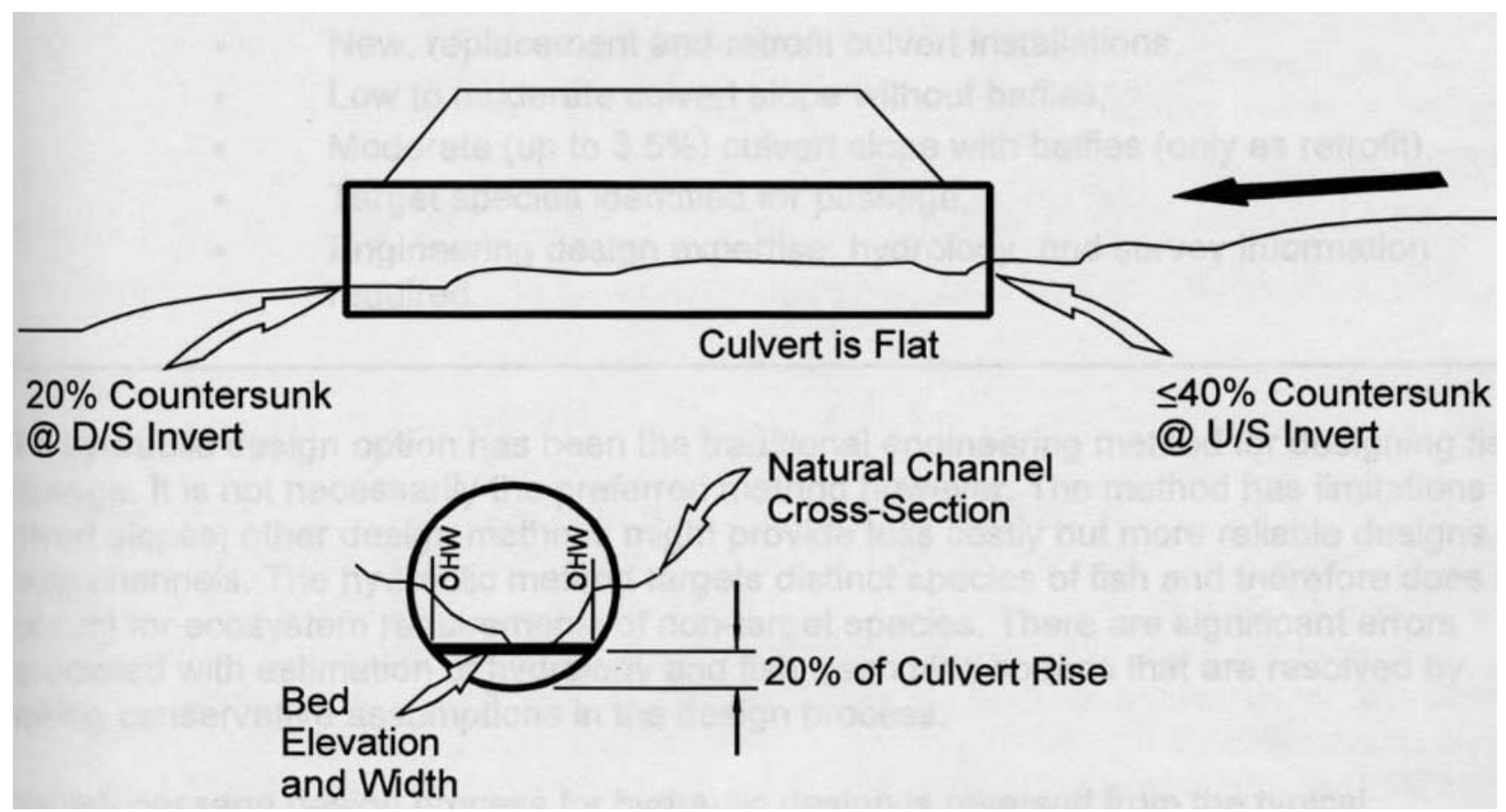

Figure 53. Culvert no-slope option (WDFW 1999). 


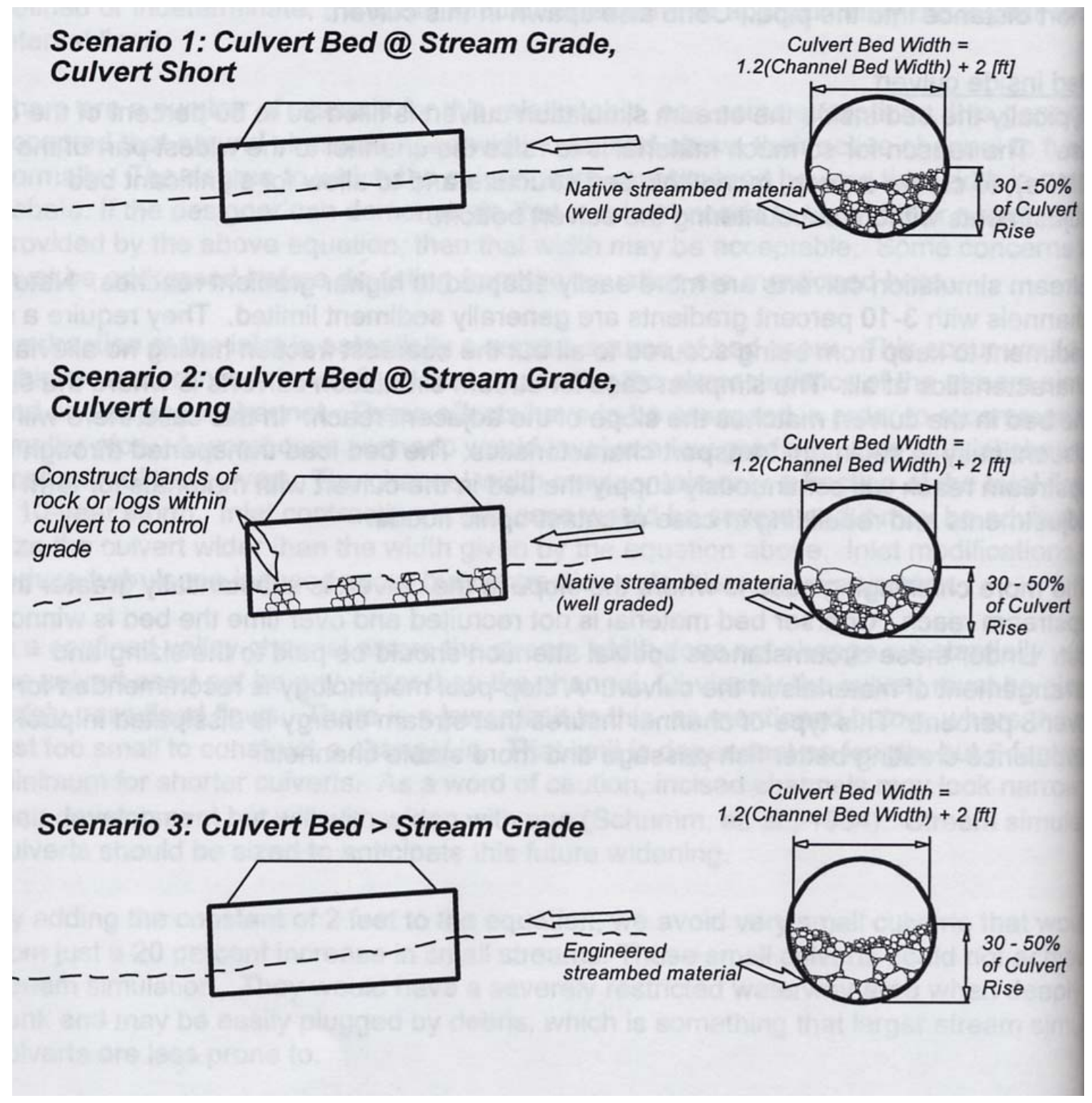

Figure 54. Culvert replacement options (WDFW 1999). 

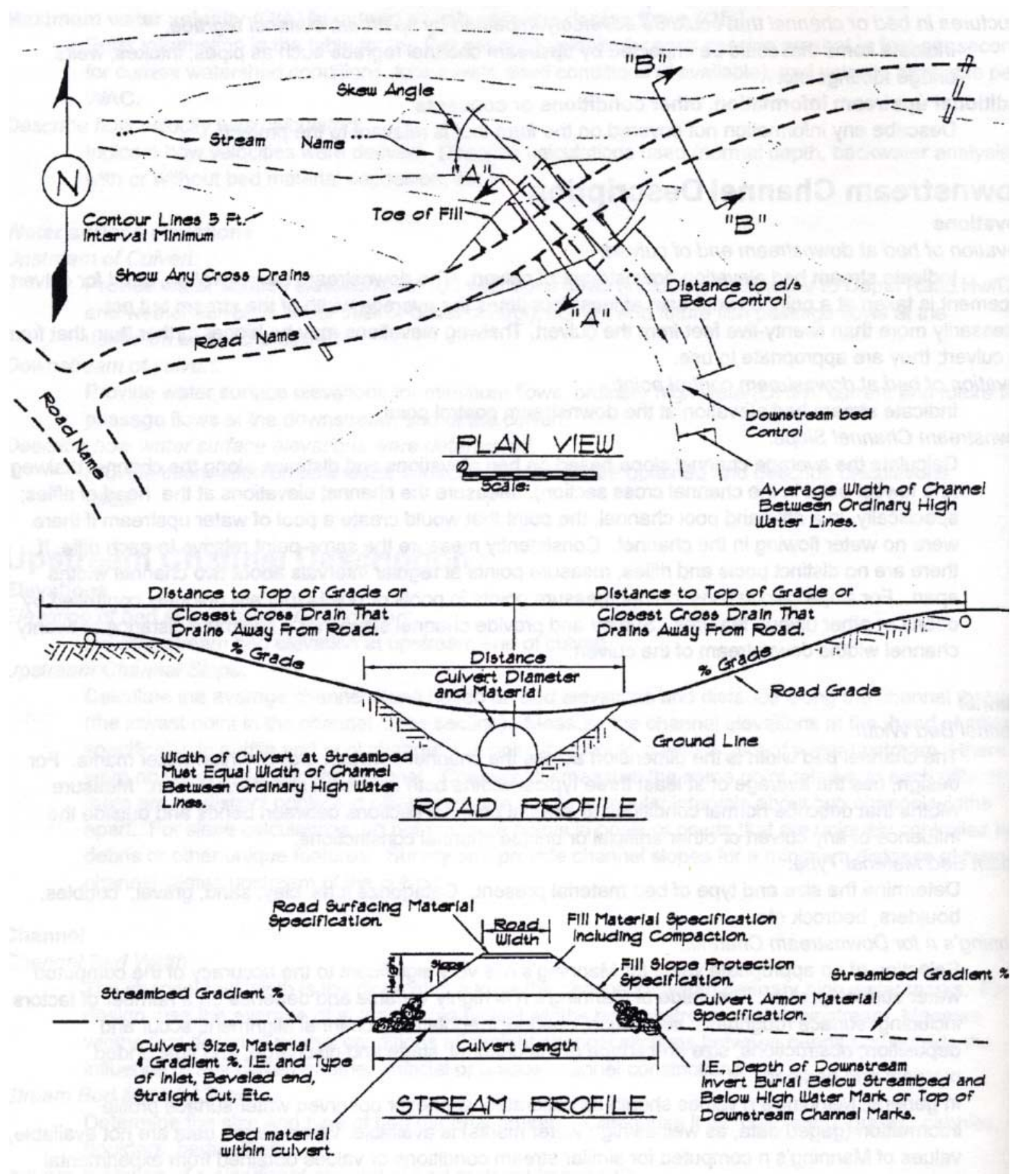

Figure 55. Culvert replacement options (WDFW 1999). 


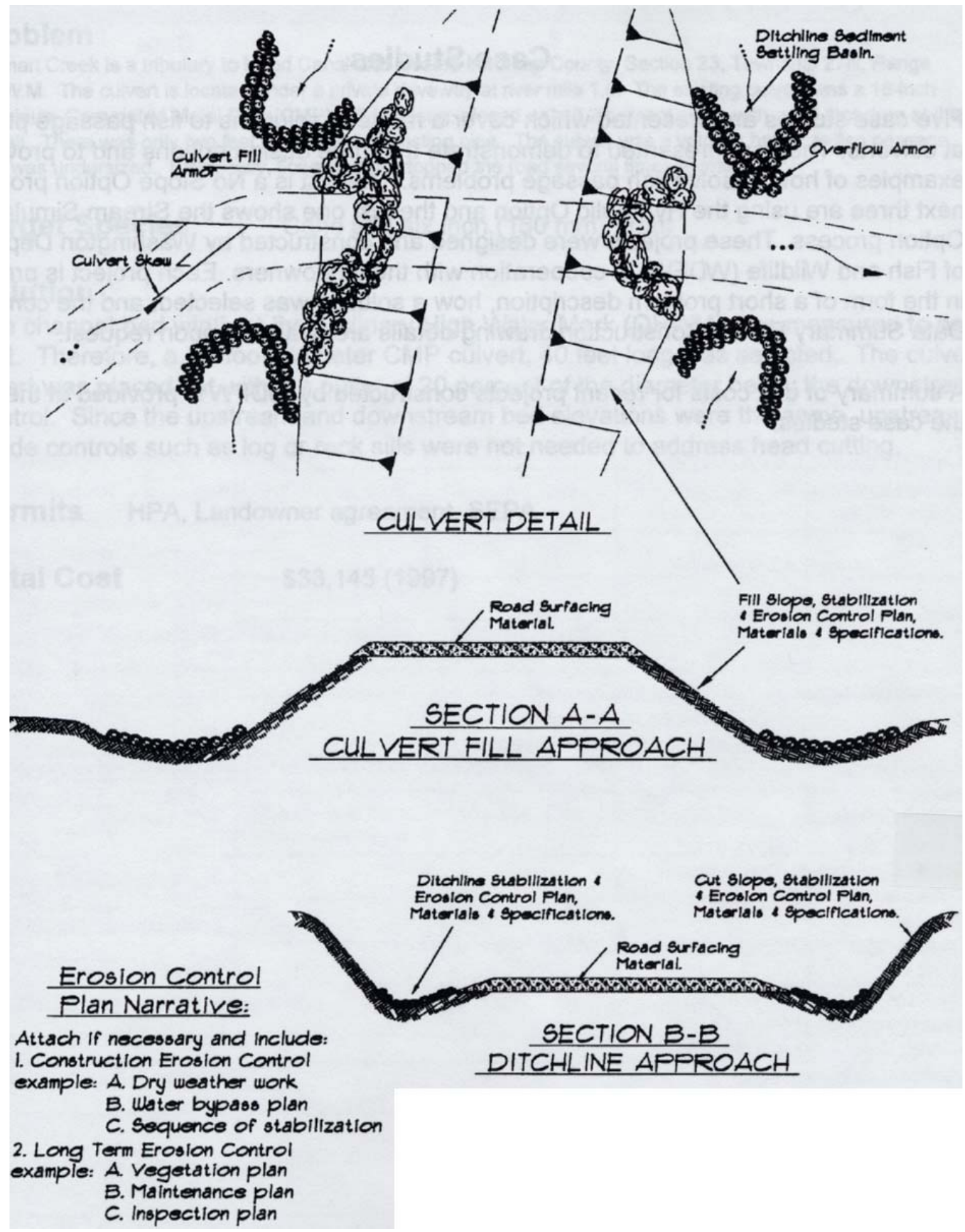

Figure 56. Culvert replacement options (WDFW 1999). 


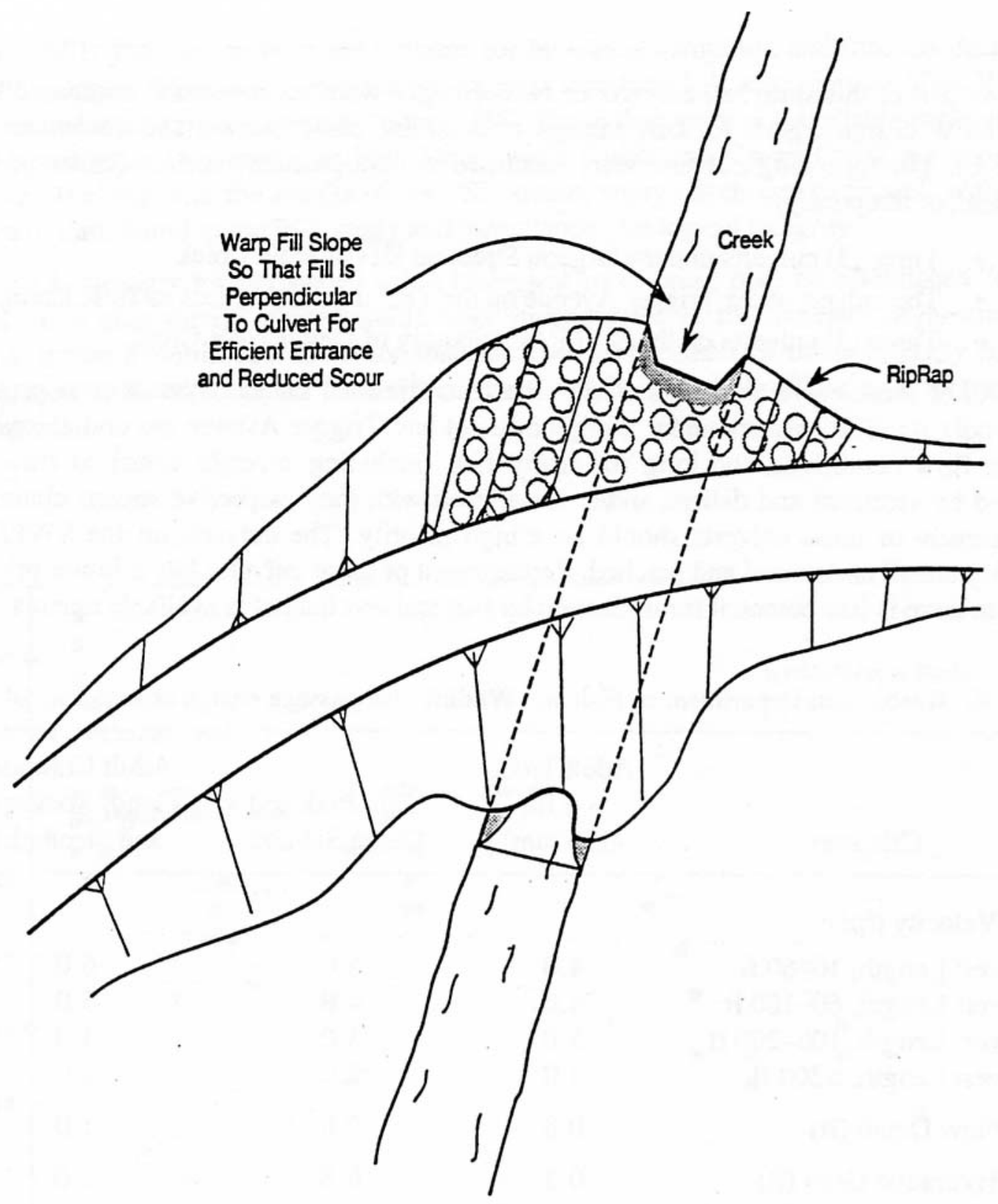

Figure 57. Culvert replacement options (WDFW 1999). 


\section{Option 1: Downstream Grade Control}

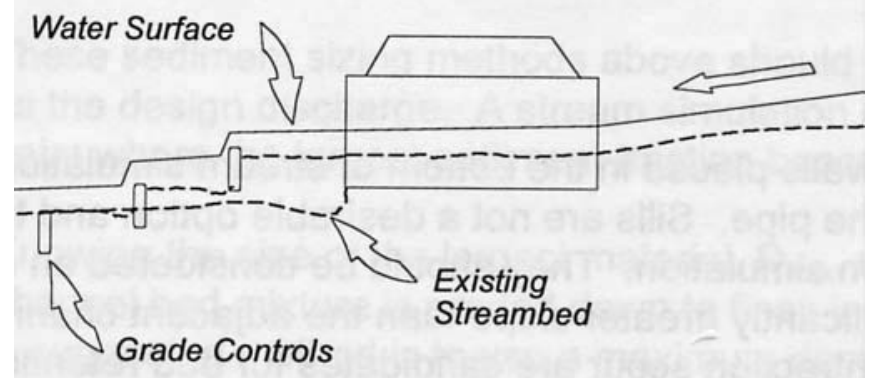

Option 2: Upstream regrade

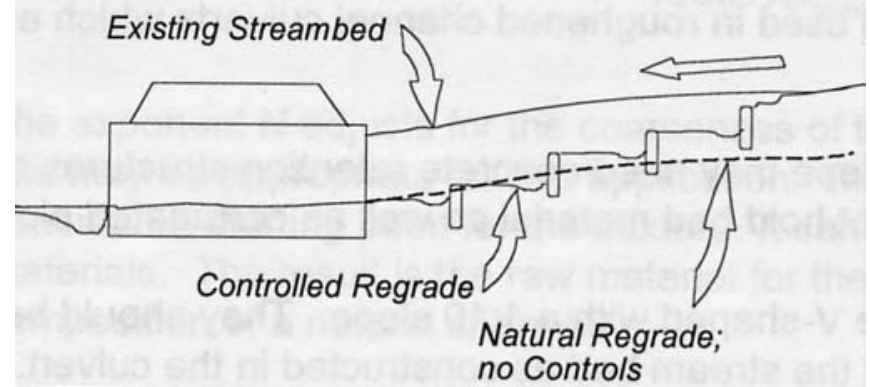

Figure 58. Culvert with grade-control weirs (WDFW 1999). 

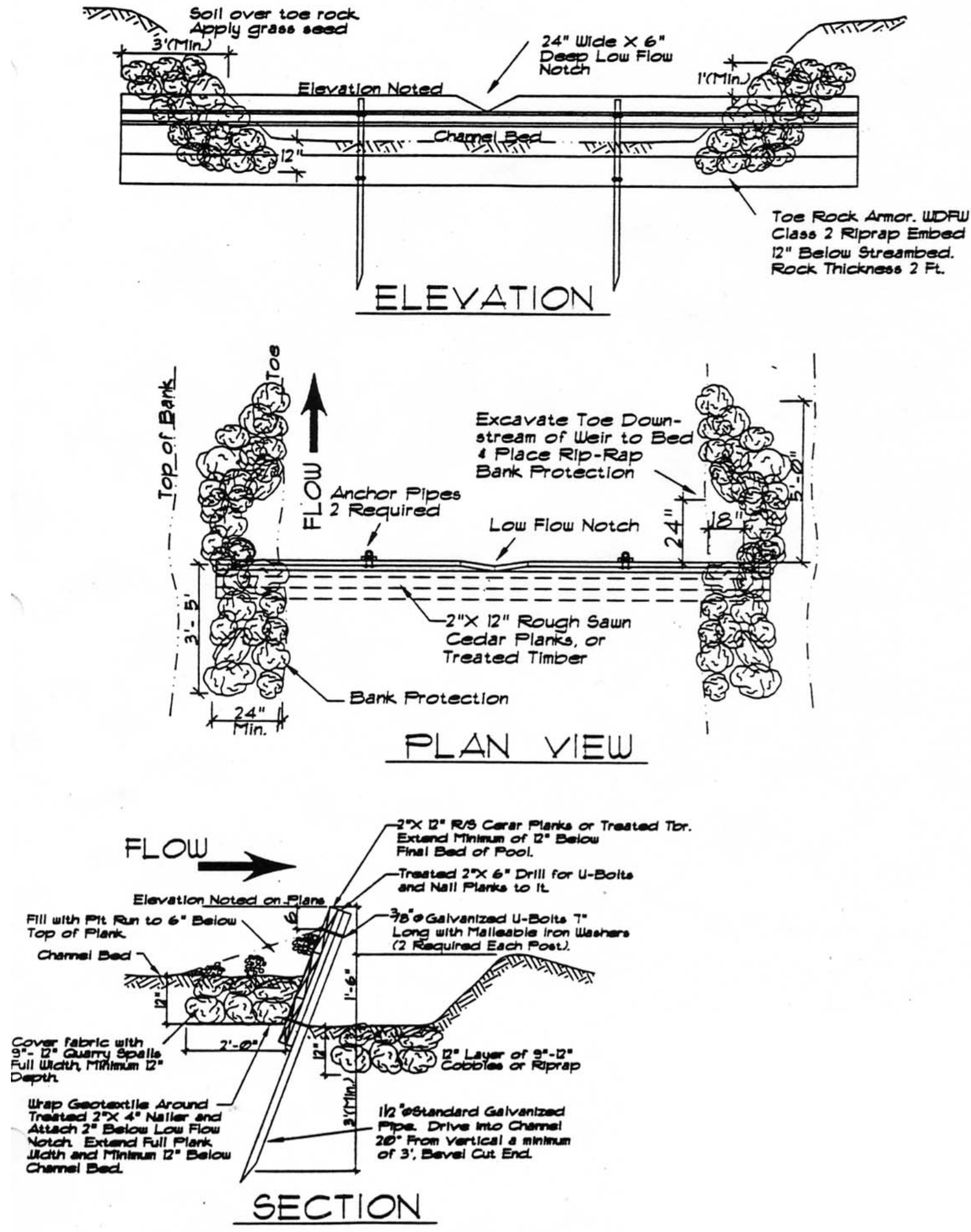

Figure 59. Grade-control weirs (WDFW 1999). 

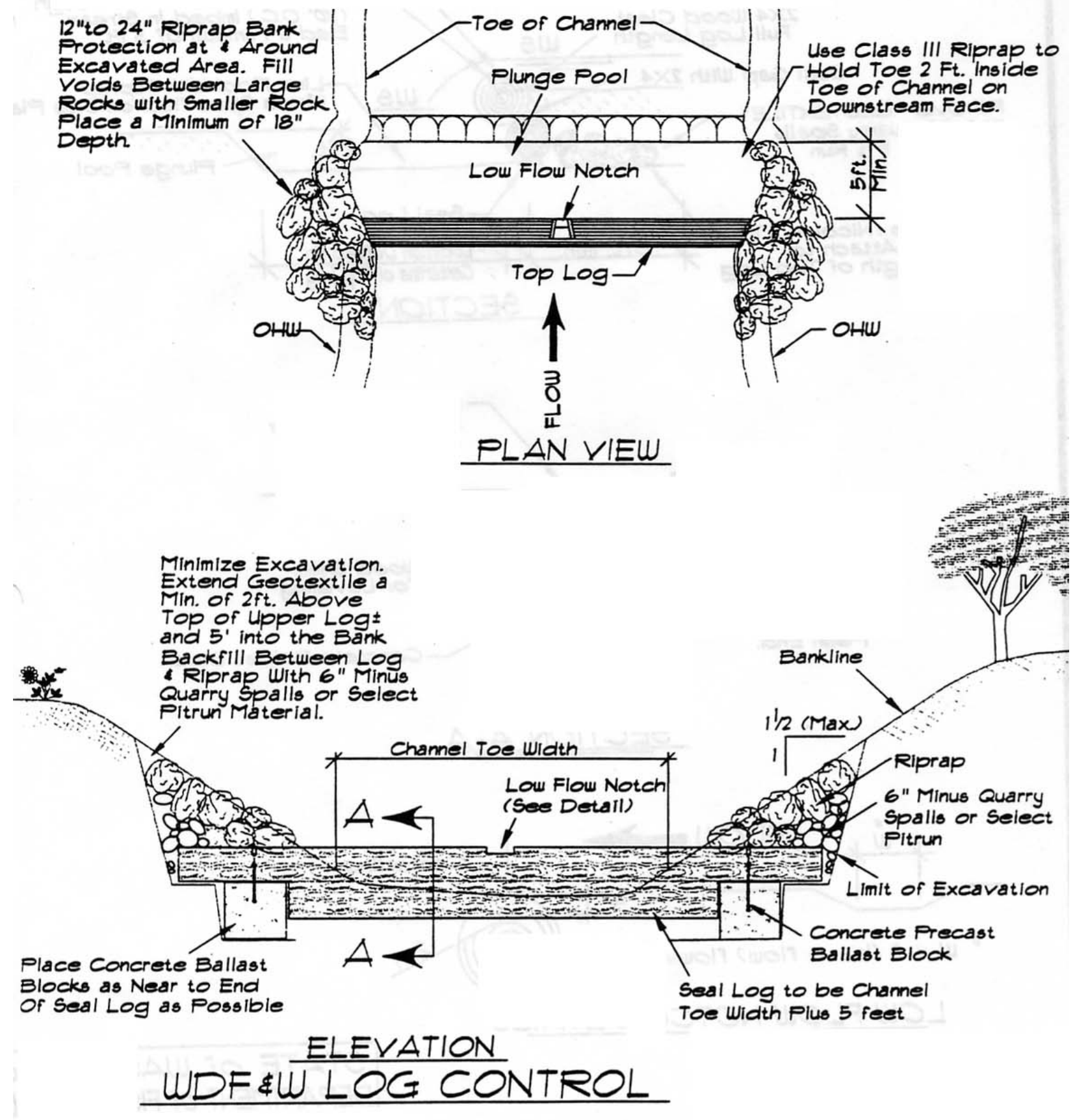

Figure 60. Grade-control weirs (WDFW 1999). 

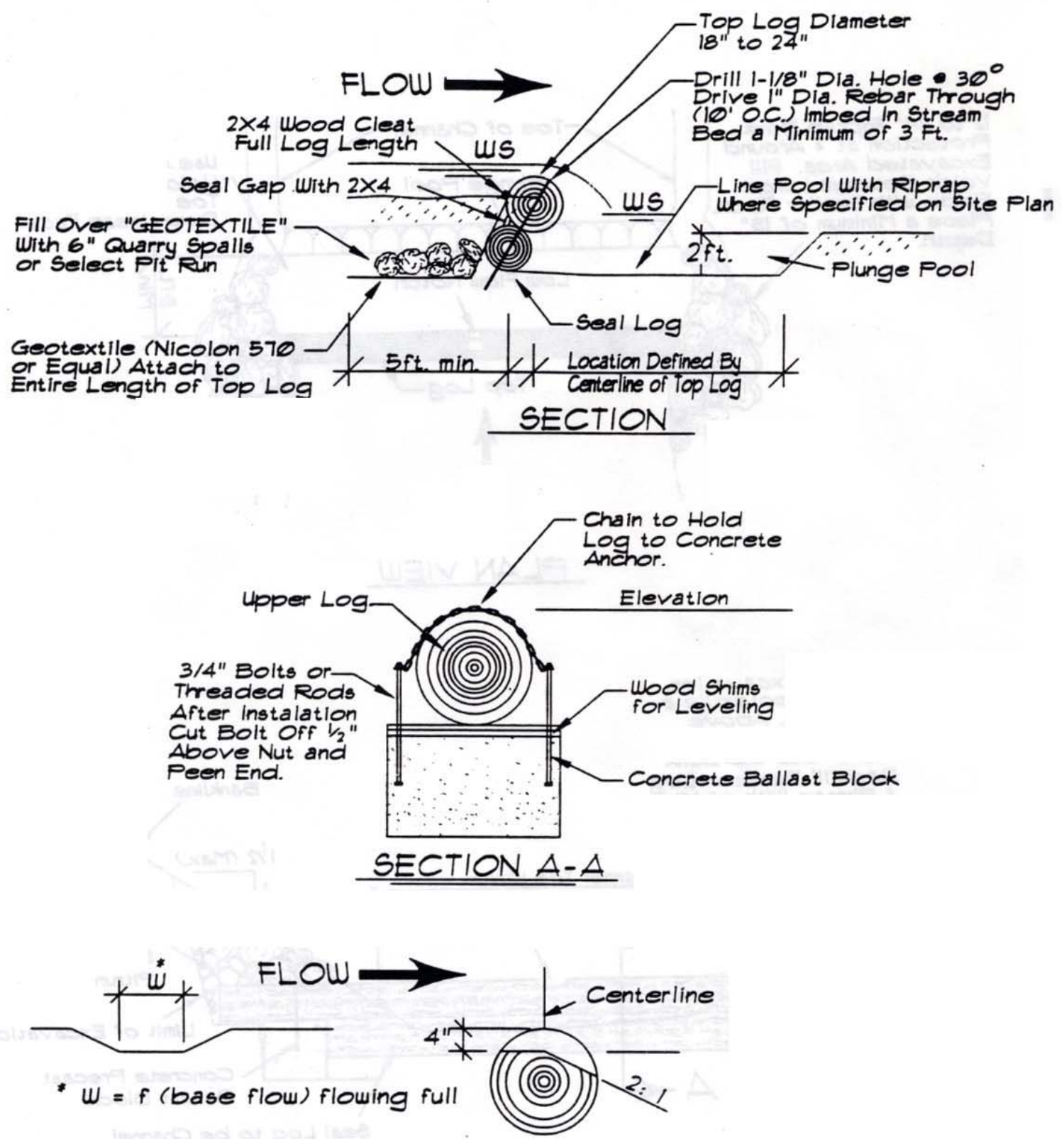

LOW FLOW NOTCH DETAILS

\section{$029 D^{2} \times(2 L-10)=$ Concrete Anchor Volume \\ 2 Needed at each end, (Cubic Feet). \\ Where: \\ $D=$ Dlameter of $\mathrm{Log}$ in Feet \\ $L=$ Length of $\mathrm{Log}$ in Feet.}

Figure 61. Grade-control weirs (WDFW 1999). 
Table 6. Navy Railroad Culvert Corrective Action Summary (in order of priority ranking based on PI score and cost-benefit assessment)

\begin{tabular}{|c|c|c|c|c|c|}
\hline $\begin{array}{l}\text { Culvert } \\
\text { MP }\end{array}$ & Creek & Barrier Status & PI Score & Corrective Action & $\begin{array}{c}\text { Cost } \\
\text { Estimate }\end{array}$ \\
\hline 31.55 & Gorst & Passable & N/A & Remove Debris and inspect culvert & $\$$ \\
\hline 0.71 & Heinz & Partial & 9.79 & Modify (Fishway) or Replace & $\$ \$ \$$ \\
\hline 28.24 & Union & Complete & 15.32 & Replace & $\$ \$ \$ \$ \$$ \\
\hline 1.04 & Jarstad & Complete & 10.17 & Replace & $\$ \$ \$$ \\
\hline $21.67 *$ & $\begin{array}{l}\text { Lake } \\
\text { Devereaux }\end{array}$ & Complete & 7.34 & Replace & $\$ \$ \$$ \\
\hline 12.73 & Deer & Complete & 8.59 & Replace & $\$ \$ \$ \$$ \\
\hline 14.89 & Deer & Passable & N/A & $\begin{array}{l}\text { Install Beaver Deceiver and } \\
\text { Monitor Passage }\end{array}$ & $\$$ \\
\hline 12.01 & Deer & Passable & 7.45 & $\begin{array}{l}\text { Replace Trash Rack with Beaver } \\
\text { Deceiver and Monitor Passage }\end{array}$ & $\$$ \\
\hline 13.10 & Deer & Passable & 8.16 & $\begin{array}{l}\text { Remove Trash Rack and Monitor } \\
\text { Passage }\end{array}$ & $\$$ \\
\hline 8.90 & Deer & Passable & 7.32 & $\begin{array}{l}\text { Remove Trash Rack and Monitor } \\
\text { Passage }\end{array}$ & $\$$ \\
\hline 9.28 & Deer & Passable & 7.12 & $\begin{array}{l}\text { Remove Trash Rack and Monitor } \\
\text { Passage }\end{array}$ & $\$$ \\
\hline 10.50 & Deer & Passable & 6.55 & $\begin{array}{l}\text { Install Beaver Deceiver and } \\
\text { Monitor Passage }\end{array}$ & $\$$ \\
\hline 32.09 & Gorst & Complete & N/A & Replace & $\$ \$ \$ \$ \$$ \\
\hline 2.19 & Unnamed & Complete & 6.43 & $\begin{array}{l}\text { Remove Trash Rack and Replace } \\
\text { Culvert }\end{array}$ & $\$ \$ \$$ \\
\hline 3.79 & Johns & Passable & N/A & Monitor Passage & N/A \\
\hline 6.60 & Cranberry & Passable & N/A & Monitor Passage & N/A \\
\hline 7.52 & Cranberry & Passable & 6.73 & Monitor Passage & N/A \\
\hline 28.48 & Union & Passable & N/A & Monitor Passage & N/A \\
\hline 30.87 & Gorst & Passable & N/A & Monitor Passage & N/A \\
\hline 17.84 & Sherwood & N/A & N/A & Remove Trash Rack & $\$$ \\
\hline 17.96 & Sherwood & N/A & N/A & Remove Trash Rack & $\$$ \\
\hline
\end{tabular}

$\$=$ Low Cost $(<\$ 10 \mathrm{~K})$

$\$ \$=$ Moderate Cost $(<\$ 50 \mathrm{~K})$

$\$ \$ \$=$ Medium-High Cost $(<\$ 100 \mathrm{~K})$

$\$ \$ \$ \$=$ High Cost $(<\$ 500 \mathrm{~K})$

$\$ \$ \$ \$$ = Very High Cost $(>\$ 500 \mathrm{~K})$ 
Railroad Culvert Report

Puget Sound Naval Shipyard and Intermediate Maintenance Facility 


\subsection{REFERENCES}

Baker, C.O. and F.E. Votapka. 1990. Fish Passage through Culverts. Federal Highway Administration and U.S. Forest Service Report FHWA-FL-90-006.

Evans, W.A. and B.A. Johnston. 1980. Fish Migration and Fish Passage: A Practical Guide to Solving Fish Passage Problems. U.S. Forest Service Report USFS-EM-71000-2.

Kahler, T.H. and T.P. Quinn. 1998. Juvenile and Resident Salmonid Movement and Passage Through Culverts. University of Washington Fisheries Research Institute Report T9903-96. Washington State Transportation Center and Washington Department of Transportation Research Report.

WAC (Washington Administrative Code). 1999. "Department of Fish and Wildlife; Hydraulic Code Rules; Water Crossing Structures." WAC 220-110-070, Olympia, Washington.

WCC (Washington Conservation Commission). 2000. WRIA-15 Limiting Factors Analysis (LFA).

WCC (Washington Conservation Commission). 2002. WRIA-14 Limiting Factors Analysis (LFA).

WDFW (Washington Department of Fish and Wildlife). 1999. Fish Passage Design at Road Culverts.

WDFW (Washington Department of Fish and Wildlife). 2000. Fish Passage Barrier and Surface Water Diversion Screening Assessment and Prioritization Manual. 